\title{
The Transition from Hunting-Gathering to Food Production in the Gamo Highlands of Southern Ethiopia
}

\author{
John W. Arthur • Matthew C. Curtis - Kathryn J. W. Arthur • Mauro Coltorti • \\ Pierluigi Pieruccini • Joséphine Lesur • Dorian Fuller • Leilani Lucas • \\ Lawrence Conyers • Jay Stock • Sean Stretton • Robert H. Tykot
}

Published online: 7 March 2019

(C) The Author(s) 2019, corrected publication June/2019

\begin{abstract}
Over three field seasons between 2007 and 2012, we excavated three caves-Mota, Tuwatey, and Gulo - situated at an average elevation of 2,084 $\mathrm{m}$ above sea level in the cool and moist Boreda Gamo Highlands of southwestern Ethiopia. Anthropogenic deposits in these caves date from the Middle to Late Holocene (ca. 6000
\end{abstract}

J. W. Arthur $(\triangle) \cdot$ K. J. W. Arthur

Department of Society, Culture, and Language, University of South Florida St. Petersburg, 140 7th Avenue South, St. Petersburg, FL 33713, USA

e-mail: arthurj@mail.usf.edu

K. J. W. Arthur

e-mail: kjarthur@mail.usf.edu

M. C. Curtis

UCLA Extension, 1145 Gayley Avenue, Los Angeles, CA 90024, USA

e-mail: mccurtis@ucla.edu

M. Coltorti

Dipartimento di Scienze della Terra, Universita di Siena, Siena, Italy

e-mail: maurocoltorti@gmail.com

P. Pieruccini

Dipartimento di Scienze della Terra, Università di Torino, Turin, Italy

e-mail: pieruccinip@gmail.com

\section{J. Lesur}

Museum National d'Histoire Naturelle, CNRS, Paris, France

e-mail: jolesur@mnhn.fr to $100 \mathrm{BP}$ ) and provide excellent preservation of material culture, fauna, flora, and human skeletal remains from which to investigate changes in technologies and habitat use over the last several thousand years. Here, we present results and interpretations, suggesting ways in which Holocene communities of the Boreda Gamo Highlands

D. Fuller

Institute of Archaeology, University College London, London, UK e-mail: d.fuller@ucl.ac.uk

L. Lucas

Anthropology Program, College of Southern Nevada, Las Vegas, NV, USA

e-mail: lei.m.lucas@gmail.com

L. Conyers

Department of Anthropology, University of Denver, Denver, CO, USA

e-mail: lconyers@du.edu

J. Stock

Department of Archaeology, University of Cambridge,

Cambridge, UK

e-mail: jts34@cam.ac.uk

\section{S. Stretton}

Department of Anthropology, University of Illinois at

Urbana-Champaign, Champaign, IL, USA

e-mail: scstret@yahoo.com

\section{R. H. Tykot}

Department of Anthropology, University of South Florida, Tampa, FL, USA

e-mail: rtykot@usf.edu 
constructed new landscapes and technologies in their transition from hunting and gathering to an agropastoral way of life.

Résumé Entre 2007 et 2012, au cours de trois missions de terrain, nous avons fouillé trois grottes-Mota, Tuwatey et Gulo-situées à une altitude moyenne de 2154 mètres au dessus du niveau de la mer. Sur le haut plateau au climat froid et humide de Boreda Gamo, dans le sud-ouest de l'Éthiopie. Les gisements anthropiques dans ces grottes datent de l'Holocène moyen à tardif (environ 6000 à $100 \mathrm{BP}$ ) et présentent une excellente conservation de la culture matérielle, de la faune, de la flore et des restes humains, à partir desquels ont pu être étudiés les changements technologiques et dans les modes d'occpation au cours des derniers millénaires. Nous présentons ici les résultats et les interprétations, proposant les modalitiés par lesquelles les communautés holocènes des hauts plateau du Boreda Gamo ont construit de nouveaux paysages et technologies pour passer de la chasse et de la cueillette à un mode de vie agropastoral.

Keywords Ethiopia - Gamo - Later Stone Age - Cave archaeology $\cdot$ Hunter and gatherer $\cdot$ Food production

\section{Archaeological Identification of Food Production in the Horn of Africa}

The Horn of Africa has long been recognized as a major center of plant domestication and an important region for the advent and development of pastoralism in Africa (Brandt 1984; Clark 1980; Curtis 2013; D’Andrea et al. 1999; Fuller and Hildebrand 2013; Fuller et al. 2014; Harlan 1969, 1971, 1992; Lesur et al. 2014a; Phillipson 1993; Portères 1976; Purugganan and Fuller 2009; Vavilov 1950; Westphal 1975). However, one of the unique aspects of the Horn and specifically Ethiopia is the relatively late domestication of animals and plants compared to the adjacent regions of South Arabia and the Nile Valley (Harrower et al. 2010). Current archaeological evidence for farming in the Horn, in the form of agropastoralism, dates to the third millennium BP (Bard et al. 1997; Boardman 1999; Brandt 1984; Brandt and Carder 1987; Clark 1988; Clark and Prince 1978; Clark and Williams 1978; Curtis 2013; D'Andrea 2008; D'Andrea et al. 1999, 2008a; Gutherz et al. 2015; Harrower et al. 2010; Lesur et al. 2007, 2014b; Marshall and
Hildebrand 2002; Negash 2001; Phillipson et al. 2000; Schmidt and Curtis 2001).

Within the Horn of Africa, northern Ethiopia and Eritrea have yielded the most comprehensive evidence for ancient African plant domestication, with domesticated teff (Eragrostis tef) and finger millet (Eleusine coracana) dating to the third and second millennium BP, respectively (D'Andrea 2008; D'Andrea et al. 2008a, b; Marshall and Weissbrod 2011). However, the ancient Ethiopian communities may have originally relied on Western Asian cultivars such as emmer (Triticum dicoccum) and bread wheat (Triticum aestivum), barley (Hordeum vulgare), lentils (Lens esculentus), and linseed/flax (Linum usitatissimum) (Beldados et al. 2015; D'Andrea et al. 1999; Curtis 2013; Fuller et al. 2014). Macrobotanical evidence for these domesticates is found in northern Ethiopia at Pre-Aksumite sites and in Eritrea at Ancient Ona Culture sites dating to the early third millennium BP (Bard et al. 1997; Boardman 1999; Curtis 2013; D'Andrea 2008; D'Andrea et al. 2008a). The highlands of the Horn of Africa are unique on the continent for the ancient cocultivation of African and Near Eastern crops, but the relative contribution of each to the overall regional diet and economic system varied (D'Andrea et al. 2011; Phillipson et al. 2000). For example, the stable isotope analysis of a human burial dated to 1600 BP from the Tigray region of northern Ethiopia indicates that the individual depended on a plant-based diet centered on Near Eastern $\mathrm{C}_{3}$ plants with a lesser reliance on African $\mathrm{C}_{4}$ plant material (D'Andrea et al. 2011). However, one cannot generalize based on this single individual.

Today, the food production systems of southwestern Ethiopia are significantly different from that of northern Ethiopia. Populations in the southern highlands tend domesticated animals and grow a mixture of Near Eastern and African grain crops, and they rely upon root crops and enset (Ensete ventricosum) more than northern populations. Enset is an endemic domesticate that provides a nutritious starchy food. It is grown in small areas with terracing, is both drought- and pest-resistant, and has a widespread and probably very ancient presence in food production traditions (Brandt et al. 1997; Curtis 2013; Hildebrand 2007). Pastoralism and farming occurred much later in southern Ethiopia than in northern Ethiopia and other regions of eastern Africa as suggested by preliminary excavations at rockshelter and caves in Wolayta (Asmare 2015; Barnett 1999; Gutherz et al. 2002; Lesur et al. 2007), Kafa (Hildebrand et al. 2010), and the Gamo region (Arthur 
et al. 2009, 2010). At Kumali rockshelter in Kafa, Hildebrand et al. (2010) found extensive quantities of desiccated plant material that date after $1740 \mathrm{BP}$, which may be wild enset, domesticated enset (Ensete ventricosum), or possibly domesticated banana (Musa spp.), suggesting early reliance on vegeculture. Enset cultivation is often associated with Omotic-speaking populations, and some linguists suggest that Omotic speakers may have originated in southwestern Ethiopia and may have begun collecting enset ca. 10,000 years ago (Bender 1988, p. 152; Blench 2006, p. 150-152, 159-160; Blench and Dendo 2008; Blench and MacDonald 2006, p. 346, 359, 457-459).

As with the advent of domesticated plants, our knowledge of when pastoralism was adopted in southern Ethiopia is dependent on a small number of investigated sites (see Hildebrand et al. 2010; Lesur et al. 2007). At Mochena Borago, the most thoroughly excavated rockshelter in southern Ethiopia, located just $50 \mathrm{~km}$ to the north of Boreda Gamo, there is no evidence of domesticated animals in the Holocene strata dating from 7000 to $1000 \mathrm{cal}$ BP (Lesur et al. 2007). The majority of the faunal remains at Mochena Borago consist of African buffalo (Syncerus caffer) and a wide range of other wild fauna, many of which no longer inhabit the region. Rockshelter sites from the Kafa region, located northwest of the Gamo region, indicate that cattle and caprines date no earlier than $\sim 2000$ BP. This was contemporaneous with the first pottery production in the area (Hildebrand et al. 2010). These dates are much later than the evidence for animal domestication in the areas further south, especially in the Lake Turkana region, where faunal evidence reveals that cattle and goats were added to an already established broad spectrum hunter-gatherer economy when the climate was transitioning from a humid to a dry period ca. 4200 BP (Ashley et al. 2011; Barthelme 1984; Marshall et al. 1984; Robbins 1984, 2006). Various factors are proposed to explain the late adoption of pastoralism in southwest Ethiopia, including heavy rainfall, dramatic topography, dense forests, and a reliance on perennial plants, such as enset and yams (Hildebrand and Grillo 2012; Lesur et al. 2014a).

In this article, we add to the nascent understanding of food production in southwestern Ethiopia based on the research findings at three cave sites-Mota, Tuwatey, and Gulo, in the Gamo region. The archaeological evidence from these caves, dating from the Middle to Late Holocene (ca. 6000 to $100 \mathrm{BP}$ ), reveal a classic Later Stone Age lithic assemblage, the inception of pottery, the transition from wild to domesticated fauna and flora, and a burial with a complete ancient African human genome. The cultural changes demonstrated in the archaeological record offer new perspectives concerning human use of highland landscapes in southwestern Ethiopia over the last 6,000 years.

The Gamo region of southern Ethiopia is diverse with elevations ranging from 1,200 $\mathrm{m}$ along the Rift Valley lakes of Abaya and Chamo to 4,000 $\mathrm{m}$ in the highlands. The contemporary Gamo human population numbers over one million and the region's agricultural production is dependent on a bimodal rainfall pattern (Wana and Woldu 2006). The populations live at a variety of altitudinal zones and consume different types of grains, domesticated animals, dairy products, and tubers, in part, based on access to resources stratified across the different ecozones of the region. Indigenous cultivars of Ethiopia are grown alongside crops of western Asian origin, as well as those of wider tropical Africa, the Americas, and greater Eurasia (see Samberg et al. 2010). The relatively high rainfall and steep gradients affect the integrity of open-air archaeological site deposits in this region. However, caves are protected from significant alluvial disturbance, providing excellent locales for the preservation of ecofacts and material culture in anthropogenic deposits. Between 2005 and 2012, we began our study of the Gamo landscape by working with the Boreda community to identify, locate, map, and test sites, including cave sites in the northern Gamo Highlands, $\sim 2,154 \mathrm{~m}$ above sea level (Arthur et al. 2017). In our collaboration with the Boreda community, particularly elders, they revealed to us the presence of Mota Cave, Tuwatey Cave, and Gulo Cave, each possessing substantial anthropogenic deposits (Fig. 1). Favorable taphonomic conditions in these caves have permitted a good preservation of material culture, fauna, and flora that allow us to investigate the long-term development of hunter-gatherer and food production adaptations, as well as changes in technologies and habitat use.

Mota, Tuwatey, and Gulo caves are situated in columnar basalt formations behind waterfalls, which drain over and in front of each cave. The splash erosion at the foot of the waterfall over each cave affects the softer layers of sediments, generating an overhanging wall that is prone to collapse. The debris cone caused by the collapse often diverted water to the inner part of the cave thereby enlarging it (Fig. 2). In Tuwatey Cave, for example, there is a thick layer of mud created from the diversion of the water back into the cave that allowed a small pond to form for a time during the early part of the 
Fig. 1 Map showing the location of the Gamo region and the caves within Ethiopia

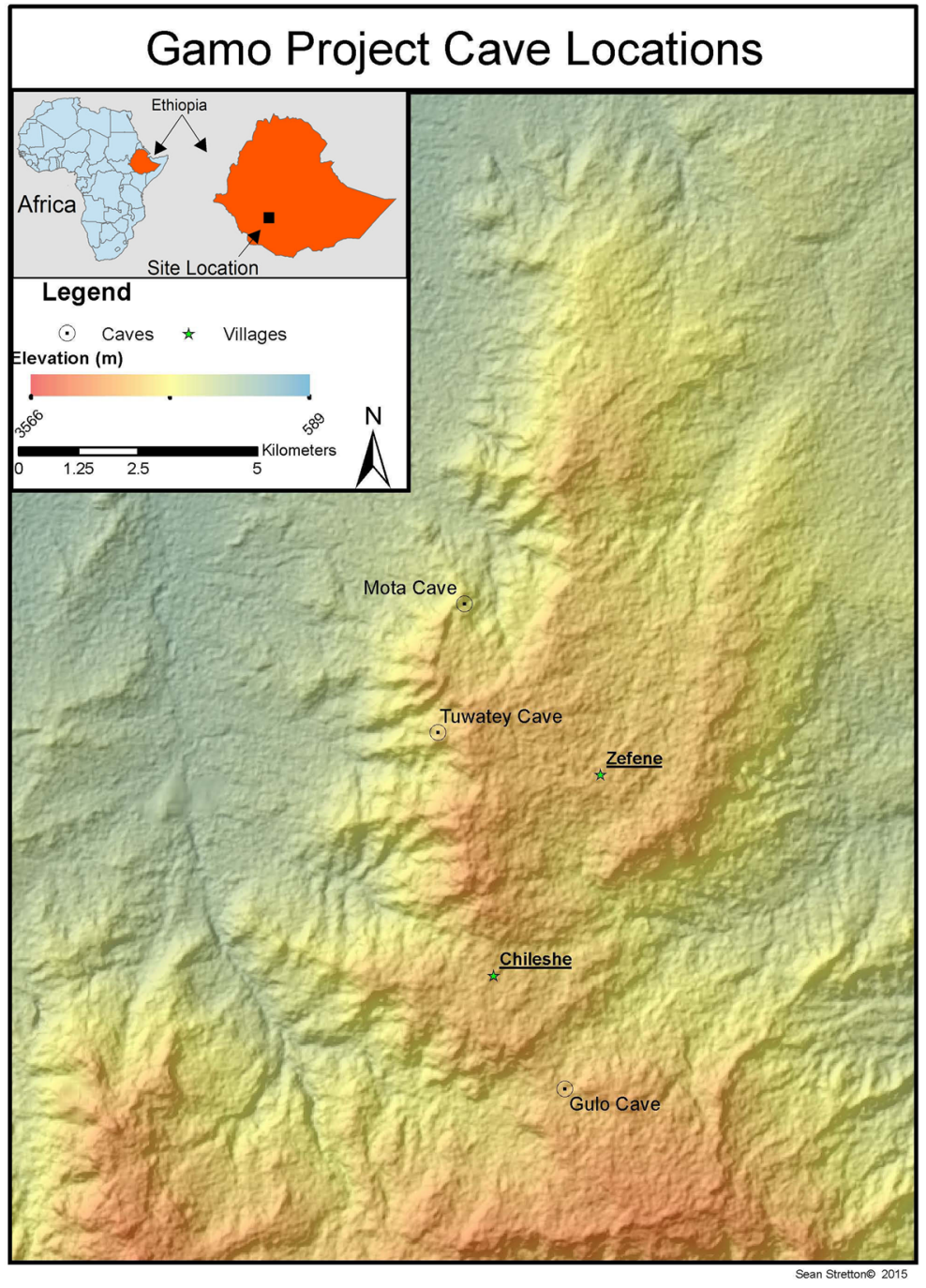

Historic period, ca. 300-200 BP. In Mota Cave, there was once an underground stream that ran below the current cave deposits as evidenced by the presence of rounded and subrounded gravels resting directly on the basalt bedrock. During the early formation of the caves, prior to human occupation, rounded and subrounded gravels were deposited, upon which both natural and anthropogenic deposits accumulated during the Middle and Later Holocene, forming a complex stratigraphy that spans more than 6,000 years.

\section{Mota Cave (Site GB20)}

The Mota Cave deposits indicate human activity since the fifth millennium BP (Table 1). The cave is situated $1,963 \mathrm{~m}$ above sea level on the western escarpment of the northern Boreda Gamo Highlands (Fig. 3). The cave was documented in 2011 in collaboration with local Boreda elders and was partially excavated in 2012. Our local guides identified the site as Mota Gongola (Mota Cave), but later an elderly woman revealed a second name for the site, Sorsha Gongola or the Snake Spirit Cave. According to her, the site played an important role in the local religious practices. It was in this cave that her husband would make barley powder and sheep's blood offerings to the snake spirit, Sorsha, a practice meant for the spiritual and physical wellness of the community.

The cave measures $14 \mathrm{~m}$ in width and $9 \mathrm{~m}$ in depth and has a large area of rock fall in the center of the floor. Rounded gravels are at the bottom of the cave deposit indicating intensive fluvial erosion when the cave was formed. Excavations, including one shovel test unit and 
Fig. 2 Four stages in the formation of the Gamo caves
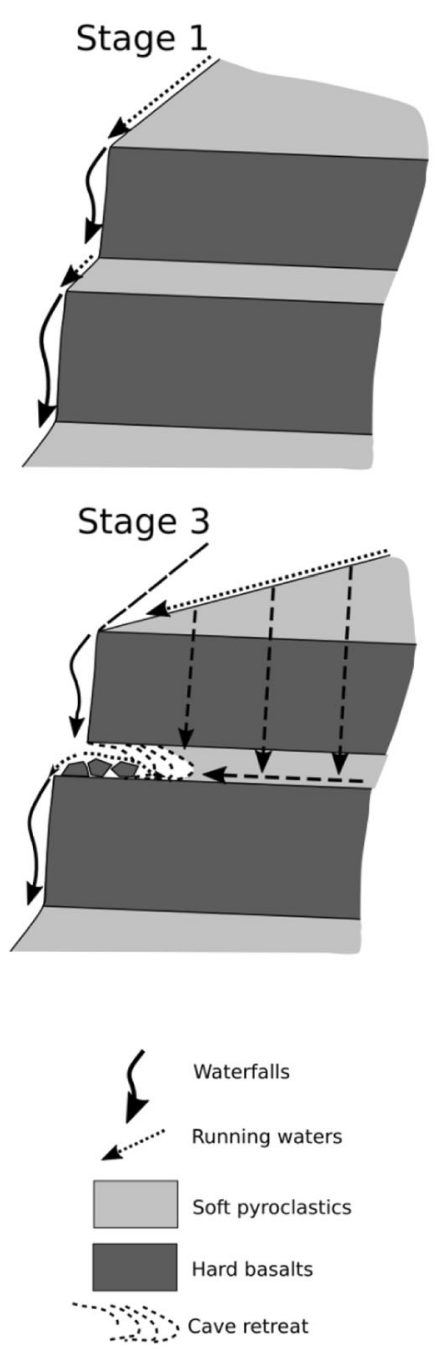
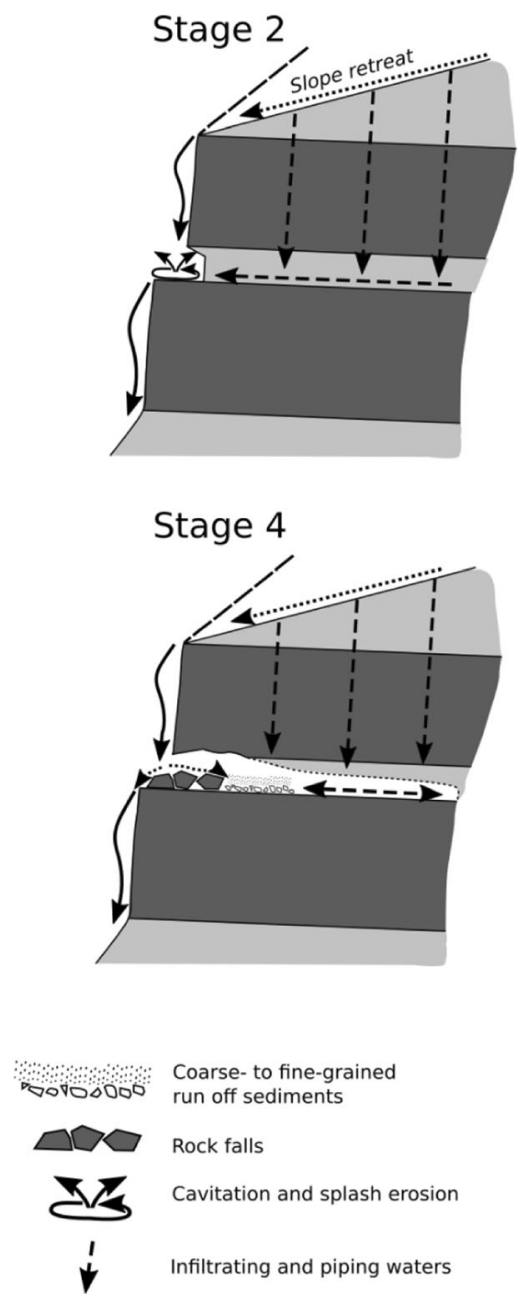

four excavated units toward the mouth of the cave (1, 3, 5,6 , and 7) and a second test unit and one excavated unit ( 2 and 4 ) in the back of the cave, reveal multiple anthropogenic layers (Fig. 4). The east wall (Table 2 and Fig. 5) and west wall (Table 3 and Fig. 6) of units 3 and 5 have nine different sediment layers with one hearth and revealed one human burial with a cairn. The hearth present in unit 5 extends into adjacent unit 1 , level 4. The burial in unit 3 extends into units 5, 6, and 7. Unit 4 consists of 16 sediment layers (Table 4 and Fig. 7) and includes a second hearth feature (L3-6, stratigraphic layers 3 to 11). Unit 2 adjacent to unit 4 consists of a separate third hearth feature (L3-4). The radiocarbon dates obtained from 11 organic samples from these units date from 4520 to 300 cal BP (Table 1). Three broad time ranges are represented: Pre-Pottery period: 4520-3340 cal BP (a burial and a hearth), Early Pottery period: $2370-1620$ cal BP (two hearths), and Historic period: 330 cal BP to $300 \mathrm{BP}$ (possible hearth).

Pre-Pottery Period and Earliest Occupation (4520 to 3340 Cal BP)

The first inhabitants to occupy Mota Cave were PrePottery hunters, gatherers, and fisher people who were utilizing the lowland lakes but living in the highlands, where they prepared their obsidian tools, cooked their food, and buried their dead. No botanical remains have been recovered during this time span. Evidence of their earliest subsistence is a tilapia fishbone with an associated date of $4520 \mathrm{cal} \mathrm{BP}$. This is a clear indication that people were fishing in, or acquiring fish through some forms of exchange from, Lake Abaya or Lake Chamo in 
Table 1 Radiocarbon dates from Boreda Gamo Cave excavations

\begin{tabular}{|c|c|c|c|c|c|c|c|c|}
\hline Lab no. & Site & Unit:level:cm bs & $14 \mathrm{C} \mathrm{BP}$ & $\mathrm{d} 13 \mathrm{C}(\% o)$ & Cal BP & $95 \%$ range $\mathrm{BP}$ & Recovery method & Dating type \\
\hline Beta-405537 & Mota Cave & $5: 6: 40-50$ & $4480 \pm 30$ & -27.2 & $4520 \pm 30$ & $5295-4975$ & Sieve & AMS \\
\hline OxA-29631 & Mota Cave & $5: 7: 50$ & $3997 \pm 29$ & -14.5 & - & $4524-4418$ & In situ & AMS \\
\hline Beta-331419 & Mota Cave & $4: 5: 40-50$ & $4030 \pm 30$ & -24.0 & $4050 \pm 30$ & $4780-4440$ & Sieve & AMS \\
\hline Beta-331422 & Mota Cave & $5: 7: 50$ & $3620 \pm 30$ & -14.8 & $3790 \pm 30$ & $4240-4090$ & In situ & AMS \\
\hline Beta-331420 & Mota Cave & $4: 6: 50-60$ & $3780 \pm 30$ & -24.8 & $3780 \pm 30$ & $4240-4080$ & Sieve & AMS \\
\hline Beta-331418 & Mota Cave & $4: 4: 31-40$ & $3300 \pm 30$ & -22.4 & $3340 \pm 30$ & $3680-3480$ & Sieve & AMS \\
\hline Beta-405096 & Mota Cave & $2: 3: 20-30$ & $2380 \pm 30$ & -24.5 & $2370 \pm 30$ & $2485-2345$ & Sieve & AMS \\
\hline Beta-405095 & Mota Cave & $2: 2: 10-20$ & $1700 \pm 30$ & -25.1 & $1700 \pm 30$ & $1695-1545$ & Sieve & AMS \\
\hline Beta-331421 & Mota Cave & $5: 4: 24-30$ & $1610 \pm 40$ & -24.5 & $1620 \pm 30$ & $350-540$ & In situ & AMS \\
\hline Beta-405094 & Mota Cave & $3: 2: 10-20$ & $330 \pm 30$ & -24.9 & $330 \pm 30$ & $485-305$ & Sieve & AMS \\
\hline Beta-331417 & Mota Cave & $4: 3: 20-31$ & $310 \pm 30$ & -25.8 & $300 \pm 30$ & $460-300$ & Sieve & AMS \\
\hline Beta-237451 & Tuwatey Cave & 1:8:91-101 & $5500 \pm 40$ & -23.9 & $5520 \pm 40$ & $6400-6280$ & Sieve & AMS \\
\hline Beta-405091 & Tuwatey Cave & $C 7: 7: 60-63$ & $5280 \pm 30$ & -25.1 & $5280 \pm 30$ & $6180-5945$ & In situ & AMS \\
\hline Beta-405097 & Tuwatey Cave & J5:7:60-73 & $5020 \pm 30$ & -24.8 & $5030 \pm 30$ & $5895-5660$ & In situ & AMS \\
\hline Beta-237453 & Tuwatey Cave & 2:9:99-110 & $4380 \pm 40$ & -22.2 & $4430 \pm 40$ & $5280-4870$ & Sieve & AMS \\
\hline Beta-237454 & Tuwatey Cave & $2: 10: 110-120$ & $4310 \pm 40$ & -24.0 & $4330 \pm 40$ & $4970-4840$ & Sieve & AMS \\
\hline Beta-237450 & Tuwatey Cave & 1:7:79-91 & $4420 \pm 40$ & -24.5 & $4420 \pm 40$ & $5280-4870$ & Sieve & AMS \\
\hline Beta-237452 & Tuwatey Cave & $2: 5: 42-54$ & $3230 \pm 50$ & -25.3 & $3230 \pm 50$ & $3570-3360$ & Sieve & AMS \\
\hline Beta-405090 & Tuwatey Cave & M3:6:50-60 & $1900 \pm 30$ & -24.0 & $1920 \pm 30$ & $1925-1820$ & In situ & AMS \\
\hline Beta-405092 & Tuwatey Cave & $\mathrm{O} 2: 8: 71-80$ & $1810 \pm 30$ & -24.1 & $1820 \pm 30$ & $1825-1635$ & In situ & AMS \\
\hline SUERC-61527 & Tuwatey Cave & $C 7: 7: 60-70$ & $492 \pm 29$ & -23.6 & $492 \pm 29$ & $534-500$ & Sieve & $\mathrm{AMS}^{1}$ \\
\hline Beta-405093 & Tuwatey Cave & $1: 3: 30-40$ & $290 \pm 30$ & -24.1 & $300 \pm 30$ & $460-295$ & In situ & AMS \\
\hline SUERC-61528 & Tuwatey Cave & $1: 2 \mathrm{~L}: 10-20$ & $172 \pm 29$ & -22.3 & $172 \pm 29$ & $282-34$ & Sieve & $\mathrm{AMS}^{2}$ \\
\hline SUERC-61529 & Tuwatey Cave & $1: 2 \mathrm{~L}: 10-20$ & $122 \pm 29$ & -21.5 & $122 \pm 29$ & $265-10$ & Sieve & $\mathrm{AMS}^{3}$ \\
\hline Beta-249262 & Gulo Cave & 1:5:80-100 & $5380 \pm 40$ & -25.7 & $5390 \pm 40$ & $6280-6010$ & Sieve & AMS \\
\hline Beta-405084 & Gulo Cave & $1: 1: 20$ & $2260 \pm 30$ & -25.8 & $2250 \pm 30$ & $2345-2155$ & Sieve & AMS \\
\hline Beta-249261 & Gulo Cave & $1: 2: 20-40$ & $2050 \pm 40$ & -26.2 & $2070 \pm 40$ & $2120-1920$ & Sieve & AMS \\
\hline Beta-405086 & Gulo Cave & $1: 4: 60-80$ & $2020 \pm 30$ & -24.3 & $2030 \pm 30$ & 2055-1900 & Sieve & AMS \\
\hline Beta-405085 & Gulo Cave & $1: 3: 40-60$ & $1680 \pm 30$ & -24.6 & $1690 \pm 30$ & $1695-1535$ & Sieve & AMS \\
\hline Beta-405087 & Gulo Cave & $1: 6: 100-115$ & $1690 \pm 30$ & -28.6 & $1630 \pm 30$ & $1570-1415$ & Sieve & AMS \\
\hline
\end{tabular}

\footnotetext{
${ }^{1}$ From carbonized Hordeum vulgare seed

${ }^{2}$ From carbonized Gossypium sp.

${ }^{3}$ From carbonized Hordeum vulgare seed
}

the adjacent Rift Valley lowlands. Connection with the lowlands is also confirmed based on the predominance of obsidian and chert/chalcedony tools. The analysis by portable X-ray fluorescence spectrometry of 65 obsidian pieces from the Pre-Pottery levels of unit 4 indicates procurement mainly from three chemically distinct sources, but their geological locations have not been identified (Fig. 8). A small bit of ochre (unit 5, L6) adjacent to the burial was perhaps used for body ornamentation, and geodes (unit 4, L6) associated with a hearth and another placed under the leg of the interred person indicate mortuary ritual/symbolic activities at the site.

Diet and Technology The faunal remains and the lithics suggest a hunting-gathering way of life and in situ animal processing and microlithic obsidian tool production. The fauna are few for the earliest occupation but indicate people were hunting small to large, wild animals including bovid, klipspringer, suid, monkey, and hare (Table 5). The presence of one tilapia bone also 
Fig. 3 Mota Cave

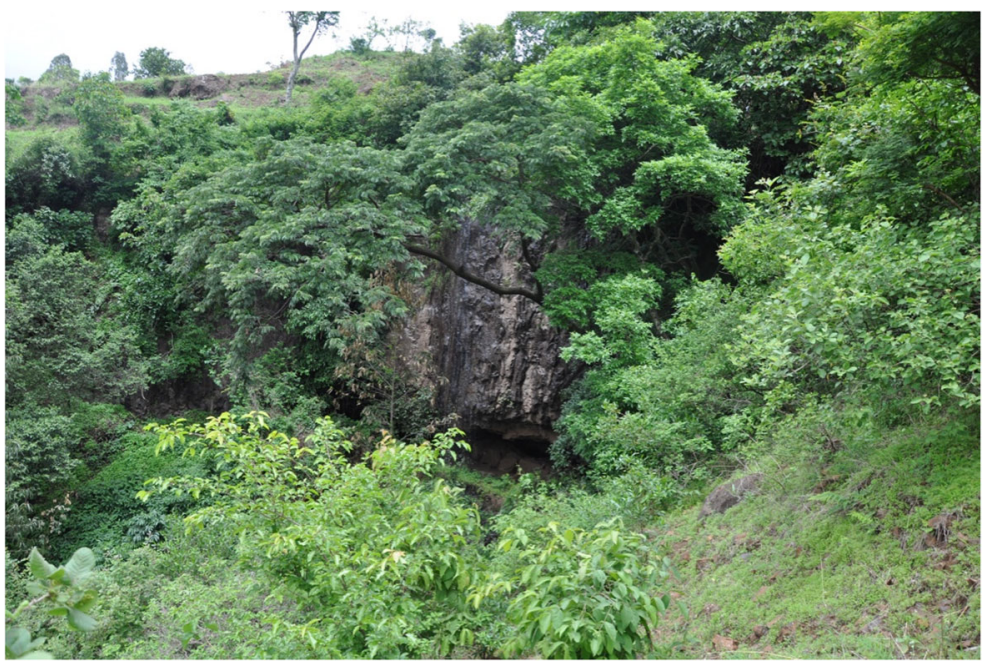

Fig. 4 Plan map of Mota Cave and location of excavation areas

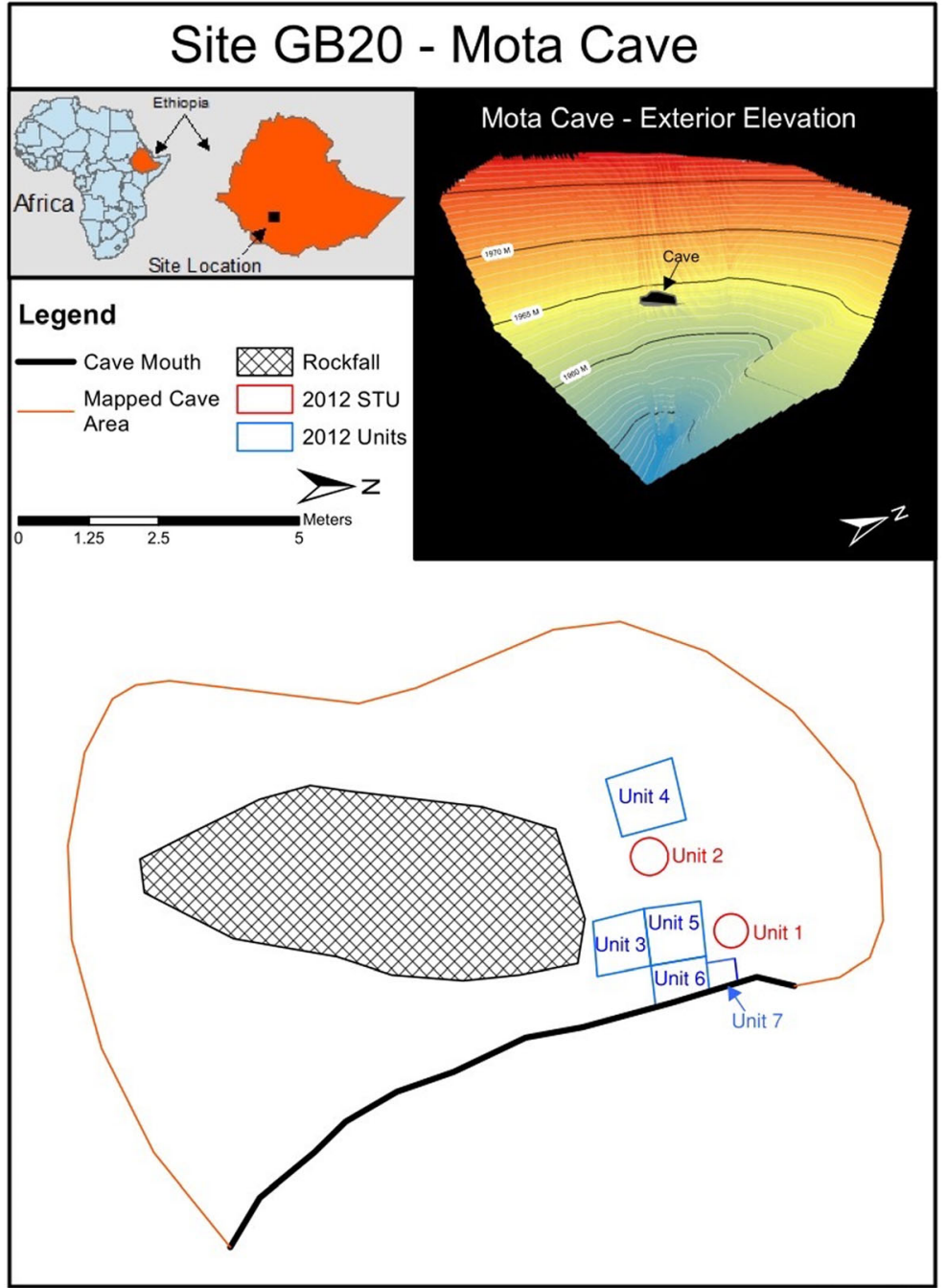


suggests that the occupants of Mota had access to the aquatic resources in the lowlands. The Pre-Pottery period at Mota has a rich lithic assemblage, $20 \%$ of which consists of a wide range of Late Stone Age tools. Lithic materials reinforce the presence of a hunting and gathering technology with unifacial points and likely hafted microlithic tools used for cutting, engraving, sewing, and scraping (Barham 2013).

The cave's occupants produced small tools (Table 6), typical of the microlithic tradition, from primarily obsidian, but there is a small representation of other rock types, such as chert, quartz, and basalt, in the lithic assemblage. The greatest concentration of lithics was associated with the human burial, discussed below, and in unit 4 (Table 6). These hunters and gatherers engaged in hide processing activities with chert and obsidian scrapers (double, side, end, end-side, end double side, circular, convergent, and backed) with edge angles ranging from $47^{\circ}$ to $85^{\circ}$ in various stages of use. Almost one-third of the scrapers exhibited multiple-use edges. This suggests that they likely hafted these tools in open hafts secured with rope rather than mastic so that they could easily remove the scraper and rehaft using another edge. The assemblage also indicated that people sewed hides with awls and engraved with burins. They cut meat and/or cut wild grasses with possibly hafted backed blades made of microlithic geometric tools such as crescents, trapezoids, and triangles with cutting edge angles ranging from $20^{\circ}$ to $48^{\circ}$. Furthermore, they hunted with obsidian triangular, oval, and polygon unifacial points. These are primarily associated with hearths at the site (Fig. 9). Cores, debitage, a hammerstone, and scraper and point preforms indicate that the inhabitants were actively making the tools present in the cave. The early peoples of Mota knapped a range of core sequences including obsidian single platform cores, and pyramidal, radial, and bipolar cores, which resulted in blade (14\%) and flake (86\%) debitage production (Fig. 10). The consistent presence of debitage at Mota Cave throughout the deposit (Tables 7 and 8) demonstrates that individuals were engaged in core reduction and tool production.

Ethnographically, stone tool making is a technology that is transferred through scaffolding from elders to youth beginning when the latter reach puberty (Arthur 2018, p. 227-228). Among all historic and ethnographically documented lithic practitioners, both men and women knapped. Bipolar cores are particularly associated with women in almost all known stone-knapping traditions (Arthur 2010, 2018, p. 208). Therefore, women may have been active toolmakers at Mota. The presence 


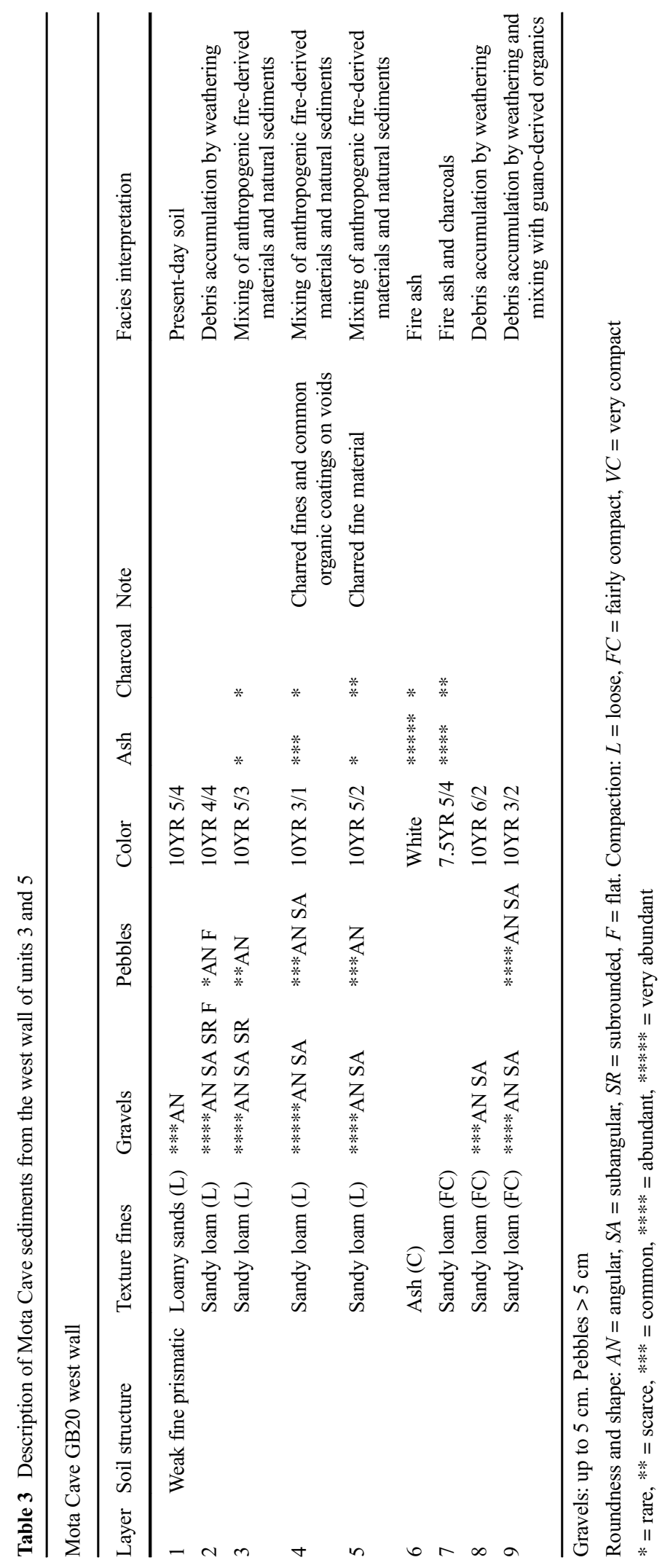




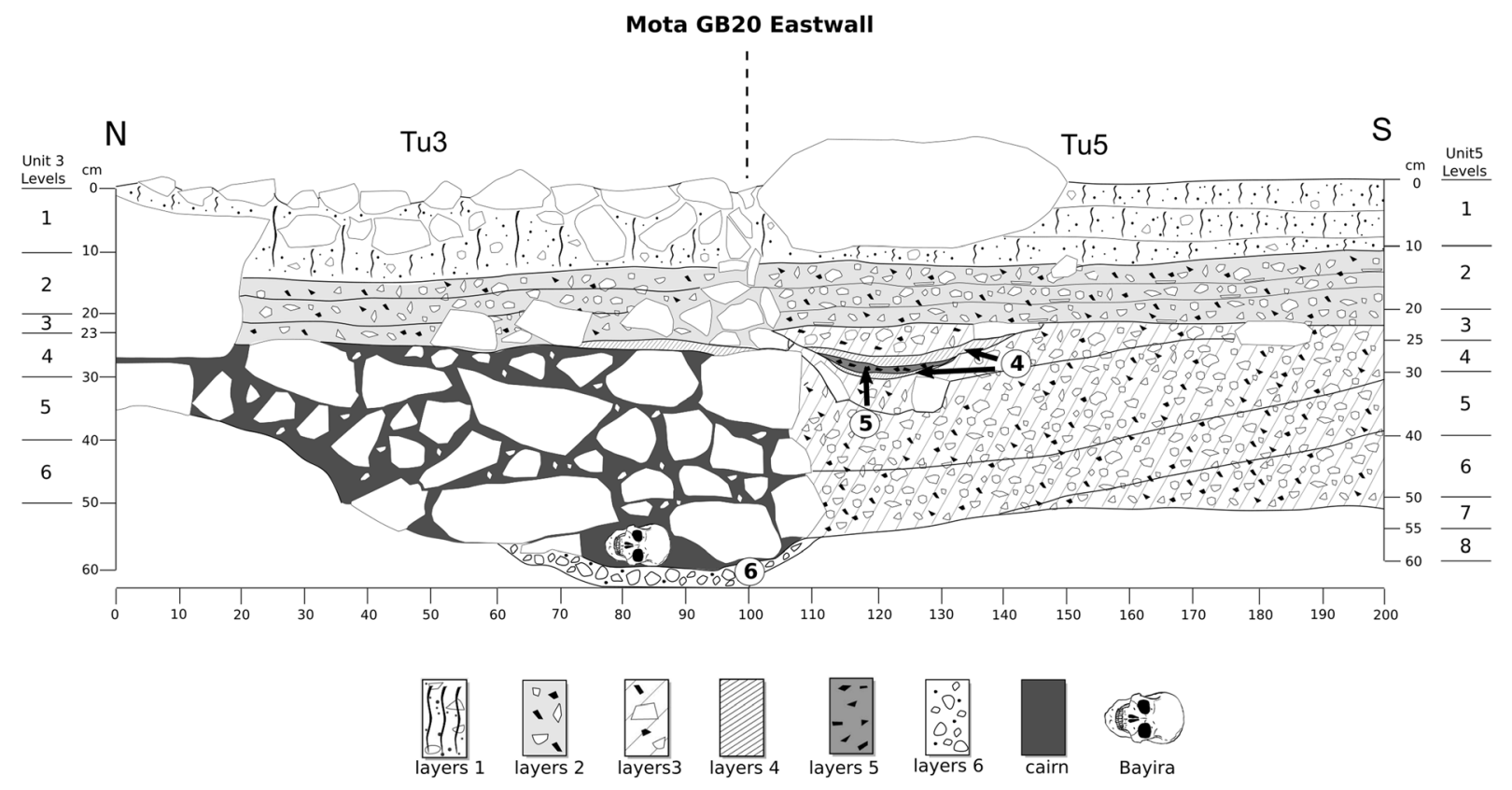

Fig. 5 Mota Cave profile of the eastern wall of units 3 and 5

of a broken core dating to the Pre-Pottery period also may suggest the presence of novice toolmakers. Novices are more likely to break tools during use and to create spurs on scrapers when resharpening during use (Weedman 2002; Arthur 2018, p. 163-169). Fourteen percent of the geometric tools were broken, which suggests novices may have been engaged in cutting meat and/or wild grasses. Nearly $30 \%$ of the Mota scrapers exhibited spurs which, in ethnographic examples of hide processing, would render the tools useless. This would explain why most of the spurred scrapers were discarded in a hearth.

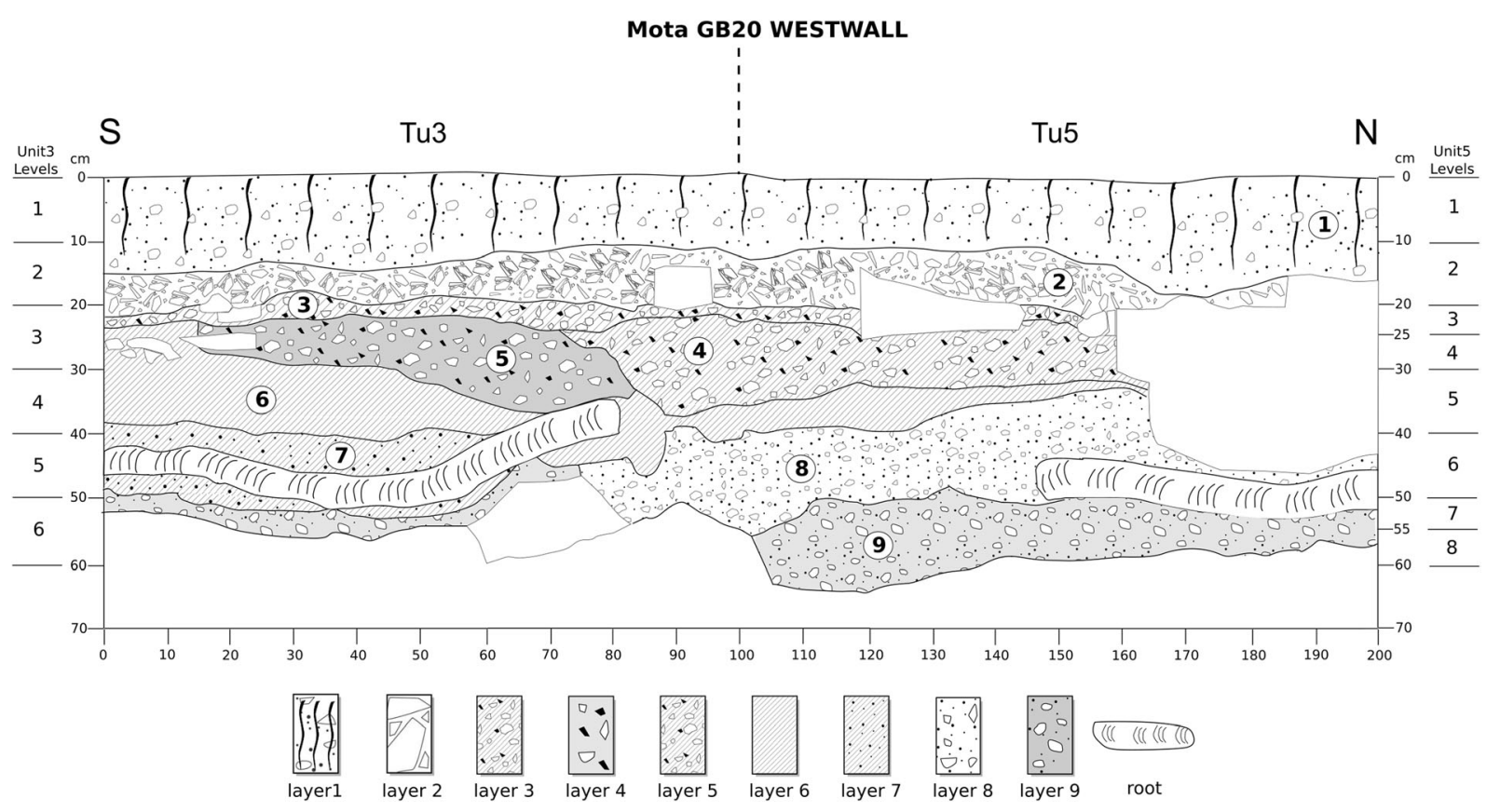

Fig. 6 Mota Cave profile of the western wall of units 3 and 5 


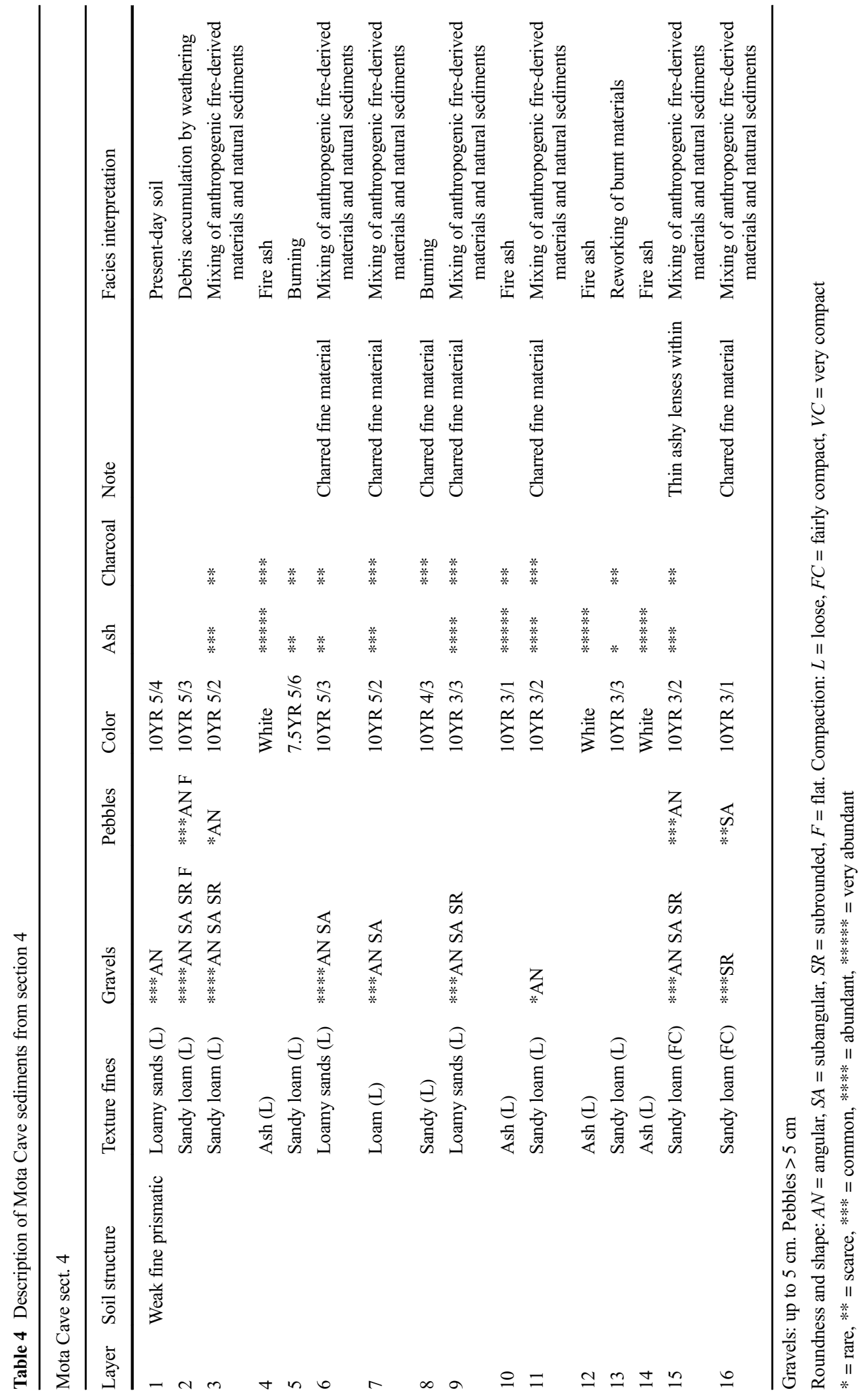




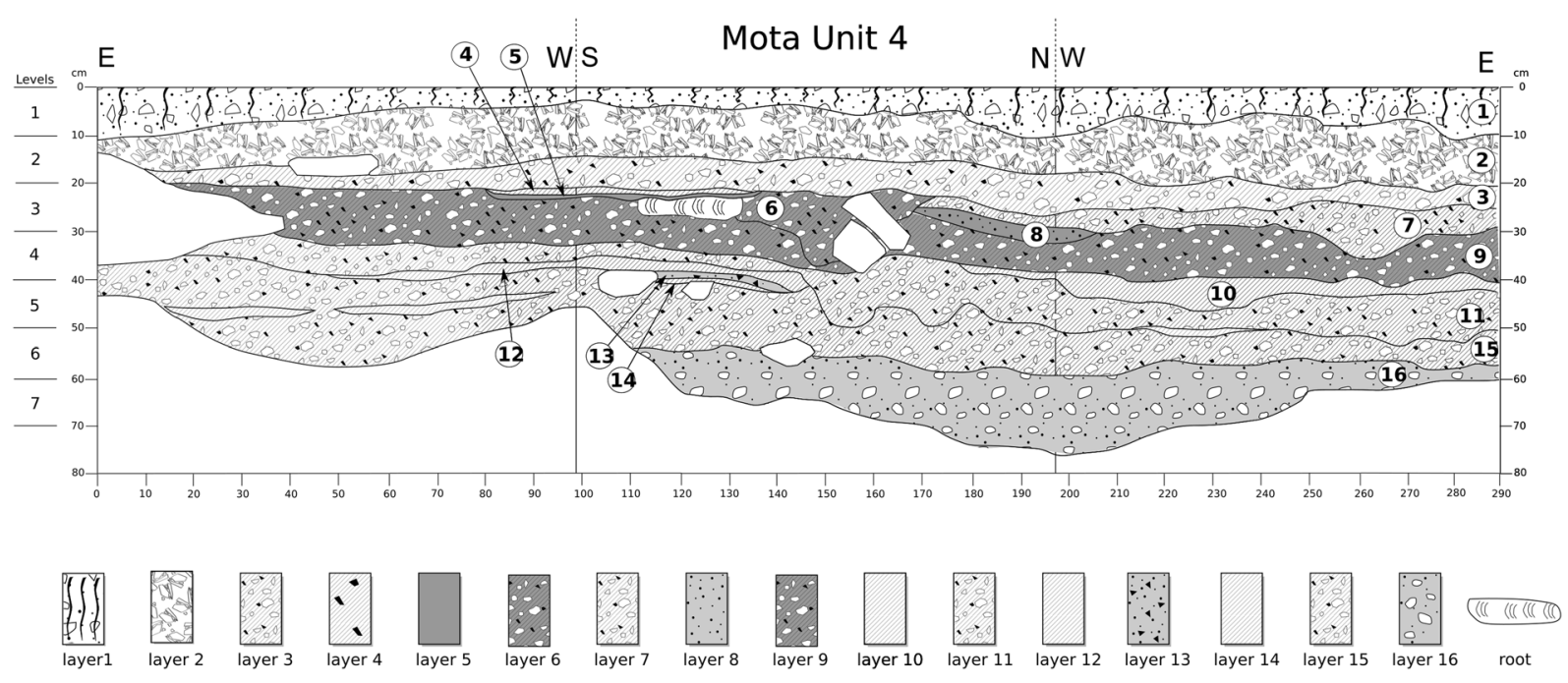

Fig. 7 Mota Cave profile of section 4

A majority of fauna and lithics were recovered near and around the hearth in unit 4 , well dated to between 3340 and $4050 \mathrm{BP}$, indicating that the back portion of the cave was an area of tool making, as well as hide and food processing soon after the internment of the individual in the cairn. A geode was also found near the hearth feature. The presence of four points, including two triangular, an oval, and a tanged point, and geometrics, suggests that animals were likely processed near the hearth. Nearly half of the fauna bones were burned, indicating cooking of the meat on the bone. The presence of end and side scrapers near the hearth also indicates that people either hafted their tools and/or processed hides in this location. The presence of four obsidian and one dark gray chert cores and one hammerstone suggests lithic production near the hearth, though most of the debitage seems to have been removed perhaps to the front of the cave where a large amount of lithic debitage is scattered throughout the burial cairn. We should note that we have not yet conducted refitting studies to determine if debitage and the cores are from the same pieces of raw materials.

Bayira (By-ra), Diet, and Population Dynamics Beginning around $4500 \mathrm{cal}$ BP, people began to use the Mota Cave to bury their dead. Excavations revealed a basalt stone cairn burial with an adult male skeleton from which the first ancient human genome
Fig. 8 Principal components analysis of element values for the obsidian artifacts, showing three main chemical source groups and several outliers likely from other sources

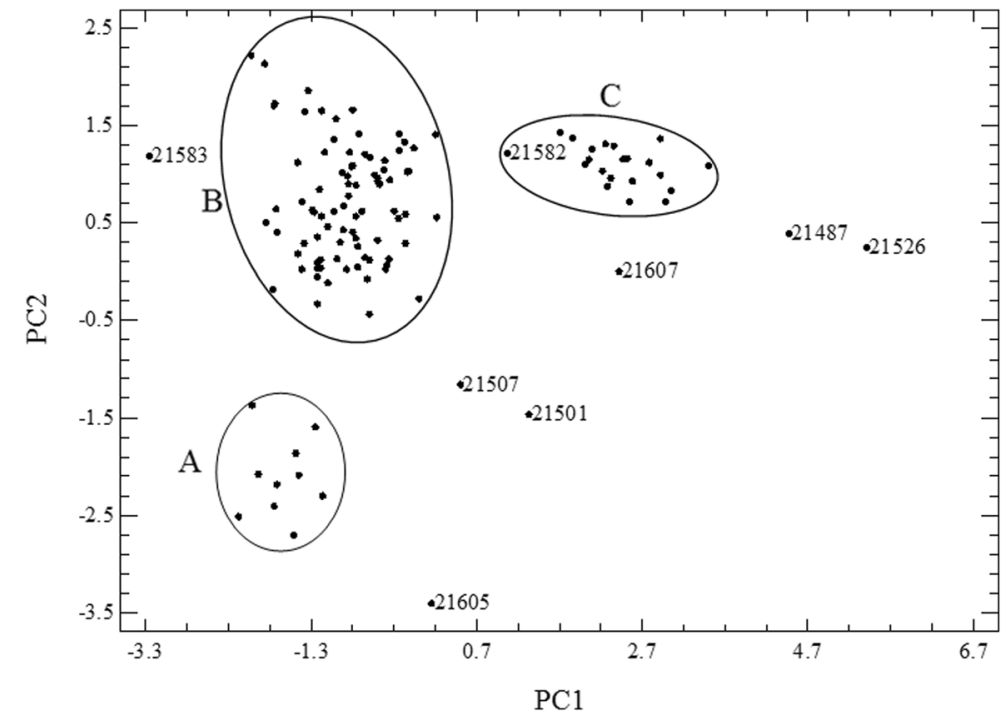




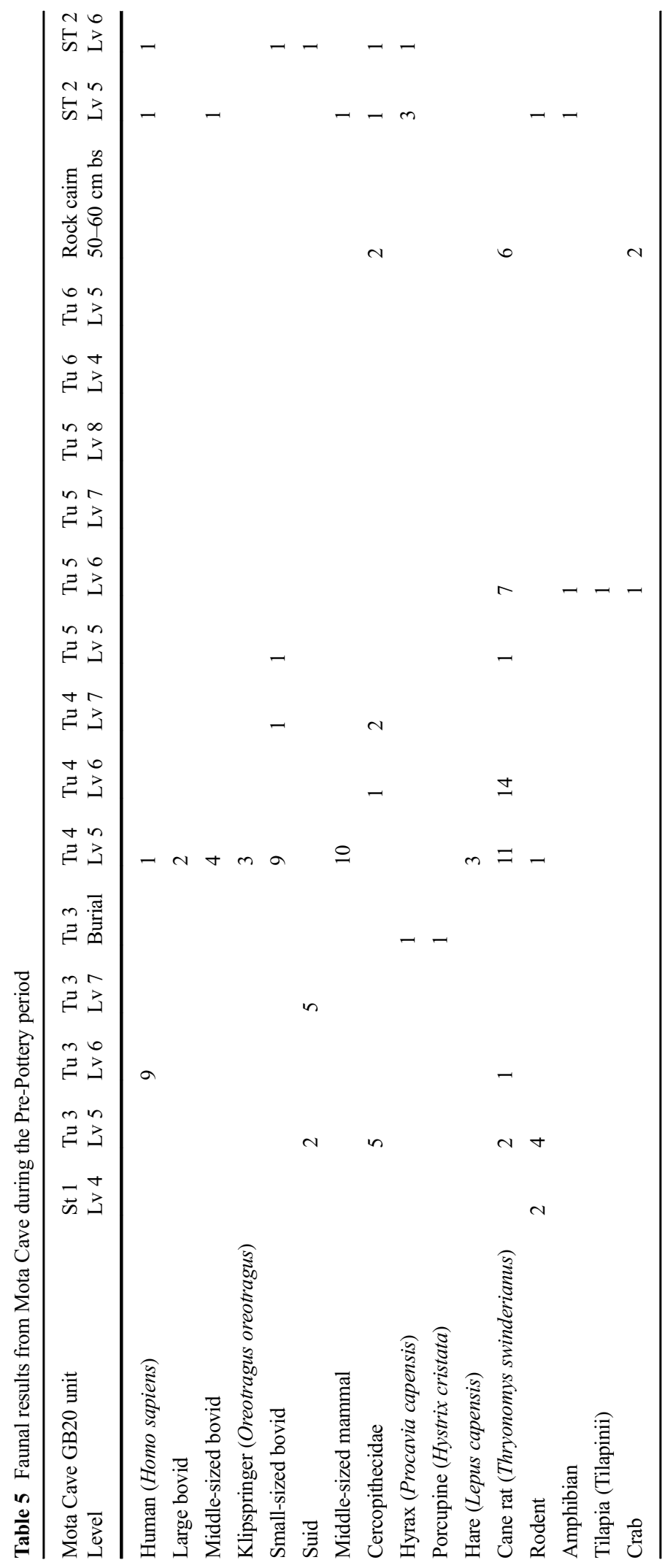




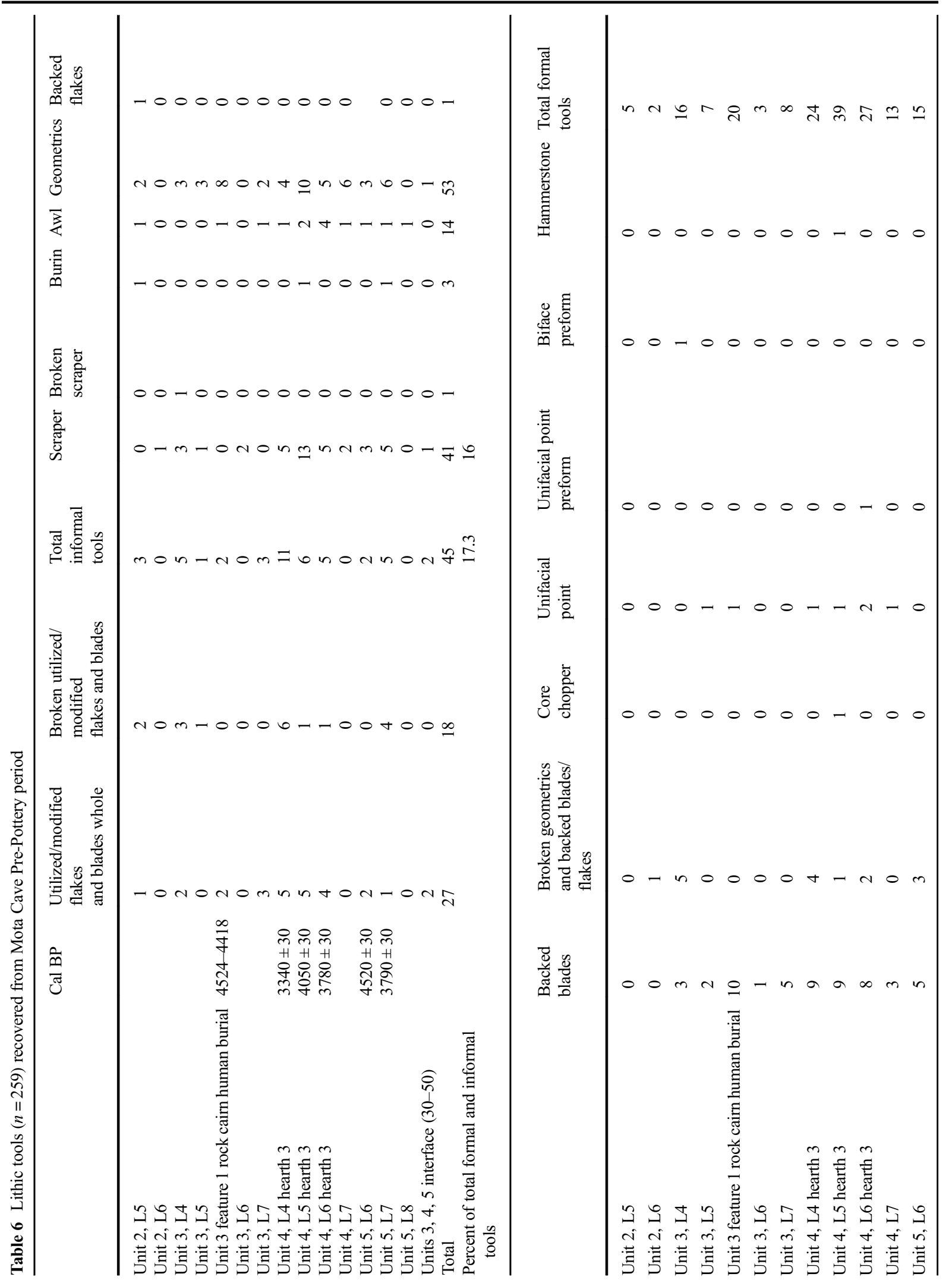




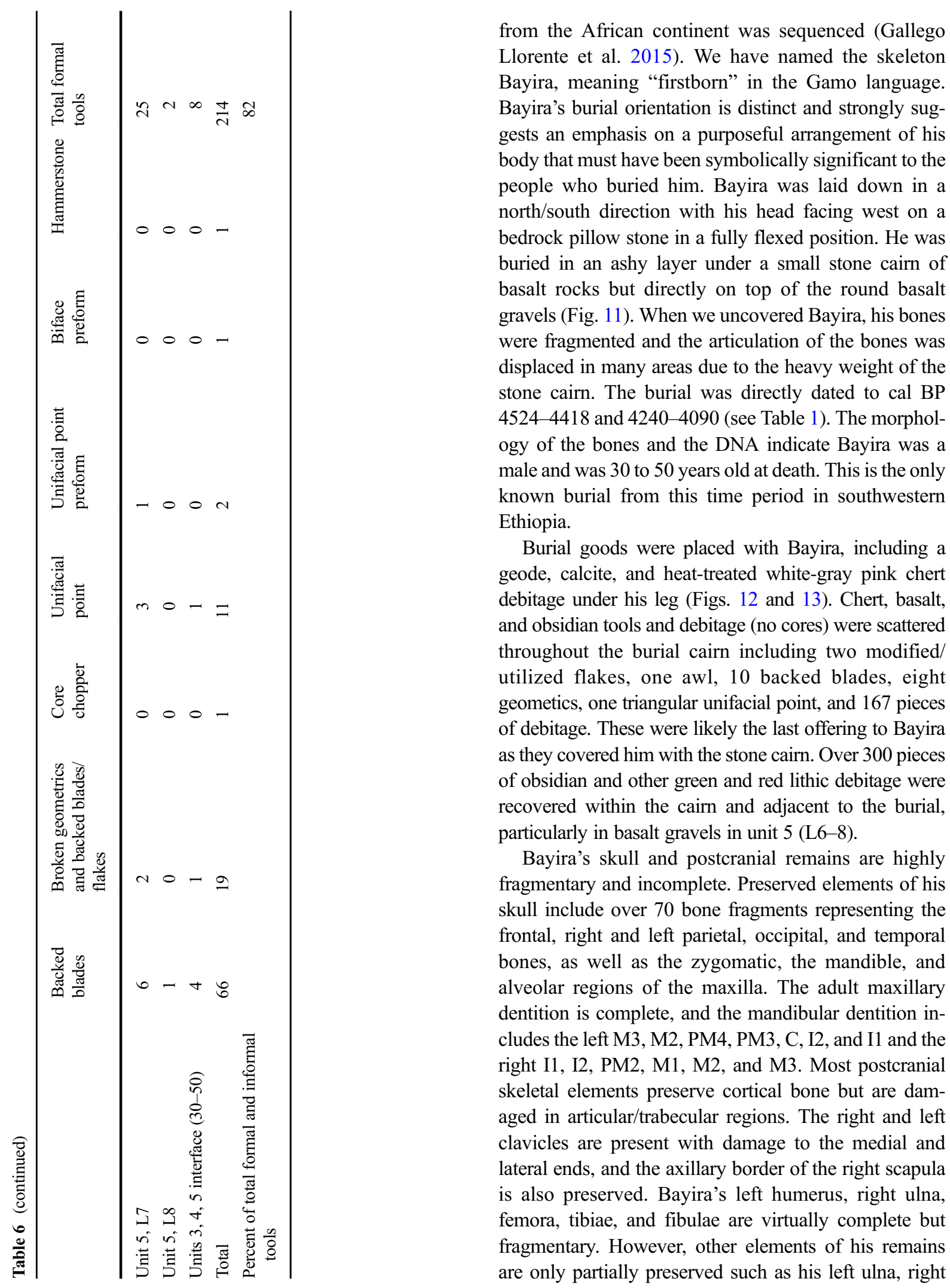



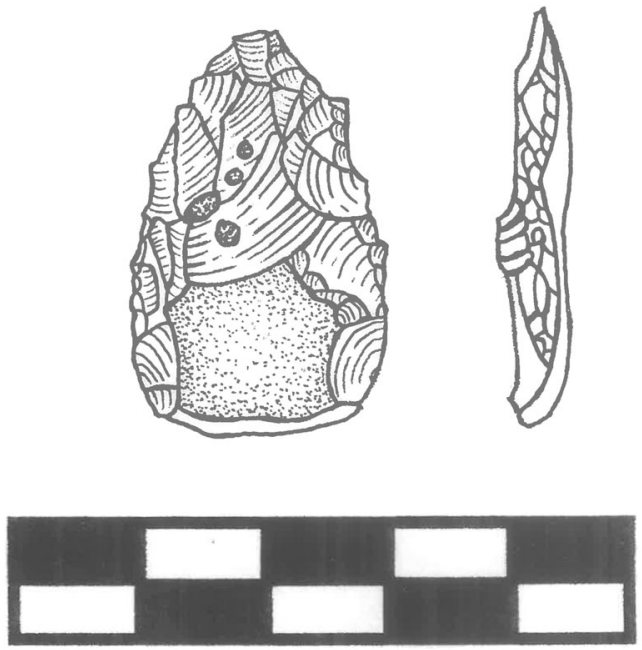

0

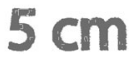

Fig. 9 A unifacial obsidian point found in Mota

and left radii, and innominate bones, and the other regions of his skeleton, including the vertebrae as well as manual and pedal elements, are either absent or highly fragmented.

In agreement with Bayira's aDNA analysis (Gallego Llorente et al. 2015), the osteological analysis confirms that the individual was a male. His pelvis features a relatively narrow sciatic notch and a shallow and broad pre-auricular sulcus. The fragmentary and relatively gracile subpubic ramus features minor subpubic concavity but no ventral arc. However, Bayira's pubic symphysis was not preserved. The sacrum had a narrow $\mathrm{S} 1$ body relative to the breadth of the alae. All the observable features of the pelvis are most consistent with male morphology. Bayira's mandible is well-preserved and he exhibited a prominent mental eminence and trigone, typical of

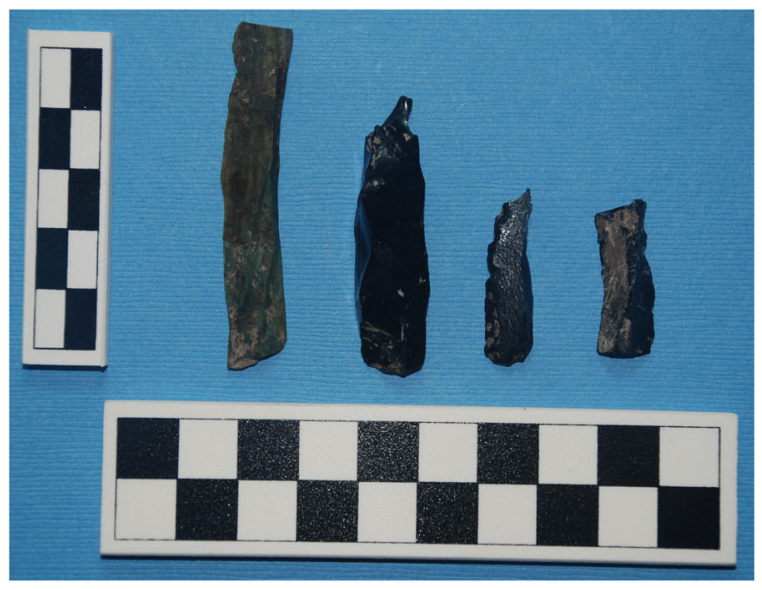

Fig. 10 Blades from Mota Cave category 4 (Buikstra and Ubelaker 1994) and marked gonial flare, which are more consistent with the male sex. His age estimation is possible based on several characteristics. All of his visible epiphyses were fused, including the vertebral annular epiphyses. The ramal epiphysis of the ischium is fused but with a visible line. Bayira's lower third molars were fully erupted, in occlusion, with moderate tooth wear. The left auricular surface of the os coxa (hip bone) has no remaining transverse organization and is characterized by coarse granularity, with some microporosity and moderate retroauricular activity. All of these features indicate that Bayira was a mid-aged adult who died between the ages of 30 and 50 .

Overall, Bayira's skeletal morphology and genetic signature indicates that he was small bodied and gracile, and therefore, had a relatively low body mass. These are characteristics of highland adaption which contemporary local population also share, indicating that the latter may have a deep history in the highlands. Bayira has several elements that are preserved well enough to provide direct osteometric data. The length of the right femur is approximately $418 \mathrm{~mm}( \pm$ $5 \mathrm{~mm}$ ), and the maximum femoral head diameter $(41.77 \mathrm{~mm})$ could be measured directly. The length of the right tibia is estimated at $366 \mathrm{~mm}( \pm 5 \mathrm{~mm})$. No regression equations for the estimation of stature and body mass are available that are specific to populations of the Horn of Africa. Using Feldesman and Fountain's (1996) generic equation for populations of African descent and Raxter's et al. (2008) equation for Egyptian males, Bayira's stature was estimated as $154.8 \mathrm{~cm}$ or $158.2 \mathrm{~cm}$, respectively. In addition, the Bayira's body mass was estimated as $55.16 \mathrm{~kg}$., based on his femoral head diameter (Ruff et al. 1997). The aDNA of Bayira also offers insights into prehistoric adaptation to life in the Ethiopian highlands (Gallego Llorente et al. 2015). His genotype possessed SNP variants in the LIPE and UBAP2 genes, which are thought to be involved in adaptation to hypoxic environments at high altitudes (Udpa et al. 2014).

Stable isotope data obtained from collagen sampled from the petrous bone $\left(\delta^{13} \mathrm{C}=-14.5 \%\right.$; $\delta^{15} \mathrm{~N}=-$ $8.7 \%$ ) suggests that Bayira relied on indigenous foods, particularly $\mathrm{C}_{4}$ pathway foods which may include wild sorghum, finger millet, and/or teff. These African crops, especially their wild spp., have yet to be documented in southern Ethiopia at this early date, and Bayira predates both the origins of agriculture and pastoralism in this area. More rigorous interpretation of these results will 
Table 7 Lithic cores and debitage $(n=1058)$ recovered from Mota Cave Pre-Pottery period

\begin{tabular}{|c|c|c|c|c|c|c|c|c|c|c|c|}
\hline & Cal BP & Cores & $\begin{array}{l}\text { Bipolar } \\
\text { core }\end{array}$ & $\begin{array}{l}\text { Bipolar } \\
\text { core } \\
\text { fragment }\end{array}$ & $\begin{array}{l}\text { Broken } \\
\text { core } \\
\text { fragment }\end{array}$ & Flakes & Blades & $\begin{array}{l}\text { Angular } \\
\text { waste }\end{array}$ & Resharpening & Broken & $\begin{array}{l}\text { Total } \\
\text { debitage }\end{array}$ \\
\hline $\begin{array}{l}\text { Unit } 2 \text {, level } 5 \\
\quad(40-50)\end{array}$ & & 0 & 0 & 0 & 0 & 2 & 0 & 0 & 0 & 1 & 3 \\
\hline $\begin{array}{l}\text { Unit 2, level } 6 \\
\qquad(50-70,20 \mathrm{~cm})\end{array}$ & & 0 & 0 & 0 & 0 & 43 & 3 & 1 & 0 & 45 & 92 \\
\hline $\begin{array}{l}\text { Unit 3, level } 4 \\
\quad(23-30)\end{array}$ & & 1 & 0 & 0 & 0 & 11 & 2 & 2 & 2 & 47 & 64 \\
\hline $\begin{array}{l}\text { Unit 3, level } 5 \\
\quad(30-40)\end{array}$ & & 0 & 1 & 0 & 0 & 27 & 7 & 1 & 1 & 21 & 57 \\
\hline $\begin{array}{l}\text { Unit } 3 \text { feature } 1 \\
\text { rock cairn } \\
\text { human burial }\end{array}$ & $4524-4418$ & 0 & 0 & 0 & 0 & 62 & 5 & 8 & 11 & 81 & 167 \\
\hline $\begin{array}{l}\text { Unit 3, level } 6 \\
\quad(40-50)\end{array}$ & & 1 & 0 & 0 & 0 & 5 & 1 & 1 & 12 & 11 & 30 \\
\hline $\begin{array}{l}\text { Unit 3, level } 7 \\
\quad(50-52)\end{array}$ & & 2 & 0 & 0 & 0 & 11 & 1 & 1 & 1 & 9 & 23 \\
\hline $\begin{array}{l}\text { Unit } 4 \text {, level } 4 \\
\qquad(31-40) \text { hearth }\end{array}$ & $3340 \pm 30$ & 1 & 0 & 0 & 1 & 63 & 13 & 2 & 15 & 35 & 128 \\
\hline $\begin{array}{l}\text { Unit } 4 \text {, level } 5 \\
\quad(40-50) \text { hearth }\end{array}$ & $4050 \pm 30$ & 1 & 2 & 0 & 0 & 10 & 13 & 5 & 8 & 36 & 72 \\
\hline $\begin{array}{l}\text { Unit 4, level } 6 \\
\qquad(50-60) \text { hearth }\end{array}$ & $3780 \pm 30$ & 0 & 0 & 0 & 0 & 62 & 6 & 5 & 2 & 7 & 82 \\
\hline $\begin{array}{l}\text { Unit 4, level } 7 \\
\quad(60-72)\end{array}$ & & 0 & 0 & 0 & 0 & 2 & 0 & 1 & 0 & 6 & 9 \\
\hline $\begin{array}{l}\text { Unit 5, level } 6 \\
\quad(38-50)\end{array}$ & $4520 \pm 30$ & 0 & 0 & 0 & 0 & 30 & 0 & 1 & 0 & 41 & 72 \\
\hline $\begin{array}{l}\text { Unit 5, level } 7 \\
\quad(50-55)\end{array}$ & $3790 \pm 30$ & 1 & 0 & 0 & 0 & 43 & 9 & 7 & 14 & 152 & 225 \\
\hline $\begin{array}{l}\text { Unit } 5 \text {, level } 8 \text { ( } 55 \\
\text { to bedrock) }\end{array}$ & & 0 & 0 & 0 & 0 & 5 & 0 & 0 & 0 & 8 & 13 \\
\hline $\begin{array}{l}\text { Units } 3,4,5 \\
\quad \text { interface (30-50) }\end{array}$ & & 0 & 0 & 0 & 0 & 5 & 0 & 2 & 1 & 2 & 10 \\
\hline Total & & 7 & 3 & 0 & 1 & 381 & 60 & 37 & 67 & 502 & 1,047 \\
\hline
\end{tabular}

require a detailed analysis of the isotopic signature of local food webs. Bayira's genome also indicates that he possessed none of the alleles known to be associated with lactase persistence, suggesting that he was not engaged in pastoralism 4,500 years ago.

Besides being the first ancient genome sequenced from Africa, Bayira's skeleton and the archaeological record associated with him provide an opportunity to examine ancient regional and interregional population dynamics. This individual predates a Eurasian gene flow into parts of northeastern Africa that seems to have occurred after 3,000 years BP (Gallego Llorente et al. 2015). His aDNA data therefore presents relatively nonadmixed African genomic reference for exploring much more recent demographic events in the region.
Hence, with Bayira as a reference point, geneticists have demonstrated a significant level of western Eurasian admixture in genomes in East Africa after 3,000 years BP, similar to Neolithic (LBK) genomes in Europe. The mechanisms by which this happened are unclear but may have been due to gene flow related to specific population interactions in the Southern Red Sea area or elsewhere in northeastern Africa followed by gene flow among African populations across the continent. Archaeological and epigraphic evidence does suggest that beginning about 3,000 years BP interaction between polities in the northern Horn of Africa and the Southern Arabian Peninsula intensified and new forms of sociopolitical and economic organization appeared, perhaps as a consequence of this interaction (Curtis 


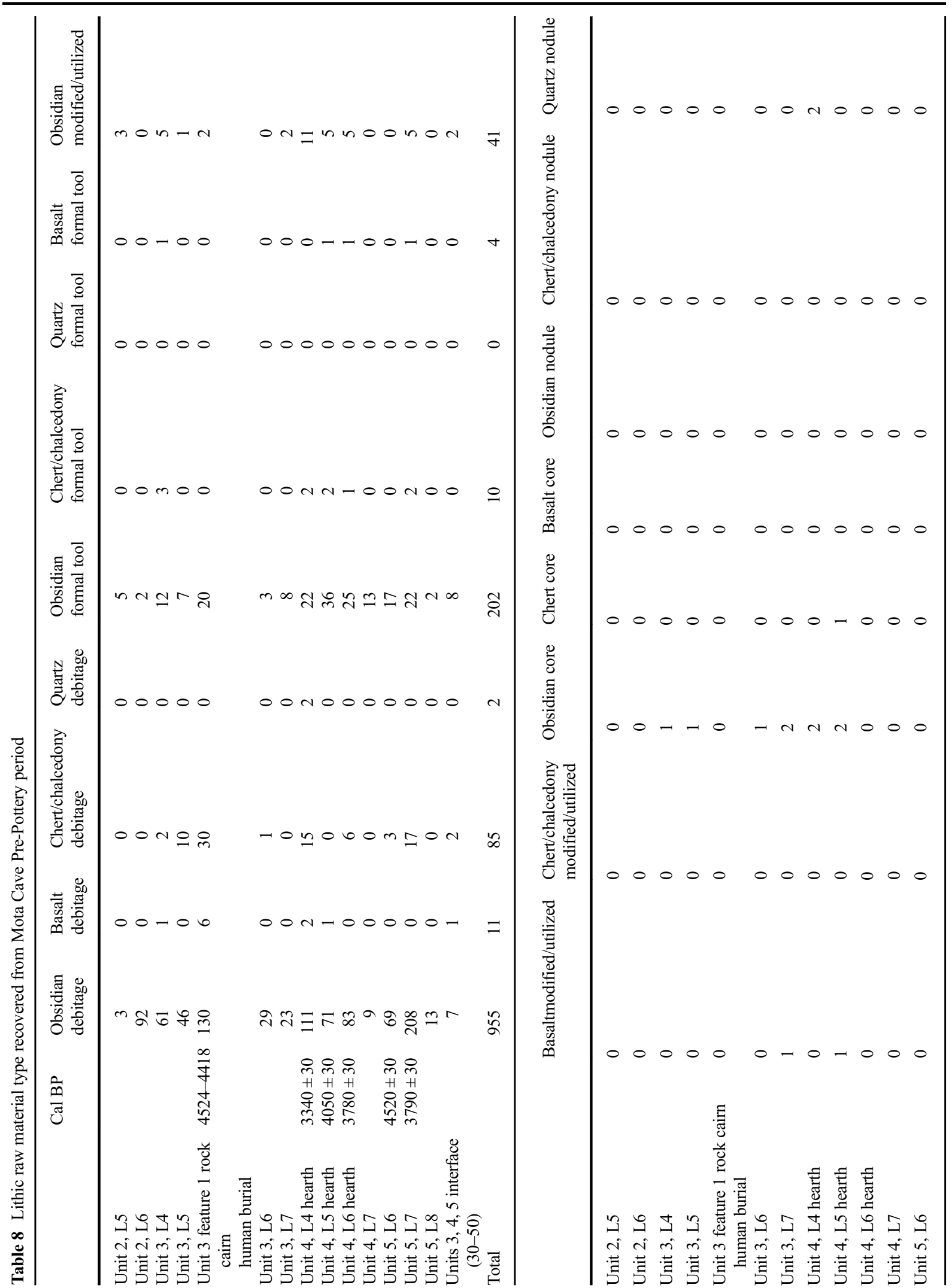




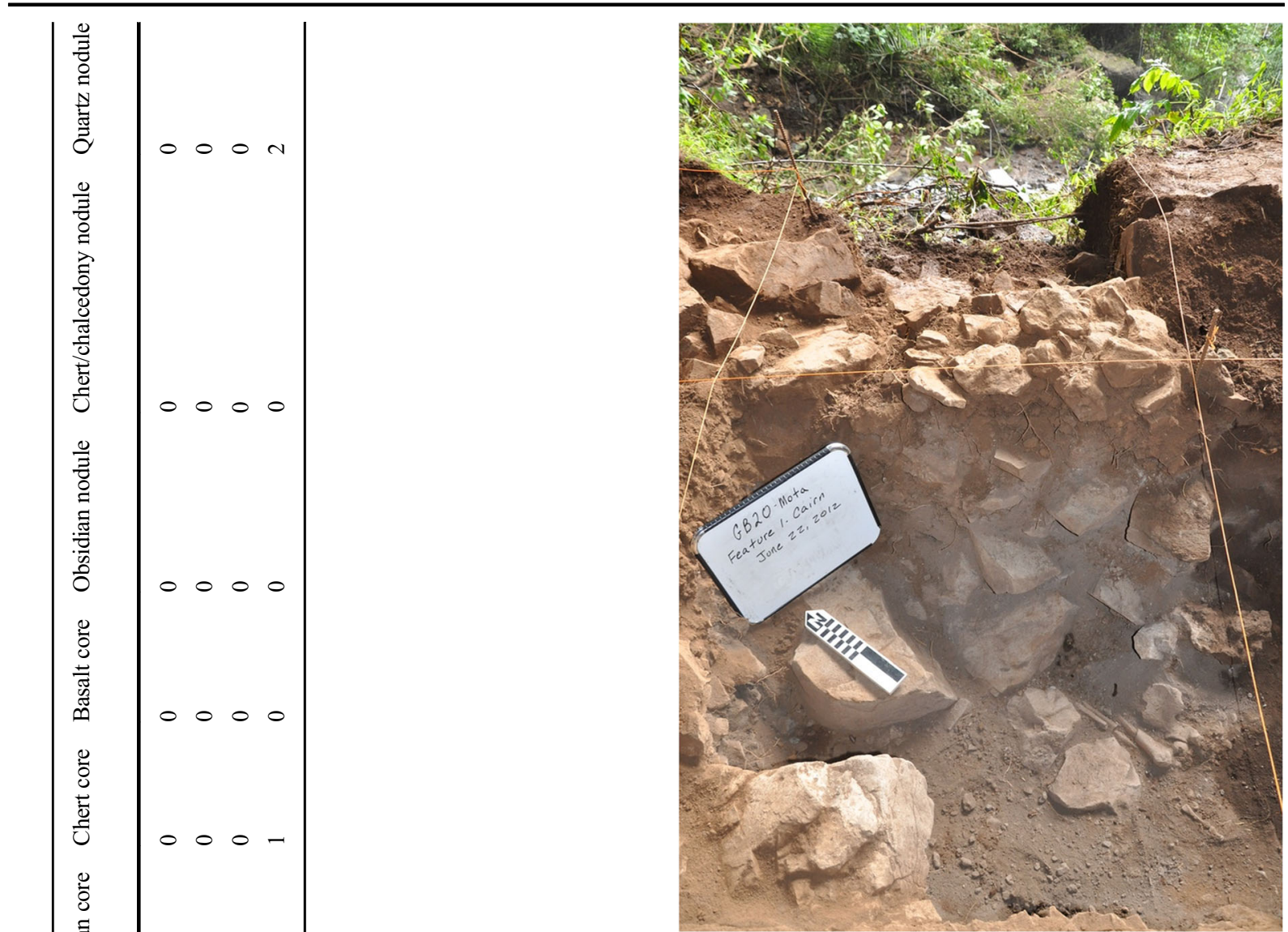

Fig. 11 Rock cairn in Mota Cave

2004, 2008, 2009; Fattovich 2010, 2012; Harrower and D’Andrea 2014; Manzo 2009).

Bayira also helps us begin to piece together the population history of southwestern Ethiopia. Genetically, this individual is closest to the Ari ethnic group (Gallego Llorente et al. 2015), an Omotic-speaking

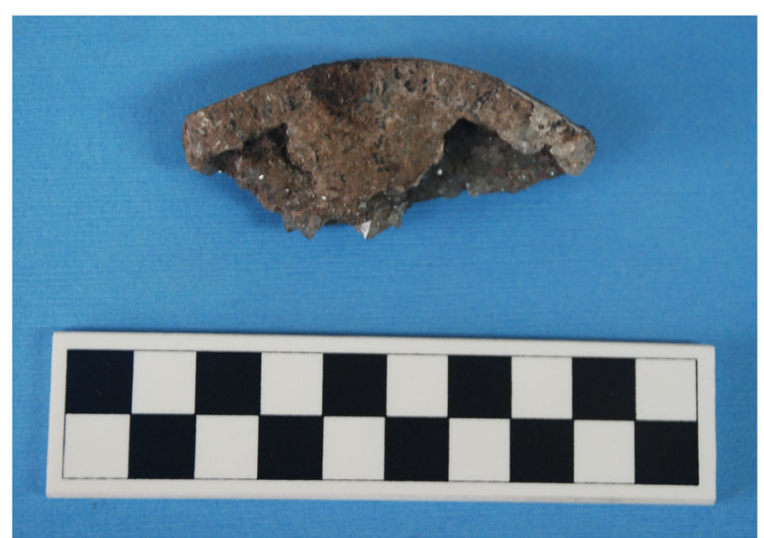

Fig. 12 Geode found in association with the burial Bayira in Mota Cave 


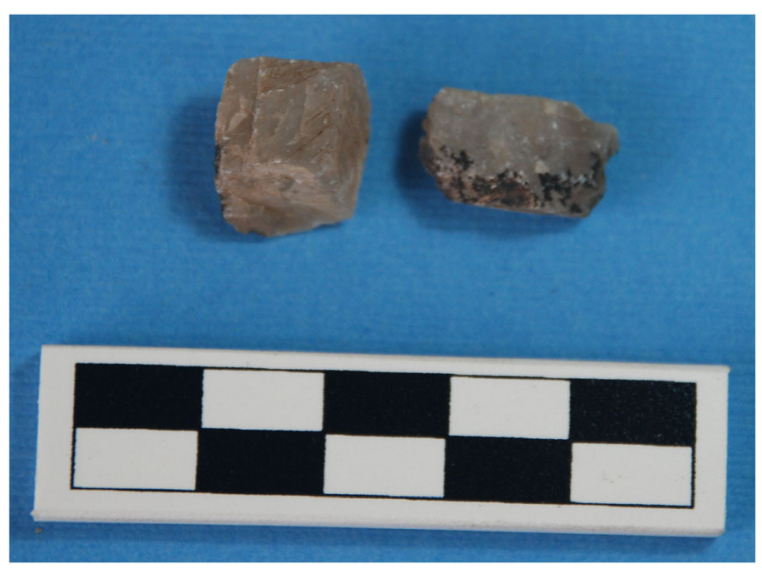

Fig. 13 Calcite found in association with the burial Bayira in Mota Cave

society living in southwestern Ethiopia today. Currently, no living people from the Gamo Highlands where Bayira lived have been genetically sequenced for comparison, so future research will be required to fully understand the genetic relationships between Bayira and the people living in the Gamo Highlands today. The Omotic languages are linguistically the most divergent of the Afroasiatic language phylum, suggesting that Omotic speakers may have lived in southwestern Ethiopia for a long and sustained period of time (Ehret 2000, p. 290). The 4,500-year-old remains of Bayira may lend support to this view.

\section{Early Pottery Period and Middle Occupation ( 2370-1620 Cal BP)}

Two highly fragmented sherds with either a polished or burnished surface were recovered near a hearth feature at Mota and possibly date as early as 3340 BP (unit 4 L4, Table 9). However, the absence of pottery in other contemporaneous units/levels dating to this earlier time suggests that these two sherds may represent a slippage of material from the upper strata. Although the advent of pottery in the archaeological sequence of Mota is unclear, it is certain that potters were using red slip on the exterior and interior surfaces of pottery vessels ca. 2400 BP. Thirty of these sherds have been firmly dated to $2370-1620$ BP. The use of red slip was unique to the long tradition of pottery production in southwestern Ethiopia (Fig. 14). Beginning around 2400 BP, the people at Mota were not only utilizing pottery, they were also cultivating domesticated crops. However, domesticated animals did not appear for nearly another
1,000 years. Instead, they obtained their meat protein by hunting small bovids living in the highland montane zones. The Early Pottery people persisted in producing microlithic tools. Although tools represent only $7 \%$ of the assemblage, there is a higher density of lithics during this period at 0.00112 per $\mathrm{cm}^{3}$. Nearly all the lithic tools are obsidian and there is only one chert scraper (a bit of debitage and no cores). There may have been an increased access to the lowland obsidian sources. This implies that the highland peoples were also in greater contact with the lowland pastoralists from whom they likely obtained domesticated animals.

The recovery of a single barley grain from unit 2 , level 3 may indicate that the consumption of barley began in the Gamo Highlands ca. 2400 BP. Despite extensive flotation of 47 samples (940 liters of sediment), only 10 plant macroremains (excluding wood) were recovered from among 7 samples. The barley grain was submitted for AMS radiocarbon dating to the Scottish Universities Environmental Research Centre (SUERC), University of Glasgow. However, the dating did not succeed due to insufficient carbon after pretreatment. Nevertheless, this level is dated with charcoal to ca. $2400 \mathrm{BP}$, suggesting that barley and cereal farming may have been established in this region sometime during the third millennium BP (see Table 1). In Mota Cave, the evidence for domesticated sheep (Ovis aries)/goat (Capra hircus) appears in the archaeological sequence ca. $1700 \mathrm{cal} \mathrm{BP}$ and that of cattle (Bos taurus) ca. 1620 cal BP. However, hunting, which particularly focused on bush pig, bushbuck, and klipspringer, continued to be an important source for protein, hides, and other materials.

The Early Pottery lithic assemblage comprised of microlithic tool production, and this was characterized by flake ( $89 \%$ ) and blade (11\%) debitage produced from obsidian pyramidal, double platform, single platform, and bipolar cores (Tables 10, 11, and 12). Obsidian broken cores, a few broken tools, and hundreds of broken pieces of debitage are associated with knapping during this period. Broken cores and an abundance of debitage, of which $43 \%$ is cortical, are indicative of inexperienced knappers. Cross-cultural ethnographic studies have shown that novice knappers tend to produce larger amounts of debitage and are more likely to select poorer quality raw materials compared to experienced knappers (Arthur 2018, p. 146-150). Alternatively, this large debitage assemblage may represent the production of tool blanks such that tool refinement occurred in another location. 
Afr Archaeol Rev (2019) 36:5-65

25

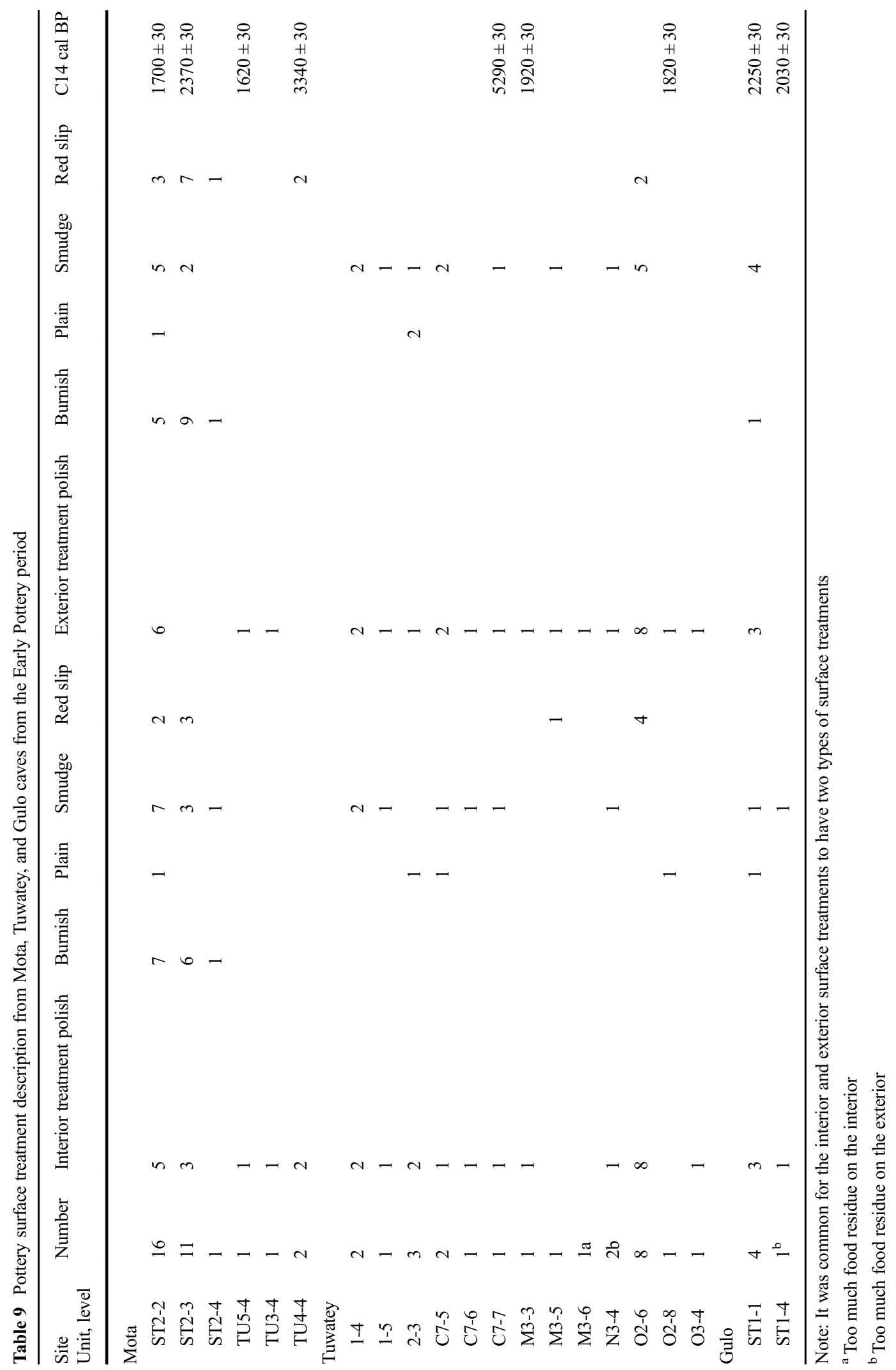

Springer 
We found two circular rock hearth features at the site dating to the Early Pottery period. One was in test unit 2 (L2-4) in the back of the cave in association with a triangular unifacial obsidian point, pottery, burned bone, and shell dating to 1700-2370 BP. The hearth had large amounts of charcoal and ash and was constructed with small stones. There were a few tools in the hearth area, including an end and a side scraper, scraper core, geometric tools, and utilized and modified flakes. These tools are indicative of cutting and hide working and/or hafting activities. Only end and side scrapers with single working edges were present during this period, suggesting that people likely hafted their tools in closed mastic hafts compared to the open hafts of the Pre-Pottery period. The presence of numerous broken cores and abundant debitage at the bottom of the hearth feature may suggest that people were discarding their waste material in this hearth or using it as an insulator. There was an extensive amount of faunal remains associated with this hearth including one sheep/goat element; small, medium, and large bovids; bushbuck (Tragelaphus scriptus); hyrax (Procavia capensis); suid; middle-sized mammal; cane rat; and rodents (Table 13). The pottery associated with the hearth consisted of 26 body sherds and one unidentifiable small rim sherd with a variety of surface treatments, including burnishing, plain, smudge, and red slip on the interior and exterior. Use-alteration analysis indicates that the vessels were used for cooking and other food processing activities as evident in the interior food residue

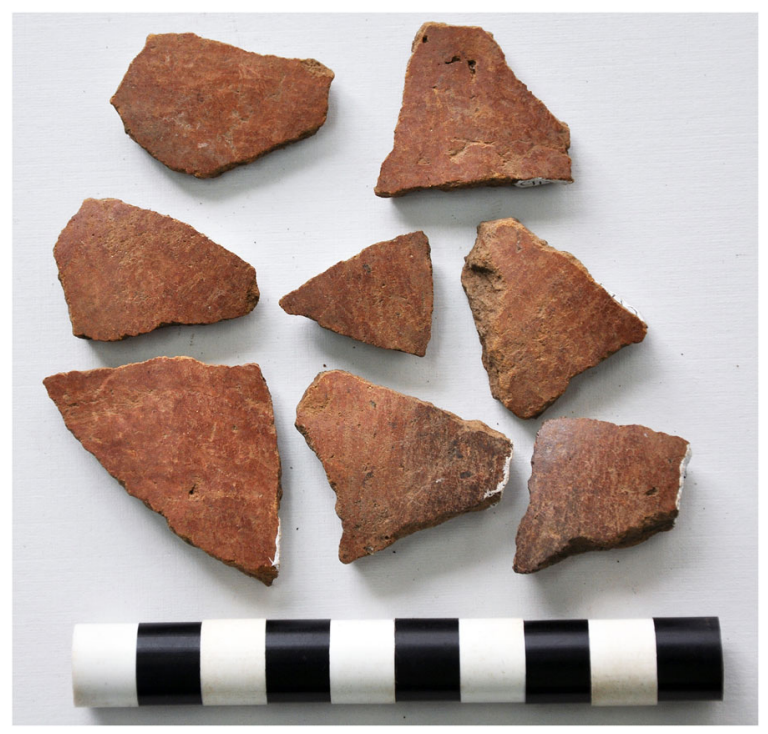

Fig. 14 Mota Cave pottery showing red slip surface treatment $(n=4)$. They were also possibly used for the fermentation of either dairy products or beer production based on interior wear and pitting $(n=6)$ (Table 14) (Arthur 2002, 2003, 2014).

The second hearth, found in test unit 5 , extends into unit 1 and dates to ca. 1600 BP. Stones also were arranged to encircle the hearth which was about $50 \mathrm{~cm}$ in diameter and containing ashy soil and a large amount of charcoal. Obsidian tools are found in this hearth but not in abundant numbers. These tools included a few modified/utilized flakes and blades, scrapers (end and side scrapers), a burin, an awl, and some geometrics (crescent, backed blade, trapezoid). All of these indicate cutting and scraping/scraper haft replacement activities near the hearth. A bipolar core and two pyramidal cores attest to tool making. The faunal elements found in this hearth include one cattle (Bos taurus) element, smallsized bovid, baboon (Papio anubis), aardvark (Orycteropus afer), rodent, and amphibian elements. The pottery included only one body sherd that has a polished interior and exterior.

The Historic Period and Last Occupation (330-300 Cal $B P)$

By 330 BP, Mota Cave was occupied again. The new occupants also engaged in hunting and gathering and consumed tubers and more domesticates. There were far more ceramics in the Historic period than in the Early Pottery period. In contrast, there were fewer stone tools, though the obsidian and chert microlithic technology continued (Tables 15, 16, and 17). While in the PrePottery period, pXRF analysis indicates the exploitation of three main obsidian sources, only two of these sources continued to be utilized during the Historic period analysis based on the analysis of 39 pieces from unit 4 (Fig. 8). Furthermore, quartz is added as a knapping resource at this time. Only two areas of the cave were the focus of human activity during this time - the very front and the back of the cave.

Boreda elders stated that in the past they and their ancestors prepared and brought barley beer and animal's blood to the entrance of the cave for offerings to ancestral and nature spirits. This would explain the presence of serving vessels, such as bowls and plates in units at the front of the cave-TU3, 6, and 7. Two of the bowls are large with rim diameters of 30 and $38 \mathrm{~cm}$. They may have served as communal eating bowls and/or storage vessels. One bowl was much smaller with only a $14-\mathrm{cm}$ 


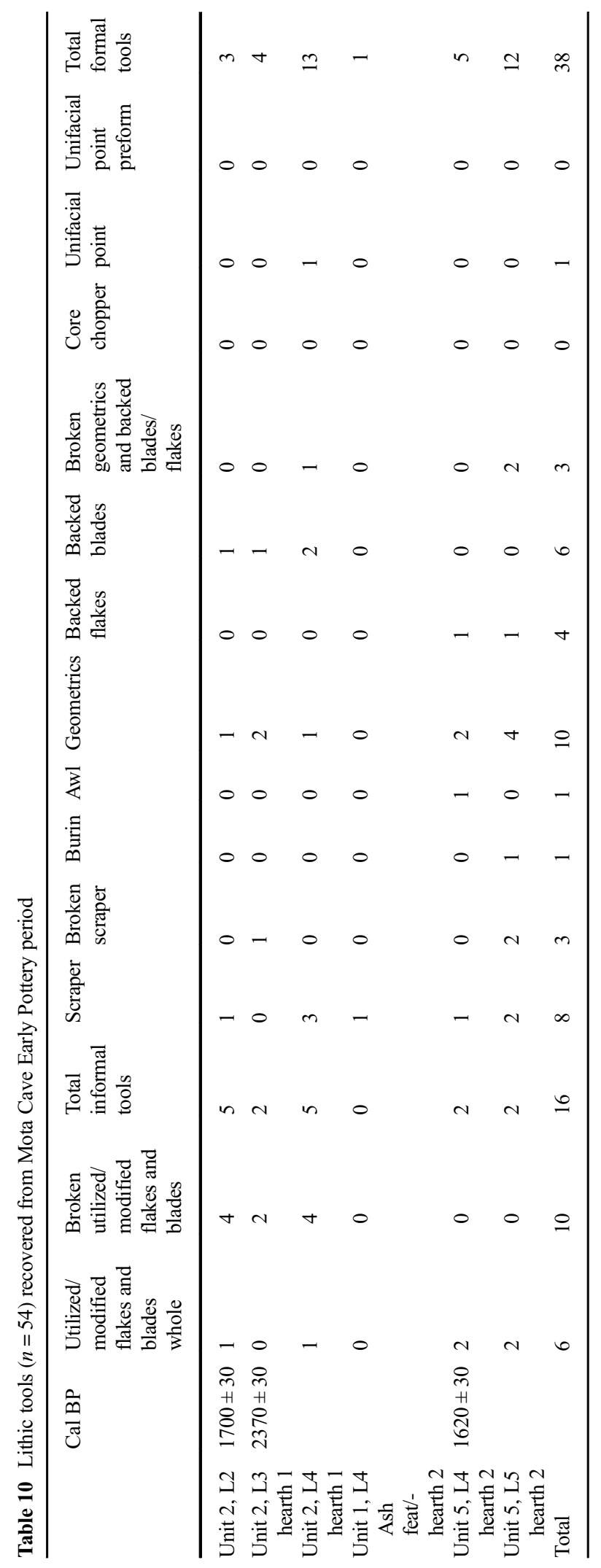


Table 11 Lithic cores and debitage $(n=643)$ recovered from Mota Cave Early Pottery period

\begin{tabular}{|c|c|c|c|c|c|c|c|c|c|c|c|}
\hline & Cal BP & Cores & $\begin{array}{l}\text { Bipolar } \\
\text { core }\end{array}$ & $\begin{array}{l}\text { Bipolar } \\
\text { core } \\
\text { fragment }\end{array}$ & $\begin{array}{l}\text { Broken } \\
\text { core } \\
\text { fragment }\end{array}$ & Flakes & Blades & $\begin{array}{l}\text { Angular } \\
\text { waste }\end{array}$ & Resharpening & Broken & $\begin{array}{l}\text { Total } \\
\text { debitage }\end{array}$ \\
\hline Unit 2, L2 & $1700 \pm 30$ & 0 & 0 & 0 & 0 & 9 & 0 & 20 & 0 & 10 & 39 \\
\hline Unit 2, L3 hearth & $2370 \pm 30$ & 0 & 0 & 0 & 1 & 3 & 0 & 9 & 0 & 65 & 77 \\
\hline $\begin{array}{l}\text { Unit 2, level } 4 \\
\quad(30-40) \text { hearth }\end{array}$ & & 1 & 0 & 0 & 2 & 36 & 10 & 38 & 1 & 112 & 197 \\
\hline $\begin{array}{l}\text { Unit } 1 \text {, level } 4 \\
\text { (20-28-ash } \\
\text { feature) }\end{array}$ & & 0 & 0 & 0 & 0 & 0 & 0 & 0 & 0 & 0 & 0 \\
\hline $\begin{array}{l}\text { Unit 5, level } 4 \\
\quad(25-30) \text { hearth }\end{array}$ & $1620 \pm 30$ & 0 & 2 & 0 & 0 & 31 & 2 & 1 & 8 & 16 & 58 \\
\hline $\begin{array}{l}\text { Unit 5, level } 5 \\
\quad(30-38) \text { hearth }\end{array}$ & & 2 & 0 & 1 & 1 & 81 & 9 & 1 & 15 & 136 & 242 \\
\hline $\begin{array}{l}\text { Unit } 5, \text { L4 feature } \\
\quad 2\end{array}$ & & 0 & 0 & 0 & 0 & 9 & 0 & 0 & 3 & 8 & 20 \\
\hline Total & & 3 & 2 & 1 & 4 & 169 & 21 & 69 & 27 & 347 & 633 \\
\hline
\end{tabular}

diameter. One large plate with a 50-cm diameter could have served as a bache, a form that is used in ethnographic context to cook injera, a sourdough-risen flatbread made out of teff flour (Tables 18 and 19; Arthur 2006). The pottery, based on wear and pitting found on the interior of the vessels, also shows that foods containing dairy products and/or beer were being utilized. In addition, the exteriors of the vessels have a severe wear pattern suggesting that the pottery was intensely used for serving and/or storage of foods and may have been moved around (Table 14). Bovid spp., sheep, and hare and carbonized parenchyma (tuber fragments) were also identified in this part of the cave along with scrapers, burins, geometrics, and utilized and modified flakes (Tables 15 and 20). This occupation level indicates that people were engaging less in lithic technology (394 lithics, density of 0.0002 per $\mathrm{cm}^{3}$ ) compared to earlier periods.

Elders also stated that they used the cave in times of war to hide. While annual ritual hunting is acknowledged prior to the late twentieth century, mostly large bovids were favored in those hunting events. Therefore, the evidence of smaller animals such as small- and mediumsized wild bovids, hare, and cane rats in the cave may indicate need-based consumption while the people were in hiding and in distress. Carbonized parenchyma (tuber) fragments (unit 3, L2) also indicate the consumption of tubers during this time (Table 21). Unit 4 contained the densest amount of artifacts for this time period. These included burned wood, burned rock, human teeth, ceramics, and stone tools. An informal hearth feature, comprising of an ashy deposit with burned rocks and gravels but without a formal circle of stones, was found in this portion of the cave. Charcoal recovered from this context dates the hearth to $300 \mathrm{BP}$. One large jar rim with a 16-cm diameter rim was also found in this location. This could have served as a cooking and/or storage vessel. On the basis of interior food residue $(n=4)$, wear $(n=6)$, exterior carbon deposition $(n=2)$, and pitting $(n=2)$, the usealteration of the body sherds indicates cooking and/or storage as the predominant functions of the vessels (Table 14). In addition, microlithic backed crescents and other geometrics were found near this hearth feature showing that the occupants also engaged with cuttingrelated activities (Fig. 15). Scrapers, awls, and a burin were recovered in this area, indicating hide processing and/or replacing of scrapers in hafts. However, most of the scrapers had multiple-use edges suggesting that people were likely using an open haft with rope or string rather than mastic to secure their scrapers, as was the case during the Pre-Pottery occupation. Half of the scrapers in this area are spurred suggesting the presence of novice tool users (Arthur 2018, p. 166-169).

\section{Tuwatey Cave (Site GB15)}

Tuwatey Cave was occupied between ca. 5520 and 300 BP (Table 1). However, the archaeological 


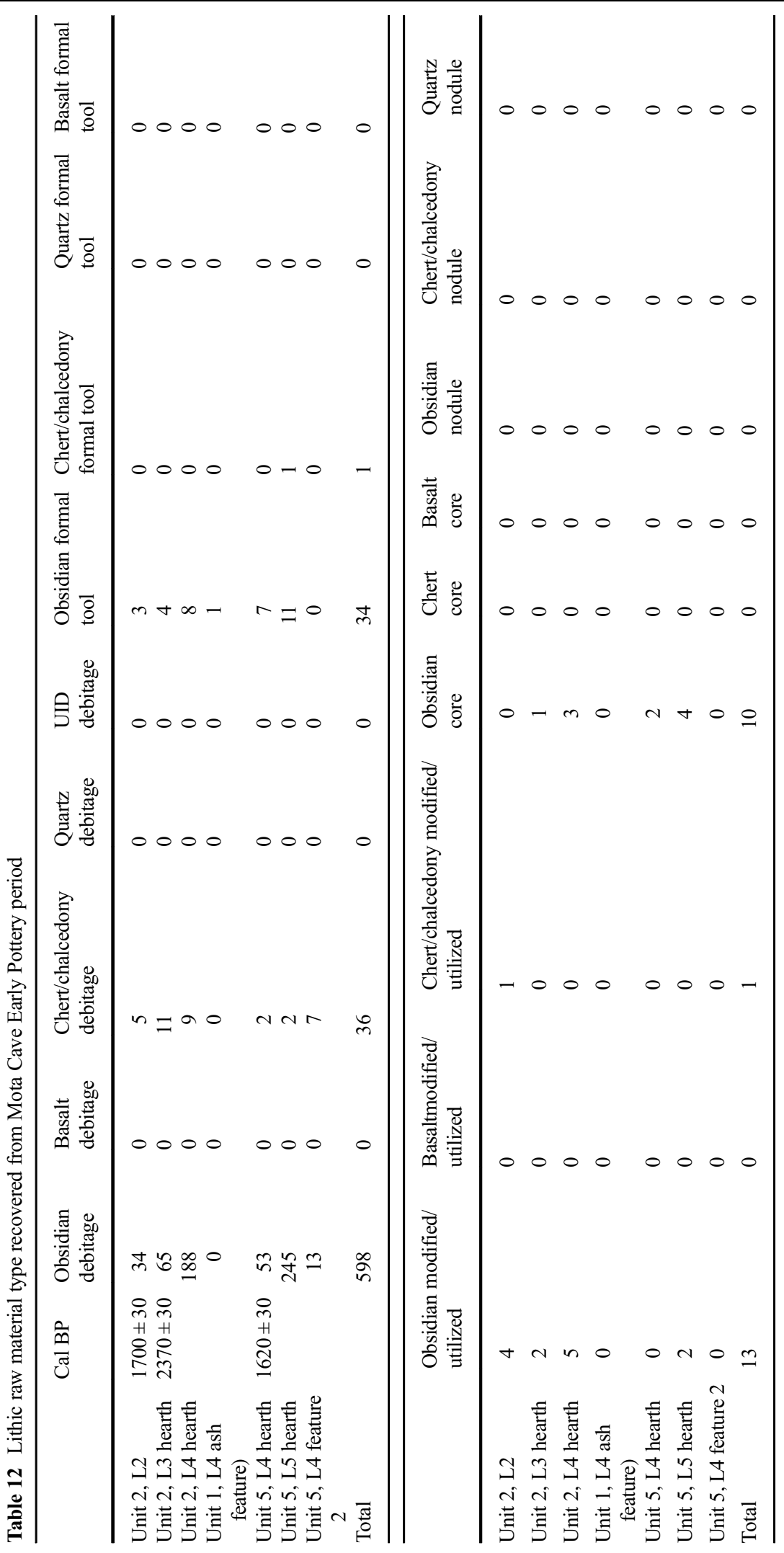


Table 13 Faunal results from Mota Cave during the Early Pottery period

\begin{tabular}{|c|c|c|c|c|c|c|c|}
\hline $\begin{array}{l}\text { Mota Cave GB20 unit } \\
\text { Level }\end{array}$ & $\begin{array}{l}\text { Tu } 3 \\
\text { Lv } 4\end{array}$ & $\begin{array}{l}\mathrm{Tu} 4 \\
\mathrm{Lv} 4\end{array}$ & $\begin{array}{l}\text { Tu } 5 \\
\text { Lv } 4\end{array}$ & $\begin{array}{l}\text { Tu } 7 \\
\text { Lv } 2\end{array}$ & $\begin{array}{l}\text { ST } 2 \\
\text { Lv } 2\end{array}$ & $\begin{array}{l}\text { ST } 2 \\
\text { Lv } 3\end{array}$ & $\begin{array}{l}\text { ST } 2 \\
\text { Lv } 4\end{array}$ \\
\hline Large bovid & 1 & & & & & & 1 \\
\hline Cattle (Bos taurus) & & & 1 & & & & \\
\hline Sheep (Ovis aries)/goat (Capra hircus) & & & & & 1 & & \\
\hline Bushbuck (Tragelaphus scriptus) & & 2 & & & & 2 & \\
\hline Middle-sized bovid & 2 & 1 & & & & 4 & \\
\hline Klipspringer (Oreotragus oreotragus) & & 1 & & & & 2 & \\
\hline Small-sized bovid & & 8 & 1 & & 5 & 1 & 4 \\
\hline Suid & & 1 & & & & 4 & \\
\hline Middle-sized mammal & & 4 & & & & & \\
\hline Baboon (Papio anubis) & & & 1 & & & & \\
\hline \multicolumn{8}{|l|}{ Cercopithecidae } \\
\hline Aardvarks (Orycteropus afer) & & & 1 & & & & \\
\hline Hyrax (Procavia capensis) & & & & & & & 2 \\
\hline Hare (Lepus capensis) & 3 & & & & & & \\
\hline Cane rat (Thryonomys swinderianus) & 2 & & & & & 1 & 5 \\
\hline \multicolumn{8}{|l|}{ Small mammal } \\
\hline Rodent & & 1 & 2 & & 3 & 4 & \\
\hline Bat & 2 & & & & & & \\
\hline Amphibian & & & 2 & & & & \\
\hline Crab & & & & 4 & & & \\
\hline
\end{tabular}

sequence suggests that the activities in Tuwatey were much different than those at Mota. Tuwatey overlooks the Kulano River, a major tributary of the Omo River and is located $2,037 \mathrm{~m}$ above sea level on the eastern escarpment of the Boreda Gamo Highlands. This cave was documented in 2007 with the assistance of Gamo elders. Tuwatey literally means "immature child excited to come out." At Tuwatey, elders made ritual offerings when a new child was born, and in the Historic period, their ancestors hid there during war and insecurity.

We excavated parts of the cave during the 2007, 2011, and 2012 field seasons. The cave possesses a main chamber measuring $15 \mathrm{~m}$ in width and $20 \mathrm{~m}$ in depth (Figs. 16 and 17). Eleven square meters of excavation in 2007 and 2012 has revealed extensive hearth features in several areas of the central chamber including units TU1 (L3-4), TU2 (L4-5), J5 (L6), and M3 (L5-6). The hearth features were not associated with patterned rock outlines as was found at Mota Cave but contained extensive amounts of ash and charcoal. Geochemical analysis of Tuwatey indicates that people were intensively using fire in the cave. There are laminated clays in the upper levels of the cave, followed by an accumulation and diagenesis of bat guano which overlays abundant areas of dense charcoal and ash indicating a heavy use of the site for making fireplaces. These sediments continue to be interspersed with guano and charcoal lenses down to the bedrock (Tables 22 and 23 and Figs. 18 and 19). Analysis of microliminology reveals that there are fires associated with the cultural facies, all indicating that individuals were modifying the cave by (a) burning materials in situ, (b) reworking and/or trampling on fire remains, (c) cleaning/sweeping or removal of materials, (d) using wood in a limited amount to fuel fires, (e) using an abundant amount of grasses, and (f) depositing organic remnants (bones, etc.) in secondary phosphates.

Ground-penetrating radar (GPR) using a $400-\mathrm{MHz}$ antenna (Fig. 20) indicated a bowl-like bedrock floor in the cave and revealed potential hearth features prior to excavations. A grid of 400-MHz reflection profiles was 
Table 14 Pottery use-alteration analysis form Mota, Tuwatey, and Gulo caves

\begin{tabular}{|c|c|c|c|c|c|c|c|c|}
\hline $\begin{array}{l}\text { Site } \\
\text { Unit level }\end{array}$ & Number & Interior treatment food residue & Wear & Pitting & Exterior treatment carbon & Wear & Pitting & Date (cal BP) \\
\hline \multicolumn{9}{|l|}{ Mota } \\
\hline ST2-2 & & 3 & 3 & & & 8 & & $1700 \pm 130$ \\
\hline ST2-3 & & 1 & 2 & & & 3 & & $2370 \pm 30$ \\
\hline ST2-4 & & & & 1 & & & 1 & \\
\hline TU3-1 & & & & 1 & & 2 & & \\
\hline TU3-2 & & & 1 & & 1 & 1 & 1 & $330 \pm 30$ \\
\hline TU3-3 & & 1 & & 1 & 1 & 4 & & \\
\hline TU3-4 & & 1 & & & & & & \\
\hline TU4-1 & & & 1 & & & & & \\
\hline TU4-2 & & & & & 1 & 1 & 1 & \\
\hline TU4-3 & & 4 & 6 & & 1 & 5 & 1 & $310 \pm 30$ \\
\hline TU4-4 & & & & & & 1 & & $3300 \pm 30$ \\
\hline TU5-2 & & & 1 & & & 2 & & \\
\hline TU5-3 & & & 3 & & & 6 & 1 & \\
\hline TU3, 5, 6-1 & & & 1 & & & 3 & & \\
\hline \multicolumn{9}{|l|}{ TU7-1 } \\
\hline \multicolumn{9}{|l|}{ Tuwatey } \\
\hline TU1-1 & & & & 1 & & & & \\
\hline TU1-4 & & 1 & & 1 & & & 1 & \\
\hline TU2-1 & & 1 & & & & & & \\
\hline TU2-2 & & & & & & & 1 & \\
\hline TU2-3 & & & & & 1 & & 1 & \\
\hline C7-1 & & & & & 2 & & & \\
\hline $\mathrm{C} 7-3$ & & 1 & & & 1 & & & \\
\hline $\mathrm{C} 7-5$ & & & 1 & & 1 & & & \\
\hline $\mathrm{C} 8-2$ & & & & & 2 & & & \\
\hline D8-1 & & 1 & & & 1 & & & \\
\hline M3-3 & & & 1 & & & & & \\
\hline M3-5 & & & & & 1 & & & \\
\hline M3-6 & & 1 & & & & & & $1900 \pm 30$ \\
\hline N3-4 & & 2 & & 1 spalling & & & & \\
\hline O2-6 & & & & & & 5 & & \\
\hline $\mathrm{O} 2-8$ & & & 1 & & & & & $1810 \pm 30$ \\
\hline \multicolumn{9}{|l|}{ Gulo } \\
\hline ST1-1 & & 2 & & & & & & \\
\hline ST1-4 & & 1 & & & & & 1 & \\
\hline
\end{tabular}

collected on the generally flat floor of the cave with lines spaced at $50 \mathrm{~cm}$, and reflections recorded to 35 nanoseconds (ns), which is about $1.1 \mathrm{~m}$ depth in two-way travel time (Conyers 2013). Maximum radar energy penetration was about $25 \mathrm{~ns}(80 \mathrm{~cm})$, with distinct attenuation of energy within the thicker sediment package at about
$20 \mathrm{~ns}(60 \mathrm{~cm})$ (Fig. 21). The sediment layers in the middle of the cave are generally horizontal (Fig. 22). There are very distinct areas of rock fall in the front and rear of the cave as well as on its sides where the ceiling is low, creating a "bowl" sediment package within the cave. The sediments within this bedrock-bounded bowl 


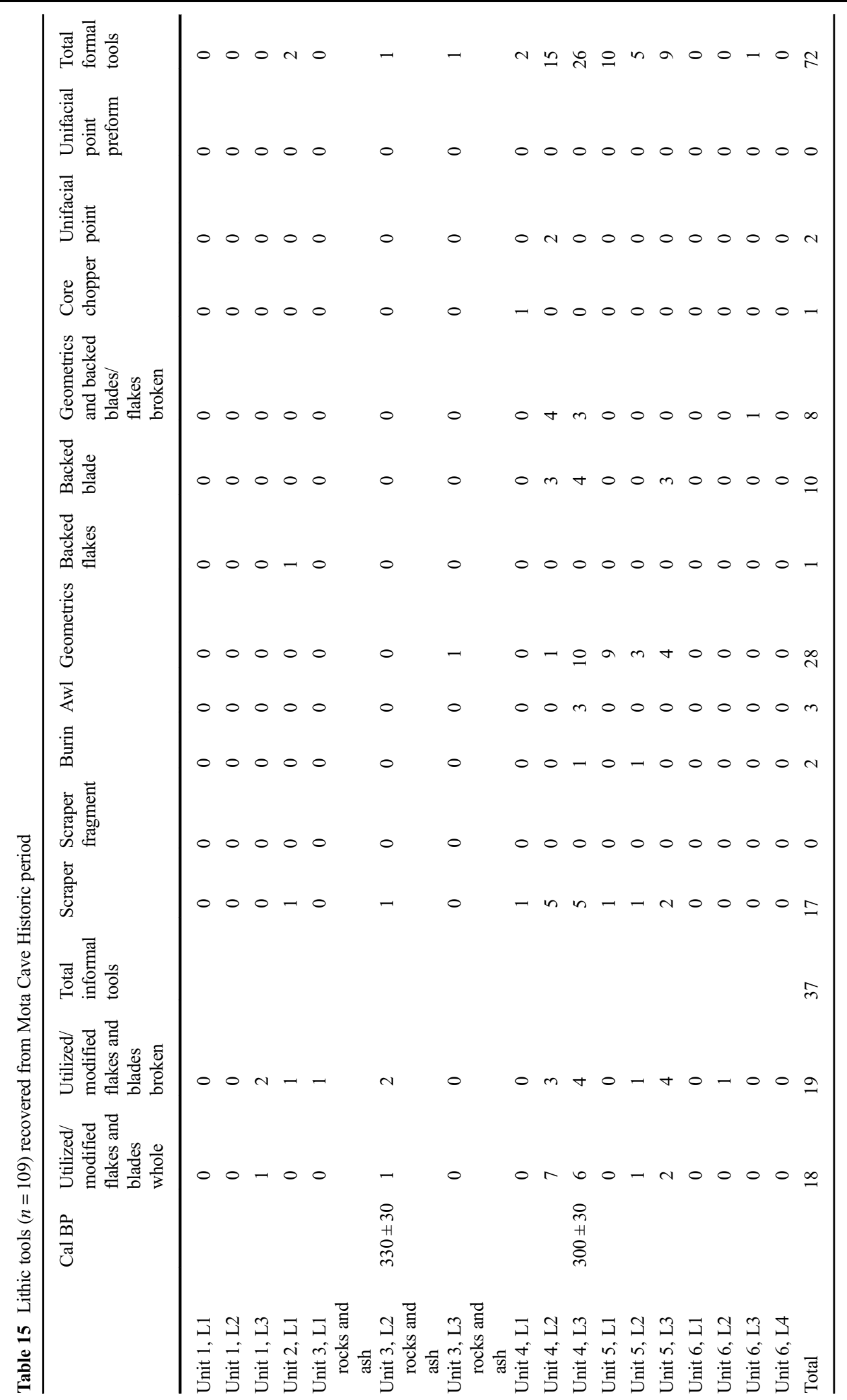


Table 16 Lithic cores and debitage $(n=281)$ recovered from Mota Cave Historic period

\begin{tabular}{|c|c|c|c|c|c|c|c|c|c|c|c|}
\hline & Cal BP & Cores & $\begin{array}{l}\text { Bipolar } \\
\text { core }\end{array}$ & $\begin{array}{l}\text { Bipolar core } \\
\text { fragment }\end{array}$ & $\begin{array}{l}\text { Broken core } \\
\text { fragment }\end{array}$ & Flakes & Blades & $\begin{array}{l}\text { Angular } \\
\text { waste }\end{array}$ & Resharpening & Broken & $\begin{array}{l}\text { Total } \\
\text { debitage }\end{array}$ \\
\hline Unit 1, L1 & & 0 & 0 & 0 & 0 & 0 & 0 & 0 & 0 & 0 & 0 \\
\hline Unit 1, L2 & & 0 & 0 & 0 & 0 & 0 & 0 & 0 & 0 & 0 & 0 \\
\hline Unit 1, L3 & & 0 & 0 & 0 & 0 & 0 & 0 & 0 & 0 & 1 & 1 \\
\hline Unit 2, L1 & & 0 & 0 & 0 & 0 & 5 & 0 & 0 & 0 & 1 & 6 \\
\hline Unit 3, L1 & & 0 & 0 & 0 & 0 & 0 & 0 & 0 & 0 & 0 & 0 \\
\hline Unit 3, L2 & $330 \pm 30$ & 0 & 0 & 0 & 0 & 1 & 0 & 2 & 3 & 9 & 15 \\
\hline Unit 3, L3 & & 0 & 0 & 0 & 0 & 7 & 0 & 0 & 1 & 8 & 16 \\
\hline Unit 4, L1 & & 0 & 0 & 0 & 1 & 0 & 0 & 1 & 0 & 0 & 1 \\
\hline Unit 4, L2 & & 1 & 0 & 0 & 0 & 6 & 0 & 4 & 2 & 8 & 20 \\
\hline Unit 4, L3 & $300 \pm 30$ & 2 & 0 & 0 & 0 & 11 & 0 & 54 & 2 & 56 & 123 \\
\hline Unit 5, L1 & & 0 & 0 & 0 & 0 & 16 & 1 & 1 & 1 & 22 & 41 \\
\hline Unit 5, L2 & & 0 & 0 & 0 & 0 & 3 & 0 & 4 & 0 & 1 & 8 \\
\hline Unit 5, L3 & & 1 & 0 & 0 & 0 & 3 & 0 & 4 & 5 & 8 & 20 \\
\hline Unit 6, L1 & & 1 & 0 & 0 & 0 & 4 & 0 & 0 & 0 & 8 & 12 \\
\hline Unit $6, \mathrm{~L} 2$ & & 0 & 0 & 0 & 0 & 0 & 0 & 0 & 1 & 2 & 3 \\
\hline Unit 6, L3 & & 0 & 0 & 0 & 0 & 5 & 1 & 2 & 0 & 0 & 8 \\
\hline Unit 6, L4 & & 0 & 0 & 0 & 0 & 0 & 0 & 0 & 1 & 0 & 1 \\
\hline Total & & 5 & 0 & 0 & 1 & 61 & 2 & 72 & 16 & 124 & 275 \\
\hline
\end{tabular}

exhibit a number of subtle concave upward reflections that are likely hearths, but could be other depressions of unknown origin (Fig. 21).

The shapes of hearths in GPR reflection profiles have been discovered in cave sediments elsewhere (Conyers 2016). When all GPR reflection profiles are resampled and a three-dimensional volume of reflections is created, the features and sediment package reflections can be sliced into horizontal packages and then visualized (Conyers 2013). The individual depth slices show high areas on the margins of the cave floor caused by rockfall, and there is sediment package within the bedrock "bowl" (Fig. 23). Within this sediment package, low amplitude reflections are interpreted as concentrations of hearths. Excavations and soil micromorphological studies in Tuwatey Cave subsequently revealed that the inhabitants constructed multiple hearth features (i.e., units TU1 L4 5, TU2 L4-5, J5 L6, and M3 L5-6), providing support for extensive controlled use of fire in several areas of the cave. Thirteen radiocarbon AMS dates for Tuwatey range from the Pre-Pottery period (5520-3230 cal BP) - units 1, 2, C7, J5 L4-10, two hearth features; Early Pottery period (1925-1820 cal BP)-M3, N2, N3, O2, and O3 L4-11, one possible hearth; and Historic period (492122 cal BP) - all units, levels 1-3 (Table 1).
Pre-Pottery Period and Earliest Occupation (5520 to 3230 Cal BP)

Hunters and gatherers occupied Tuwatey Cave ca. 5520 cal BP making this the earliest Holocene occupation in the Gamo Highlands. Inhabitants seemed to have used the cave for temporary shelter to sleep and a place to keep warm. Hence, they constructed multiple hearths and left very few material remains behind. The hunters and gatherers did not use the cave as a place to produce materials or to cook a large amount of foods, as the frequency and density of artifacts $\left(0.0000068\right.$ lithic per $\left.\mathrm{cm}^{3}\right)$ and ecofacts are not as prevalent as in Mota Cave. Furthermore, artifacts are widely scattered and only occur in units $1,2, \mathrm{C} 7$, and $\mathrm{J} 5$ located in the center of the cave. There is no evidence of domesticated animals or plants during this period. The majority of the faunal materials are unidentified to species, but they are either large or small bovids (Table 24). The deposits from this period consist of a large amount of ash and charcoal with only one definitive hearth (unit J5) associated with one side scraper, one resharpening flake, and one chopper core (see Table 24). In unit 1, level 4-5, a second possible hearth yielded no 


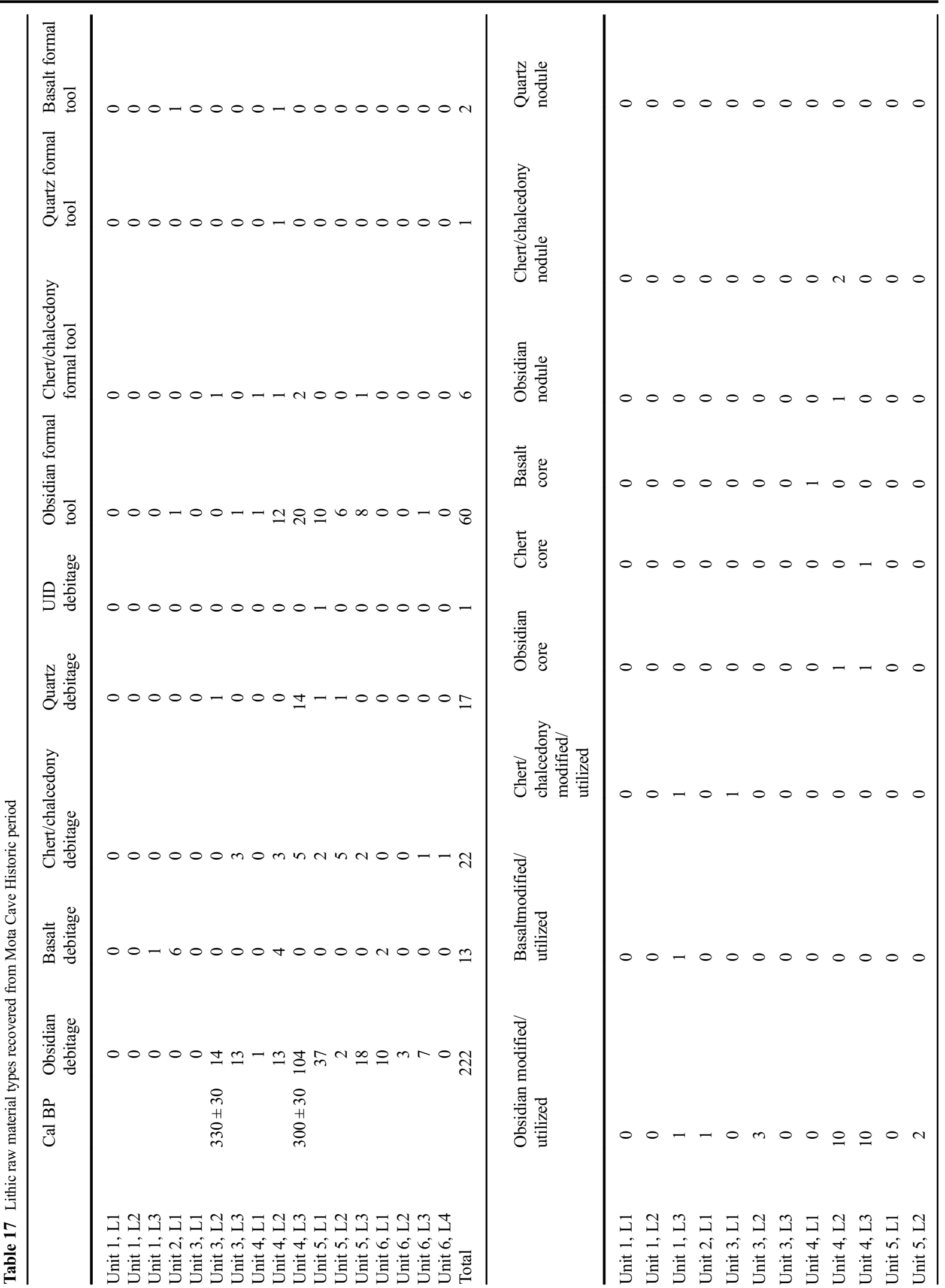


artifact. Overall, the earliest people at Tuwatey left few lithic artifacts. These consisted of one obsidian side scraper, four utilized/modified flakes, one obsidian awl, one obsidian geometric, three backed tools (two obsidian and one basalt), and 13 pieces of debitage (Tables 25 and 26). All of these show that limited activities relating to sewing, cutting, and scraping took place in the cave.

\section{Early Pottery Period and Middle Occupation (1920-1820 Cal BP)}

The earliest pottery at Tuwatey occurs later than at Mota and is associated with a hunting and gathering assemblage in the northeast corner of the cave with no specific feature. Pottery from Tuwatey Cave indicates that by 1925 BP potters were utilizing a range of surface treatments, polishing, burnishing, smudging, and red slip on both the interior and exterior surfaces (Table 9). While there is one sherd that has an associated date of $6000 \mathrm{BP}$, it seems most likely that this sherd is in this level due to some bioturbation and it is unlikely that people were using pottery at this early date. Most pottery, fauna, and lithics were concentrated in the back of the cave in units $\mathrm{N}$ and $\mathrm{M}$, with the heaviest concentrations in units $\mathrm{O} 2$ and O3. A possible hearth in unit M L5-6 consists of obsidian, basalt, chert, and quartz debitage and one obsidian scraper, two obsidian geometrics, and three obsidian modified flakes. There are also ceramics, a large bovid element, and two crab pincers (Tables 27, 28, and 29). Unlike the earlier occupation, the presence of chert and obsidian radial and pyramidal cores in the back units of the cave suggests that tools may have been made at the site. However, all of the debitage but four flakes are obsidian. So it seems that if the two chert cores were worked at the site, the knappers were very experienced and left little debitage, or the debitage was cast elsewhere at the site yet unexcavated, or discarded outside the site. All the formal and informal tools were made of obsidian, so chert core reduction at the site seems unlikely.

The Historic Period and Last Occupation (492-122 Cal $B P)$

Interviews with elders suggest a ritual use for the cave as well as use for protection during war during the Historic period. Compact floors were identified in the front and the center of the cave. Compact floors in units $\mathrm{C} 7$ and C8 (L1-3) near the front of the cave contained an 


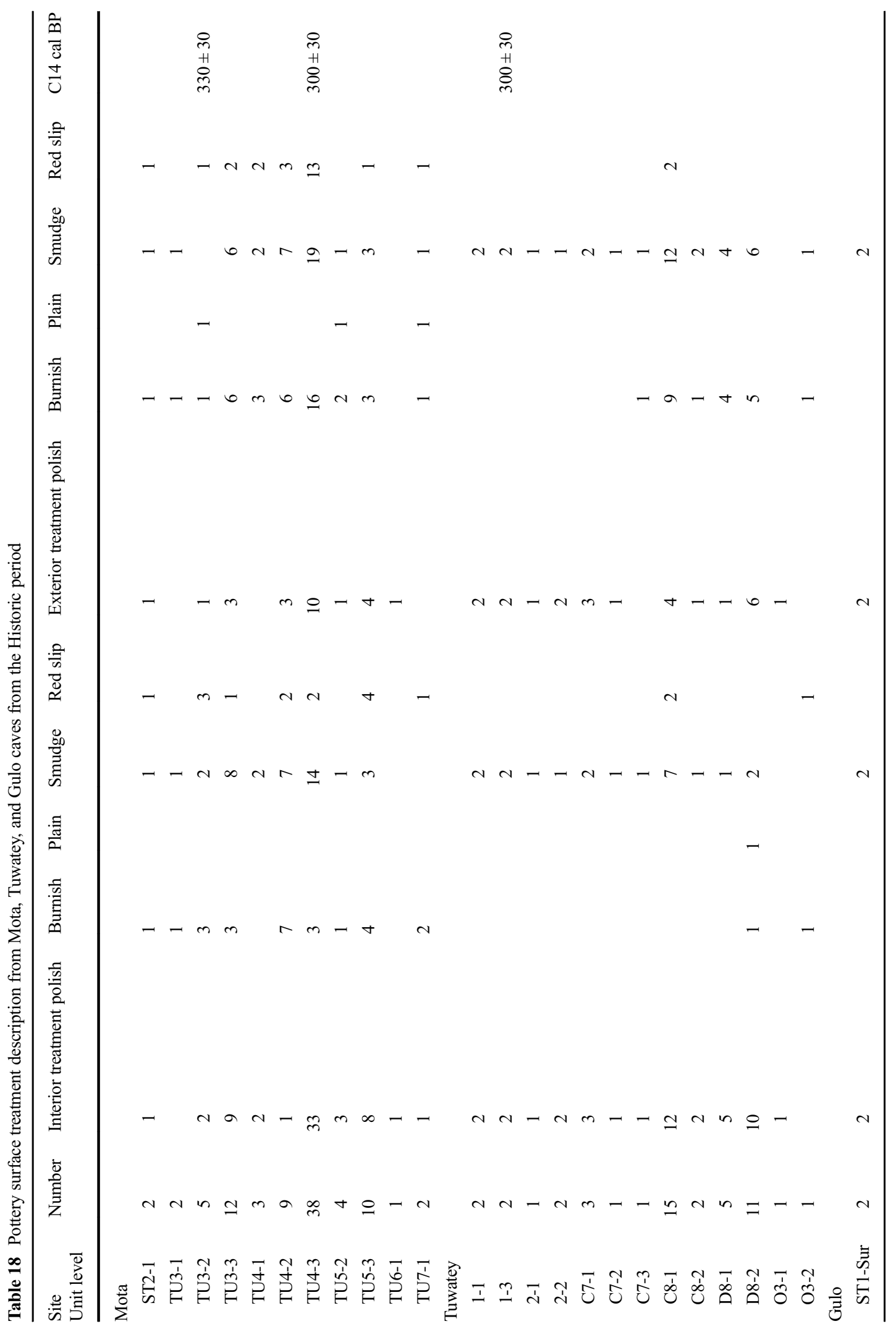


Table 19 Pottery rim descriptions from Mota and Tuwatey caves

\begin{tabular}{|c|c|c|c|c|c|c|c|c|c|c|}
\hline $\begin{array}{l}\text { Site } \\
\text { unit level }\end{array}$ & Rim type & $\begin{array}{l}\text { Type of } \\
\text { rim }\end{array}$ & $\begin{array}{l}\text { Rim } \\
\text { thickness } \\
(\mathrm{mm})\end{array}$ & $\begin{array}{l}\text { Radius } \\
(\mathrm{cm})\end{array}$ & $\begin{array}{l}\text { Diameter } \\
(\mathrm{cm})\end{array}$ & $\begin{array}{l}\text { Percent } \\
\text { of rim }\end{array}$ & $\begin{array}{l}\text { Temper } \\
\text { size } \\
(\mathrm{mm})\end{array}$ & Temper type & $\begin{array}{l}\text { Temper } \\
\text { composition } \\
(\%)\end{array}$ & $\begin{array}{l}\text { Date (cal } \\
\text { BP) }\end{array}$ \\
\hline \multicolumn{11}{|l|}{ Mota } \\
\hline Surface & Jar & Direct & 7.2 & 6 & 12 & 16 & $1 / 16-2.0$ & Quartz, basalt & 15 & \\
\hline ST2-3 & Unidentified & Direct & 12.7 & - & - & - & $1 / 16-1.0$ & Quartz, basalt & 5 & $2370 \pm 30$ \\
\hline TU3-1 & Bowl & Direct & 12.9 & 15 & 30 & 3 & $1 / 16-2.0$ & Quartz, basalt & 20 & \\
\hline TU3-1 & Plate & Convex & 15.8 & 25 & 50 & 2 & $1 / 16-2.0$ & Quartz, basalt & 15 & \\
\hline TU4-3 & Jar & Direct & 7.7 & 8 & 16 & 6 & $1 / 16-2.0$ & Quartz, basalt & 10 & $300 \pm 30$ \\
\hline TU6-1 & Bowl & Convex & 5.9 & 7 & 14 & 9 & $1 / 16-1 / 4$ & Quartz, basalt & 40 & \\
\hline TU7-1 & Bowl & Direct & 12.8 & 19 & 38 & 3 & $1 / 16-2.0$ & Quartz, basalt & 30 & \\
\hline \multicolumn{11}{|l|}{ Tuwatey } \\
\hline C7-1 & Jar & Direct & 5.9 & 7 & 14 & 9 & $1 / 16-1 / 4$ & Quartz, basalt & 3 & \\
\hline C8-1 & Jar & - & - & - & - & - & $1 / 16-2.0$ & Quartz, basalt & 10 & \\
\hline C8-1 & Jar & - & - & - & - & - & $1 / 16-2.0$ & Quartz, basalt & 40 & \\
\hline D8-2 & Jar & Direct & 7.3 & 4 & 8 & 12 & $1 / 16-1 / 4$ & Quartz, basalt & 10 & \\
\hline
\end{tabular}

abundance of ceramics, particularly jars, and half of the stone tools associated with this occupation include obsidian end and end-side scrapers, a modified flake, a geometric, and a backed blade (Tables 30 and 31). The adjacent unit D8 (L2-3) also produced many sherds, as well as a scraper and a backed blade. All four rims found in the upper levels are jar rims that have a polished and smudged surface treatment on both the exterior and interior (Tables 18 and 19). One jar has comb stamping (D8 L2) and the other has rippling (unit C8 L1). The rim sherds have only limited evidence of use-alteration attributes. There is occasional interior pitting and only one sherd has evidence of sooting (unit C8, L1). In this part of the cave, beginning around $492 \mathrm{cal} \mathrm{BP}$, we find the first evidence that people were eating domesticated plants at Tuwatey, as suggested by five barley seeds (Hordeum vulgare). There are also three indeterminate cereal seeds from level 7 in unit $\mathrm{C} 7$ associated with the compact floor. While this level has an Early Pre-Pottery date (Table 1), we have directly dated one of the five barley seeds to ca. 1416-1440 AD, an indication that the barley seed was likely moved to this level by bioturbation. Out of 28 flotation samples studied, only ten samples produced some identifiable plant remains, and from these, only 28 identifiable specimens were found. This is extremely sparse in comparative terms and tends to suggest that plant-based activities and/or context for charring of waste were only occasional within this cave. Nevertheless, the identified remains include barley, wheat, sorghum, finger millet, cotton, probably fruits of a Rhamnus shrub, and a few fragments of possible tubers (i.e., charred parenchyma tissue). Two barley grains and one cottonseed were subjected to AMS radiocarbon dating, and the dates fall between the late seventeenth century and early twentieth century AD (Tables 32 and 33).

A second compact surface in the center of the cave was identified at J5, level 2 . One backed blade and one flake were found here, but fauna and ceramics were absent. Parts of a wood string instrument were recovered from nearby unit 2 (L1 and 2) along with flakes, angular waste, utilized flakes and blade, and two cores (L1-3) as well as large bovid, suid, rodent, and crab remains (Table 34). In addition, a barley seed and a cottonseed (Gossypium sp.), both found in unit 1, level 2, date to 172 and 122 cal BP, respectively (Fig. 24). At the back of the cave, only a few artifacts were found in all the units and levels. For example, two sherds were present in $\mathrm{O} 3 \mathrm{~L} 1-2$, with one sherd having burnished surface and red slip on the interior and a burnished and smudged exterior. The other sherd has only polish on the exterior and interior. There is no evidence of use-alteration on either sherd. Also, a piece of iron slag and a few pieces of debitage (N3 L1) and two small ground stones (with worn surface), as well as rodent and crab remains (M3 L3), were recovered. (Table 35). No domesticated fauna has been recovered from Tuwatey Cave. 
Table 20 Faunal results from Mota Cave during the Historic period

\begin{tabular}{|c|c|c|c|c|c|c|c|c|c|c|c|c|c|}
\hline $\begin{array}{l}\text { Mota Cave GB20 unit } \\
\text { Level }\end{array}$ & $\begin{array}{l}\text { ST } 1 \\
\text { LV } 2\end{array}$ & $\begin{array}{l}\text { ST } 1 \\
\text { Lv } 3\end{array}$ & $\begin{array}{l}\mathrm{Tu} 3 \\
\mathrm{Lv} 2\end{array}$ & $\begin{array}{l}\text { Tu } 3 \\
\text { Lv } 3\end{array}$ & $\begin{array}{l}\mathrm{Tu} 4 \\
\mathrm{Lv} 1\end{array}$ & $\begin{array}{l}\mathrm{Tu} 4 \\
\mathrm{Lv} 2\end{array}$ & $\begin{array}{l}\mathrm{Tu} 4 \\
\mathrm{Lv} 3\end{array}$ & $\begin{array}{l}\mathrm{Tu} 5 \\
\mathrm{Lv} 1\end{array}$ & $\begin{array}{l}\text { Tu } 5 \\
\text { Lv2 }\end{array}$ & $\begin{array}{l}\text { Tu } 5 \\
\text { Lv } 3\end{array}$ & $\begin{array}{l}\text { Tu } 6 \\
\operatorname{Lv} 1\end{array}$ & $\begin{array}{l}\text { Tu } 6 \\
\text { Lv } 2\end{array}$ & $\begin{array}{l}\text { Tu } 6 \\
\text { Lv } 3\end{array}$ \\
\hline Human (Homo sapiens) & & & & & & 2 & & & & & & & \\
\hline Large bovid & & & 1 & 1 & & 3 & 3 & & & & & 1 & \\
\hline Cattle (Bos taurus) & & & 1 & & & & & & & & & & \\
\hline Sheep (Ovis aries)/goat (Capra hircus) & & & 3 & & 1 & 1 & 1 & & 1 & & & & \\
\hline Middle-sized bovid & 1 & & & & & 2 & 1 & & 1 & & & 1 & \\
\hline Small-sized bovid & & & & & & & 1 & 3 & & 3 & & 2 & \\
\hline Suid & & & & & 1 & 2 & 12 & & & & & & \\
\hline Middle-sized mammal & & 1 & & 1 & & 5 & 4 & 3 & & & & & \\
\hline Baboon (Papio anubis) & & & & & & & 1 & & & & & & \\
\hline Hyrax (Procavia capensis) & & & & & & 4 & & & & & & & \\
\hline Hare (Lepus capensis) & & & & & & & & & 2 & & & & \\
\hline Cane rat (Thryonomys swinderianus) & & & 2 & & & & 1 & & & & & & \\
\hline Small mammal & & & & & & & & 3 & & & & & \\
\hline Rodent & & & 5 & 5 & & & 1 & & 1 & 5 & & & \\
\hline Crab & & & 2 & 2 & 1 & & & & & 1 & & & \\
\hline
\end{tabular}

\section{Gulo Cave (Site GB17)}

Gulo Cave, situated at an elevation of 2,254 m above sea level, was occupied from 5380 to 1690 cal BP (Table 1) indicating it is contemporary with the PrePottery and Early Pottery periods at Mota and Tuwatey. The cave is located on the eastern escarpment of the Gamo Highlands facing the Rift Valley lakes. Gulo Cave is approximately $18 \mathrm{~m}$ in width and $7.5 \mathrm{~m}$ in depth. A preliminary shovel test, $75 \mathrm{~cm}$ wide, was placed near the entrance of the cave, just within the drip line (Fig. 25). The stratigraphy revealed a series of guano and phosphatized layers, $20 \mathrm{~cm}$ below the surface (Table 36 and Fig. 26). In the deepest deposits of Gulo Cave dating to $5380 \mathrm{BP}$, we recovered only one piece of chert angular waste. The richest deposit was level 4 dating to ca. 2020 BP, which included 20 pieces of chert angular waste and four ceramic body sherds (Table 9) dating to ca. 2250 BP. In the upper levels, dating to ca. $1600 \mathrm{BP}$, we recovered two sherds, two obsidian blades, and two pieces of chert angular waste, as well as three fauna elements (one large bovid and two unidentified elements), but no floral material was found. The preliminary testing of Gulo suggests that, with expanded excavations, it has potential for revealing further information about the Pre-Pottery and Early Pottery periods of the Gamo Highlands and the transition to food production.

Table 21 Archaeobotanical results from Mota Cave

\begin{tabular}{|c|c|c|c|c|c|c|c|c|}
\hline $\begin{array}{l}\text { Mota Cave GB20 unit } \\
\text { Level }\end{array}$ & $\begin{array}{l}\text { St } 2 \\
\text { Lv } 6\end{array}$ & $\begin{array}{l}\text { St } 2 \\
\text { Lv } 3\end{array}$ & $\begin{array}{l}\text { Tu } 3 \\
\text { Lv } 2\end{array}$ & $\begin{array}{l}\text { Tu } 3 \\
\text { Lv } 4\end{array}$ & $\begin{array}{l}\mathrm{Tu} 4 \\
\mathrm{Lv} 4\end{array}$ & $\begin{array}{l}\text { Tu } 4 \\
\text { Lv } 5\end{array}$ & $\begin{array}{l}\mathrm{Tu} 4 \\
\mathrm{Lv} 4\end{array}$ & $\begin{array}{l}\text { Tu } 5 \\
\text { Lv } 3\end{array}$ \\
\hline Sample \# (SS) & 6 & 3 & 107 & 109 & 113 & 115 & 113 & 117 \\
\hline Hordeum vulgare & & 1 & & & & & & \\
\hline Parenchyma fragments (tubers) & & & 2 & & 2 & & & \\
\hline Indeterminate seed/fragment & 1 & 1 & & & & & 1 & 1 \\
\hline Large indeterminate legume & & & & 1 & & & & \\
\hline Total plant macroremains & 1 & 2 & 2 & 1 & 2 & 0 & 1 & 1 \\
\hline Terrestrial mollusk & & & 1 & & & $\mathrm{x}$ & & \\
\hline Dung fragments & & & $\mathrm{x}$ & & & $\mathrm{x}$ & & \\
\hline
\end{tabular}




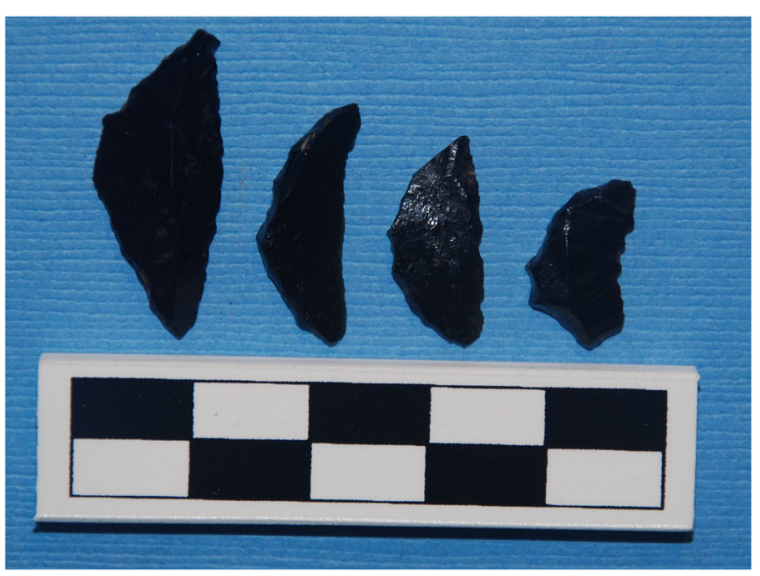

Fig. 15 Historic period microlithic crescents found in Mota Cave

However, due to the scant information we currently have about the site, it is not included in the comparative discussion below.

\section{Gamo Boreda Intersite Diversity}

Mota and Tuwatey caves were occupied during three contemporary time periods, which provide evidence for the local transition to food production: a PrePottery period ca. 5500-3200 BP, an Early Pottery period 2400-1600 BP, and a Historic period 500120 BP. Although the Boreda cave sites are contemporaneous, in close proximity to one another $(2.6 \mathrm{~km})$, and share similar altitudinal and ecological zones, the archaeological assemblages and features of Tuwatey and Mota caves suggest that the caves were utilized very differently. Tuwatey is a much larger cave with burning of the entire cave floor, which may have been a reaction to bat occupation

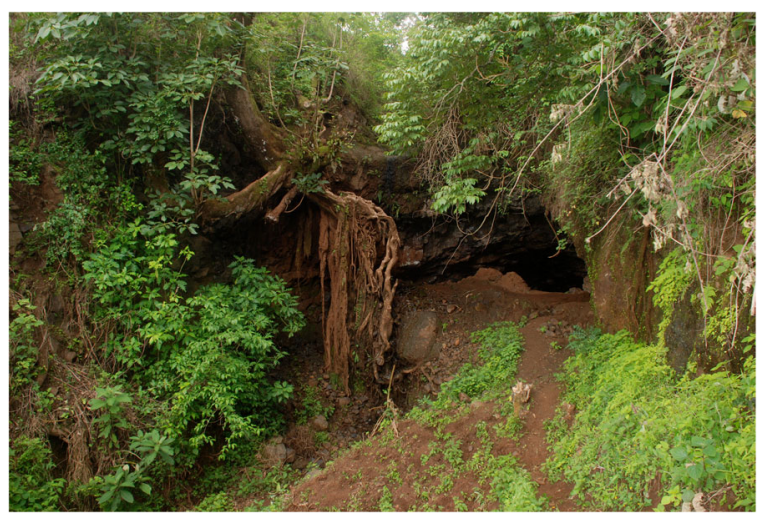

Fig. 16 Tuwatey Cave (layers of bat guano). The substantial bat guano deposits in Tuwatey suggest phases of prolonged abandonment of the cave. In addition, there is evidence of flooding during the Historic period in Tuwatey Cave. The density of artifacts at the two sites indicates that Mota was more intensively utilized than Tuwatey. The excavated volume from Tuwatey is three times greater than Mota, yet the number of artifacts recovered from Mota (3009 faunal elements, 120 pottery sherds, and 2431 lithics) is much greater than that found at Tuwatey (189 faunal elements, 72 sherds, and 99 lithics). The human remains from Mota indicate that the people were highland-adapted by $4500 \mathrm{BP}$, and while there may have been a stable population in the highlands, people could still have been highly mobile, occupying different cave sites seasonally, traveling to lowlands during dry seasons to take advantage of fish and wild game, or perhaps occupying yet unidentified open-air sites in the highlands.

The artifacts and features at the two sites suggest that Mota may have been utilized more for both everyday and ritual activities, and Tuwatey for short overnight stays. During all three periods at Mota, there is clear evidence that people were actively engaged in tool making, leatherworking, cutting and butchering, and cooking at formal hearths. In the Pre-Pottery period, Mota Cave was used as a mortuary site with a carefully constructed rock cairn laid over the Bayira burial. In contrast, the occupants of Tuwatey engaged in only a small amount of tool production and hide working in the early two periods at the site. Only in the later historic periods did people at Tuwatey leave behind compact floor structures. Tuwatey may have served as a place primarily for sleeping and the large amount of ash material may have been the result of possible preparation of the cave with grass fires to clear the cave of bats, porcupines, and/or hyenas so that people could sleep more soundly and safely.

A comparison of Mota and Tuwatey assemblages through time indicates that people produced and utilized primarily obsidian microlithic tools, particularly backed blades, about 5,000 years ago, but these began to dissipate in number ca. 2400 BP when the first pottery appeared. Subsistence in the region changed focus from a variety of small to large bovids and the addition of lake species to smaller montane bovids such as klipspringer and 
Fig. 17 Plan map of Tuwatey Cave and location of excavation areas
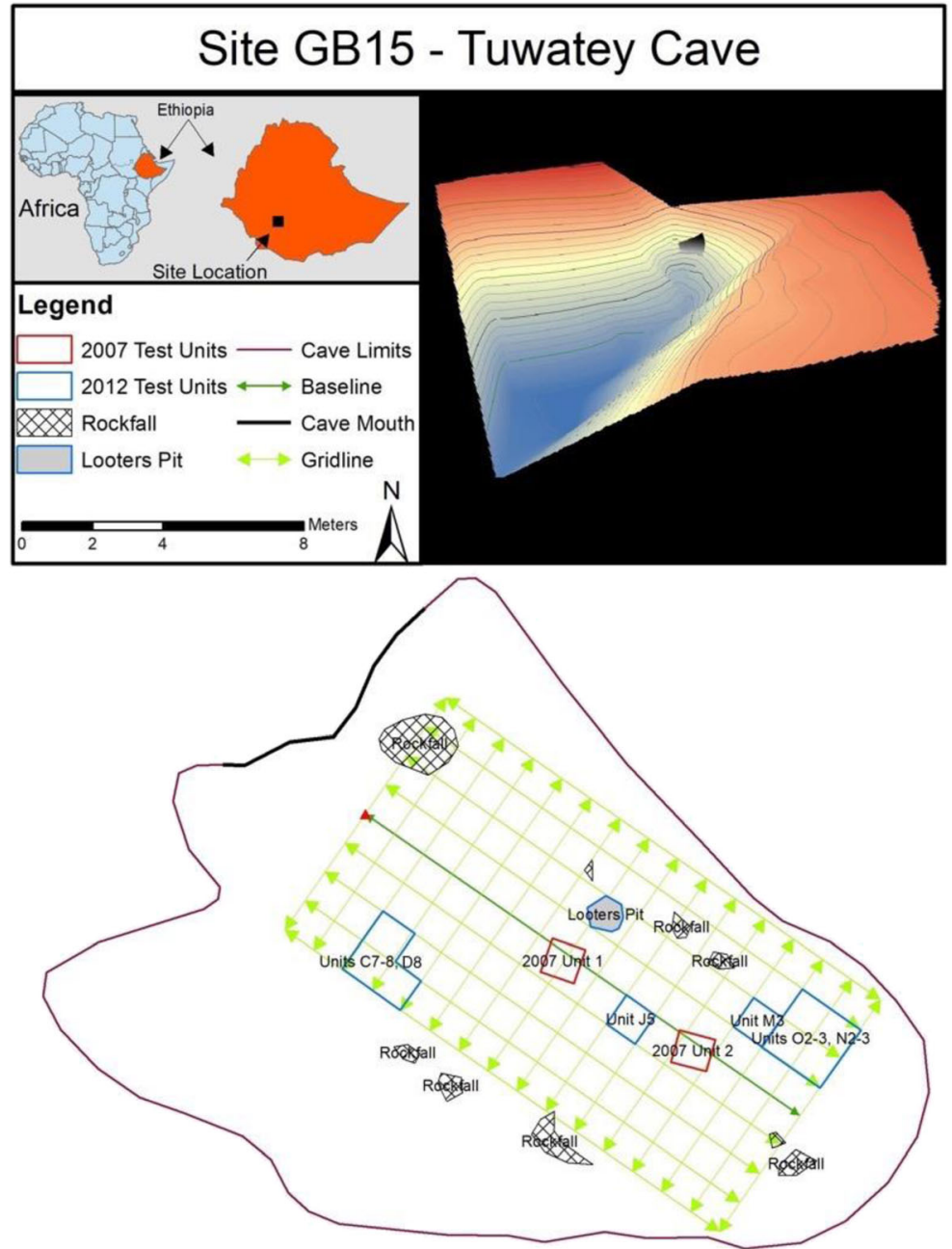

bushbuck by 2400 BP. Then, ca. 1700 BP, domesticated animals entered the archaeological sequence.

\section{Pre-Pottery Period (5500-3200 BP)}

During the Pre-Pottery period, hunters, gatherers, and fisher people were utilizing the caves. At Mota, people hunted small to large bovids, klipspringers, suids, monkeys, and hares with obsidian unifacial points. Burnt bone indicates that they cooked their game at the site. In addition, a tilapia bone at Mota suggests connections with the Rift Valley lakes to the east. The skeletal remains of Bayira suggest that this individual and likely the general population of the area were highland adapted, lactose intolerant, and consumed $\mathrm{C}_{4}$ indigenous African grasses (Gallego Llorente et al. 2015). In contrast, there was no direct evidence, in the form of microlithic points, for hunting at Tuwatey. At another site in southern Ethiopia about $60 \mathrm{~km}$ to the north, Mochena Borego, deposits dating ca. 4370 BP indicate hunting was concentrated on wild bovids, particularly African buffalo from the lowland plains (Lesur et al. 2007, 2014b) (Fig. 28). The authors hypothesize that these large animals may have been driven into the cul-de-sac at the end of the valley below the cave and then most likely were transported to the site already disarticulated, as carrying a carcass whole up the steep escarpment to the cave seems unlikely. In the far south in the lowland deposits of Yabello-4 dating prior to $4100 \mathrm{BP}$, people hunted Grevy's zebra, African buffalo, and oryx (Hundie 2001, p. 193).

Knappers at both Mota and Tuwatey seemed to prefer obsidian for tool production and people utilized stone 


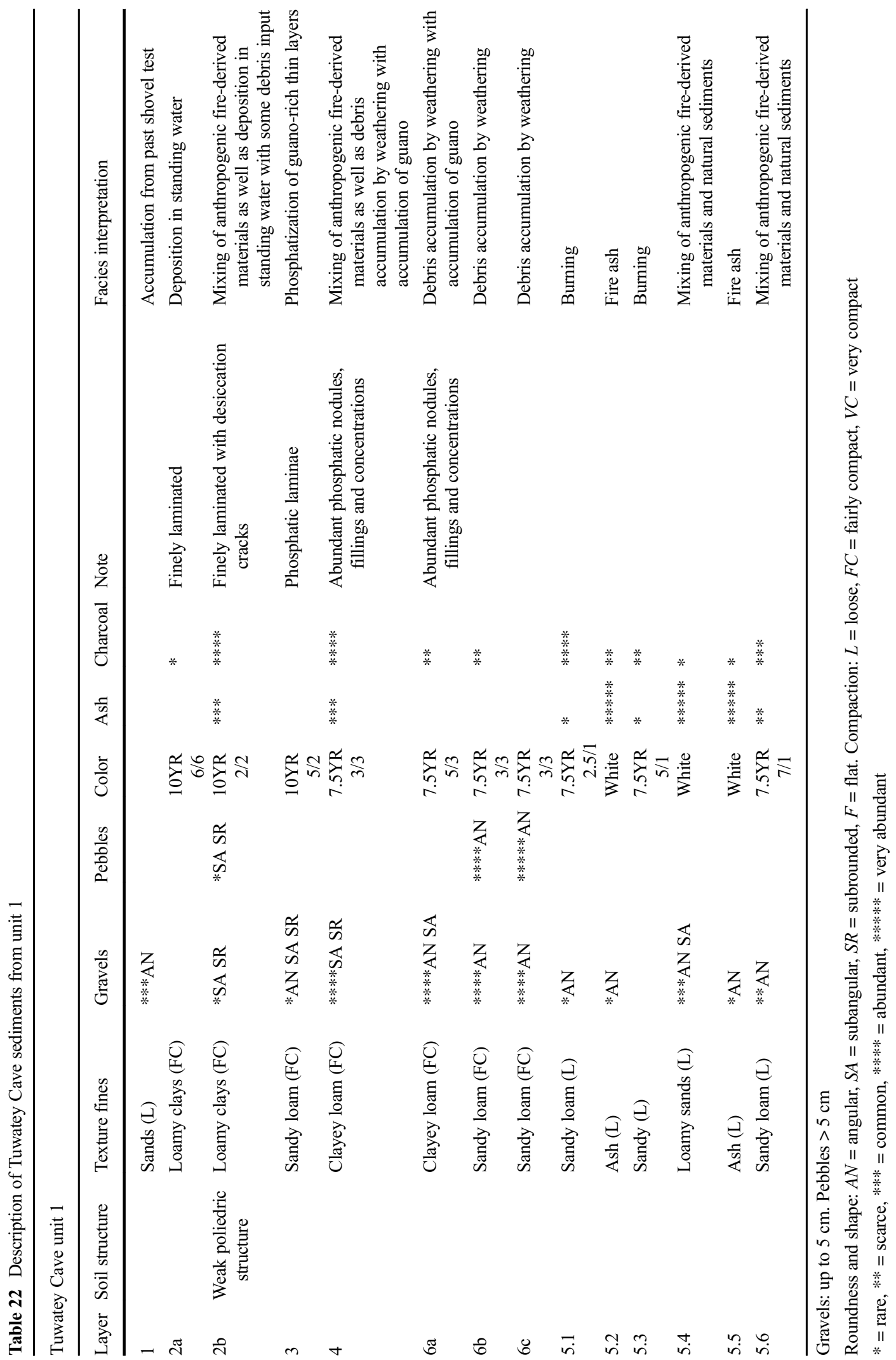




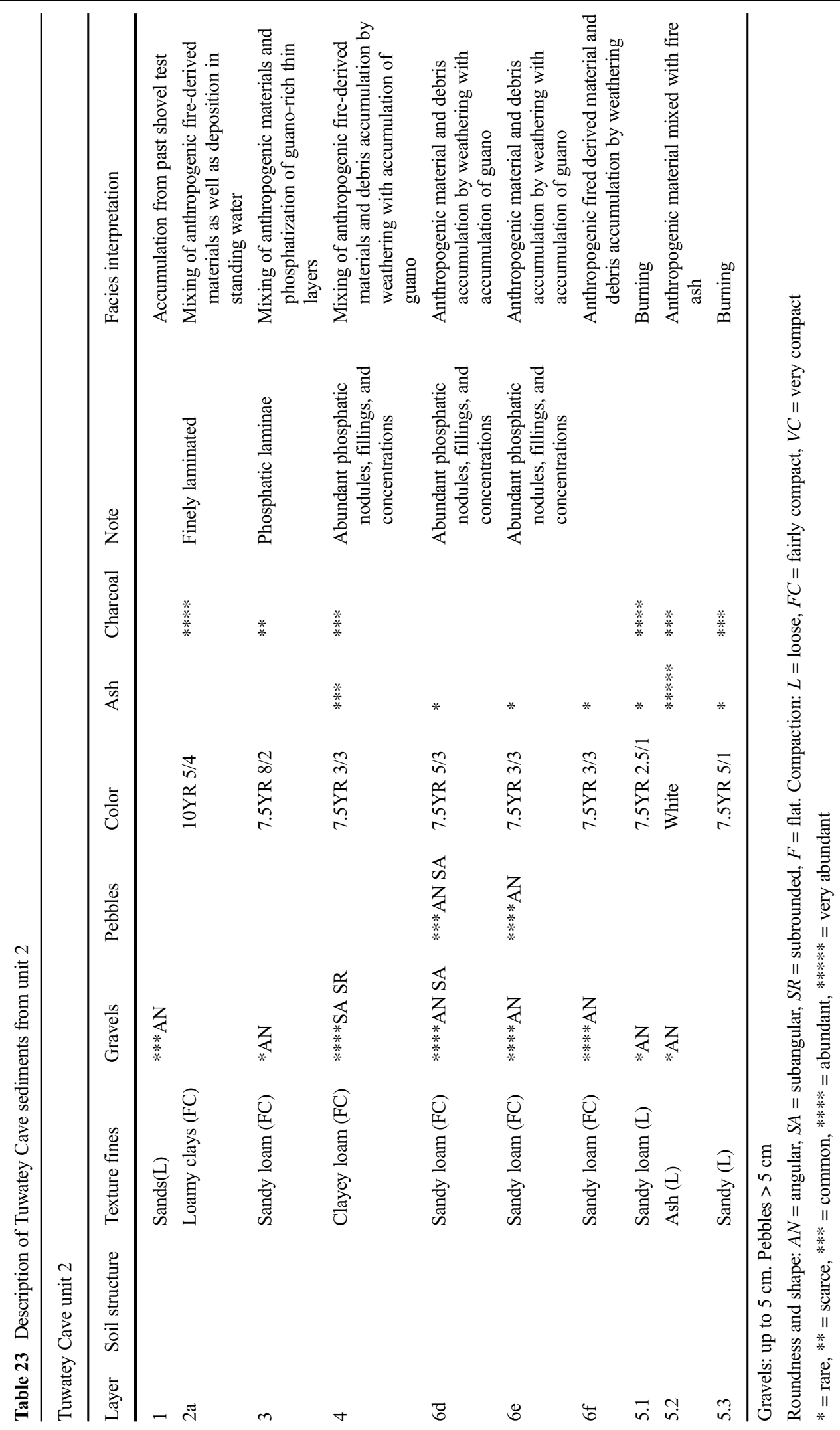




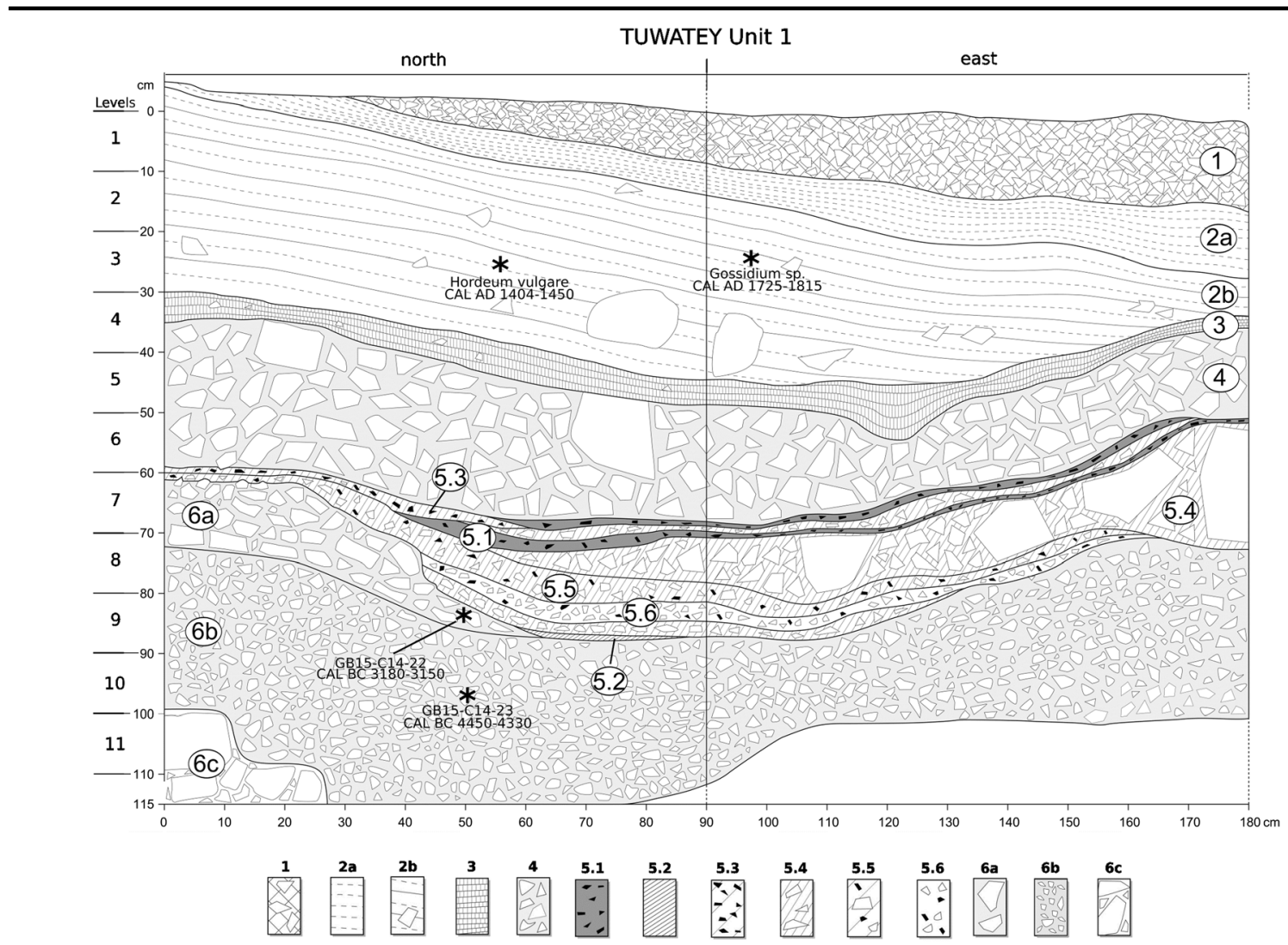

Fig. 18 Tuwatey Cave profile of unit 1

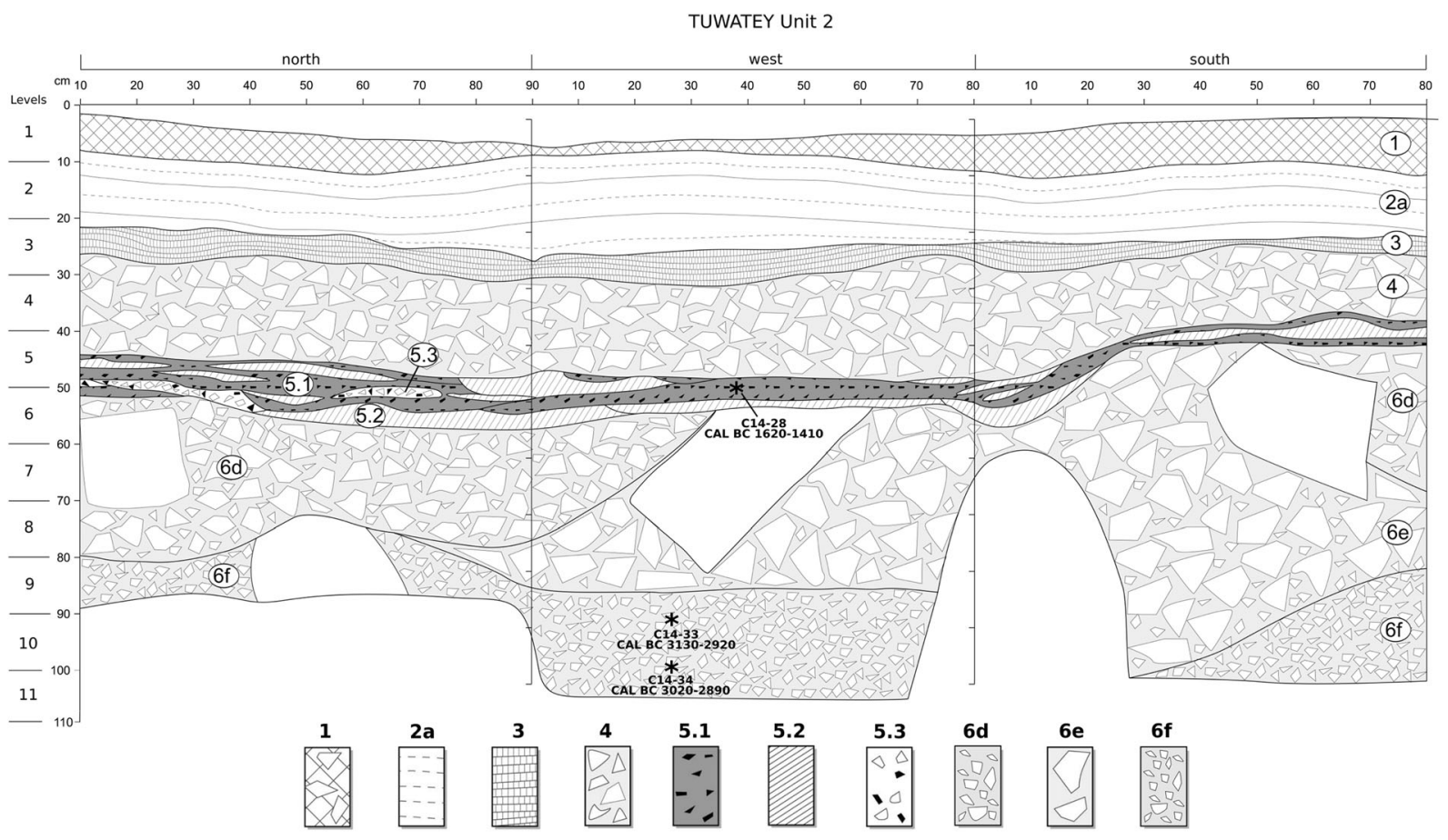

Fig. 19 Tuwatey Cave profile of unit 2 


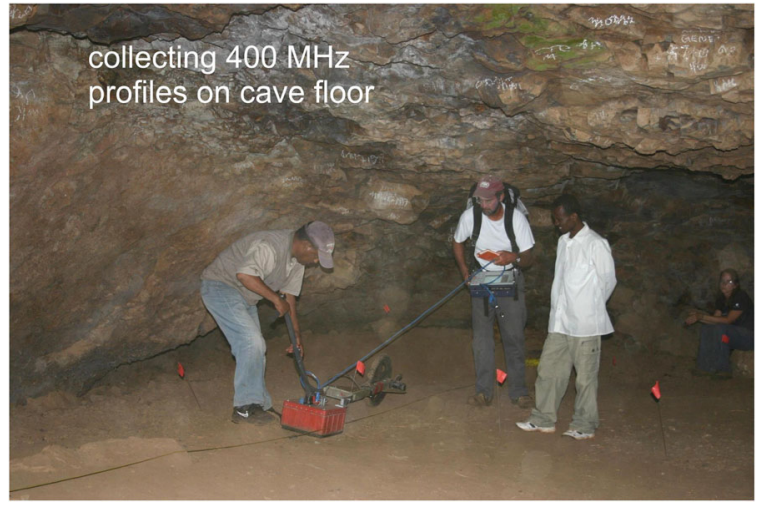

Fig. 20 Collecting 400-MHz GPR profiles at Tuwatey Cave

microliths for cutting, scraping, and sewing. Backed blades are particularly more prevalent than in the later periods at these sites, representing $18-25 \%$ of the formal tool assemblage. At Mota, the tools were likely associated with hide working, sewing, and meat and grass processing, as well as stone tool production. Large numbers of broken tools and flakes as well as scraper spurs suggest that novice toolmakers and users, perhaps

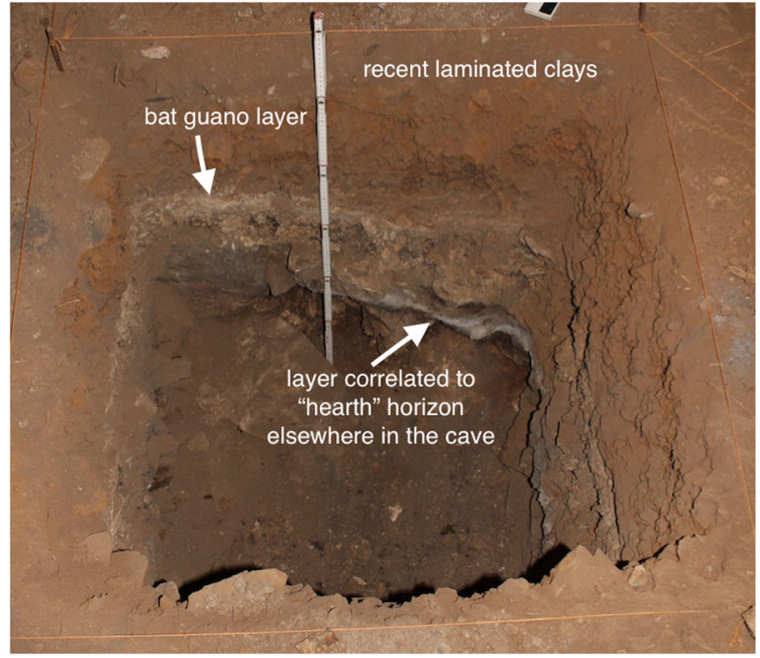

Fig. 22 Stratigraphy visible in GPR reflection profiles with the bat guano layer that attenuates radar energy visible and hearthbearing horizons below it

youth, occupied Mota Cave with experienced and adult knappers. The absence of cores at Tuwatey indicates that people were not engaged in tool production, but a

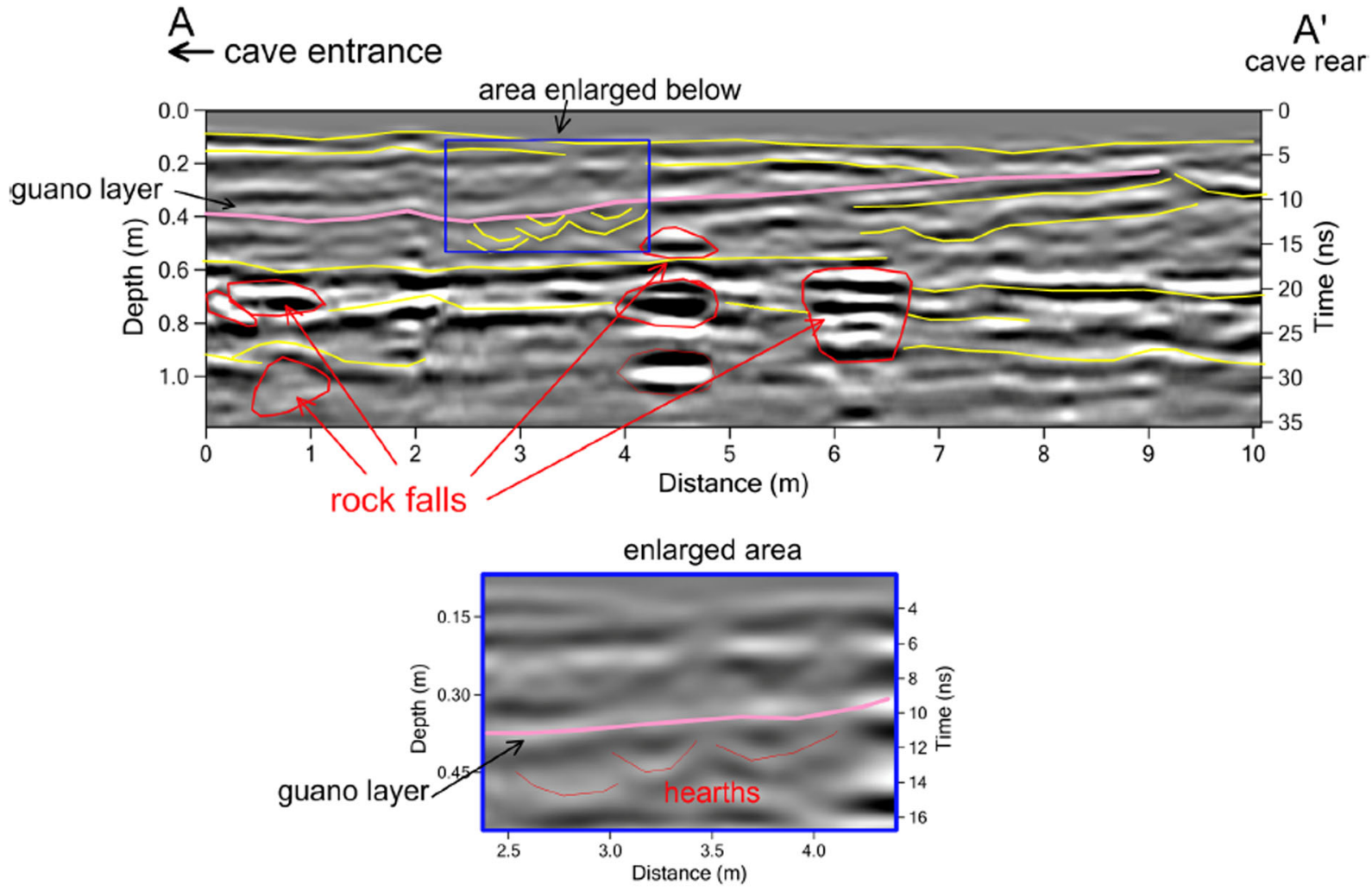

Fig. 21 Profile $\mathrm{A}-\mathrm{A}^{\prime}$ in the cave showing bedrock high areas near the entrance and at the rear, with a sediment package within. The sediment package contains a bat guano layer above 
0-5 ns:

$0-15 \mathrm{~cm}$

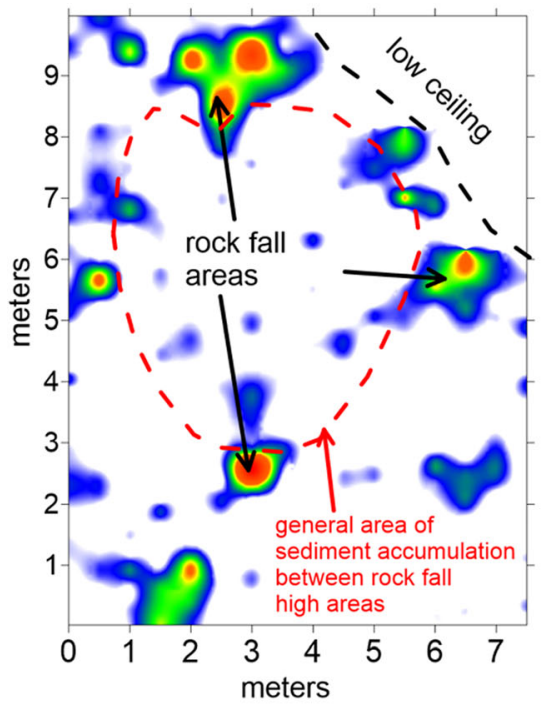

Fig. 23 GPR amplitude depth slices showing features of interest within the cave. The bounding roof fall high areas are visible in all slices, with the bowl of sediment in the middle containing

few lithics suggest they may have been sewing, cutting, and scraping on a limited basis. The absence of broken tools and spurs at Tuwatey suggests that only experienced tool users worked at the site. At Mota, people preferred to make and use formal tools (83\% of tools) fashioned from obsidian (94\%). In contrast, $64 \%$ of the tools made in Tuwatey were formal and these were made mostly from obsidian (86\%). Knappers at Mota and Tuwatey preferred obsidian for their unifacial points $(11 / 11,0 / 0)$, microliths $(110 / 120,2 / 4)$, scrapers $(39 / 40$, $1 / 1)$, and awls $(10 / 14,1 / 1)$. They also utilized basalt (Mota - four microliths, one awl; and Tuwatey-two microliths) and green and black/brown chert for tool production (Mota - six microliths, two awls, and one scraper). There is little published regional information available for comparison with the lithic assemblages of the Gamo Pre-Pottery Mid-Holocene sites. To the north

Table 24 Faunal descriptions from Tuwatey during the Pre-Pottery period

\begin{tabular}{lll}
\hline Tuwatey Cave GB 15 unit & Unit 2 & Unit 2 \\
\hline Level & 5 & 8 \\
Large bovid & 1 & 1 \\
\hline
\end{tabular}

of the Gamo region in Wolayta, at the site of Harurona, early deposits are dated to ca. 12,000 BP. Bachechi (2005) states that the obsidian geometric blade microlithic assemblage at Harurona resembles the end of the phase A of the Ethiopian Blade Tradition, which potentially dates from ca. $22000 \mathrm{BP}$ to $3500 \mathrm{BP}$ (Brandt 1980, 1982, 1986). At Mochena Borego, also in Wolayta, there is no detailed description of the Holocene lithics beyond the presence of obsidian segment (crescent) microliths dating to ca. 4370 BP (Gutherz et al. 2002). At Kumali in the Kafa region, Hildebrand et al. (2010) do not distinguish between Early and Late Holocene assemblages and instead indicate that the site's deposits dating from ca. 9426 to 1665 BP exhibit a dominance of chert debitage and cores, though there was a preference by knappers to use obsidian to produce microliths, and basalt and chert for scrapers.

The human burial, ochre, and geodes at Mota and ochre at Tuwatey suggest ritual activity that appears to be unique for this time period in southern Ethiopia. Ochre may have been used to color hides or as part of body ornamentation. The most significant ritual activity was associated with the remains of Bayira. He was carefully buried in a fetus-like position under a cairn facing west, with a geode and calcite underneath his leg. Heat-treated white-gray-pink chalcedony debitage was 


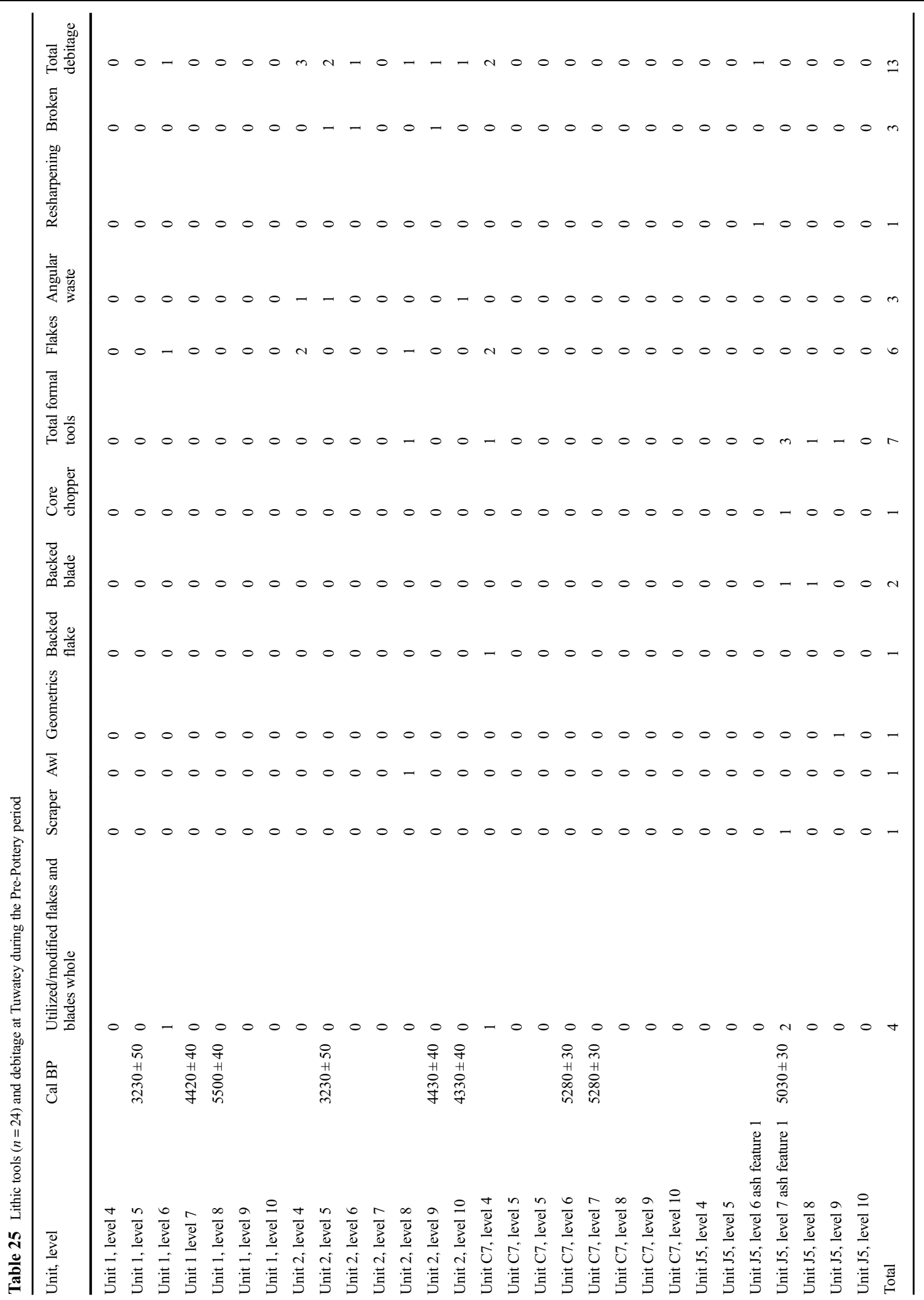


Table 26 Lithic raw material types $(n=24)$ Tuwatey during the Pre-Pottery period

\begin{tabular}{|c|c|c|c|c|c|c|c|c|c|c|}
\hline Unit, level & Cal BP & $\begin{array}{l}\text { Obsidian } \\
\text { debitage }\end{array}$ & $\begin{array}{l}\text { Basalt } \\
\text { debitage }\end{array}$ & $\begin{array}{l}\text { Chert/ } \\
\text { chalcedony } \\
\text { debitage }\end{array}$ & $\begin{array}{l}\text { Quartz } \\
\text { debitage }\end{array}$ & $\begin{array}{l}\text { Obsidian } \\
\text { formal } \\
\text { tool }\end{array}$ & $\begin{array}{l}\text { Basalt } \\
\text { formal } \\
\text { tool }\end{array}$ & $\begin{array}{l}\text { Obsidian } \\
\text { modified/ } \\
\text { utilized }\end{array}$ & $\begin{array}{l}\text { Basalt } \\
\text { modified/ } \\
\text { utilized }\end{array}$ & $\begin{array}{l}\text { Chert } \\
\text { modified/ } \\
\text { utilized }\end{array}$ \\
\hline Unit 1, level 4 & & 0 & 0 & 0 & 0 & 0 & 0 & 0 & 0 & 0 \\
\hline Unit 1 , level 5 & $3230 \pm 50$ & 0 & 0 & 0 & 0 & 0 & 0 & 0 & 0 & 0 \\
\hline Unit 1 , level 6 & & 0 & 0 & 0 & 0 & 0 & 0 & 0 & 0 & 1 \\
\hline Unit 1 level 7 & $4420 \pm 40$ & 0 & 0 & 0 & 0 & 0 & 0 & 0 & 0 & 0 \\
\hline Unit 1, level 8 & $5500 \pm 40$ & 0 & 0 & 0 & 0 & 0 & 0 & 0 & 0 & 0 \\
\hline Unit 1, level 9 & & 0 & 0 & 0 & 0 & 0 & 0 & 0 & 0 & 0 \\
\hline $\begin{array}{l}\text { Unit } 1, \text { level } \\
10\end{array}$ & & 0 & 0 & 0 & 0 & 0 & 0 & 0 & 0 & 0 \\
\hline Unit 2, level 4 & & 1 & 0 & 2 & 0 & 0 & 0 & 0 & 0 & 0 \\
\hline Unit 2, level 5 & $3230 \pm 50$ & 2 & 0 & 0 & 0 & 0 & 0 & 0 & 0 & 0 \\
\hline Unit 2, level 6 & & 0 & 0 & 0 & 1 & 0 & 0 & 0 & 0 & 0 \\
\hline Unit 2, level 7 & & 0 & 0 & 0 & 0 & 0 & 0 & 0 & 0 & 0 \\
\hline Unit 2, level 8 & & 1 & 0 & 0 & 0 & 1 & 0 & 0 & 0 & 0 \\
\hline Unit 2, level 9 & $4430 \pm 40$ & 0 & 0 & 0 & 0 & 0 & 0 & 1 & 0 & 0 \\
\hline $\begin{array}{l}\text { Unit } 2, \text { level } \\
\qquad 10\end{array}$ & $4330 \pm 40$ & 0 & 0 & 1 & 0 & 0 & 0 & 0 & 0 & 0 \\
\hline $\begin{array}{l}\text { Unit C7, level } \\
\quad 4\end{array}$ & & 0 & 1 & 0 & 0 & 0 & 1 & 0 & 0 & 0 \\
\hline $\begin{array}{l}\text { Unit } C 7 \text {, level } \\
5\end{array}$ & & 0 & 0 & 0 & 0 & 0 & 0 & 0 & 0 & 0 \\
\hline $\begin{array}{l}\text { Unit C7, level } \\
5\end{array}$ & & 0 & 0 & 0 & 0 & 0 & 0 & 0 & 0 & 0 \\
\hline $\begin{array}{l}\text { Unit C7, level } \\
\quad 6\end{array}$ & $5280 \pm 30$ & 0 & 0 & 0 & 0 & 0 & 0 & 0 & 0 & 0 \\
\hline $\begin{array}{l}\text { Unit C7, level } \\
7\end{array}$ & $5280 \pm 30$ & 0 & 0 & 0 & 0 & 0 & 0 & 0 & 0 & 0 \\
\hline $\begin{array}{l}\text { Unit C7, level } \\
\quad 8\end{array}$ & & 0 & 0 & 0 & 0 & 0 & 0 & 0 & 0 & 0 \\
\hline $\begin{array}{l}\text { Unit C7, level } \\
\quad 9\end{array}$ & & 0 & 0 & 0 & 0 & 0 & 0 & 0 & 0 & 0 \\
\hline $\begin{array}{l}\text { Unit C7, level } \\
\qquad 10\end{array}$ & & 0 & 0 & 0 & 0 & 0 & 0 & 0 & 0 & 0 \\
\hline $\begin{array}{l}\text { Unit J5, level } \\
\quad 4\end{array}$ & & 0 & 0 & 0 & 0 & 0 & 0 & 0 & 0 & 0 \\
\hline $\begin{array}{l}\text { Unit J5, level } \\
\quad 5\end{array}$ & & 0 & 0 & 0 & 0 & 1 & 0 & 0 & 0 & 0 \\
\hline $\begin{array}{l}\text { Unit J5, level } \\
6\end{array}$ & & 1 & 0 & 0 & 0 & 0 & 0 & 0 & 0 & 0 \\
\hline $\begin{array}{l}\text { Unit J5, level } \\
7 \text { ash } \\
\text { feature } 1\end{array}$ & $5030 \pm 30$ & 0 & 0 & 0 & 0 & 3 & 0 & 1 & 1 & 0 \\
\hline $\begin{array}{l}\text { Unit J5, level } \\
8 \text { ash } \\
\text { feature } 1\end{array}$ & & 0 & 0 & 0 & 0 & 1 & 0 & 0 & 0 & 0 \\
\hline $\begin{array}{l}\text { Unit J5, level } \\
\quad 9\end{array}$ & & 0 & 0 & 0 & 0 & 0 & 0 & 0 & 0 & 0 \\
\hline $\begin{array}{l}\text { Unit J5, level } \\
\quad 10\end{array}$ & & 0 & 0 & 0 & 0 & 0 & 0 & 0 & 0 & 0 \\
\hline Total & & 5 & 1 & 3 & 1 & 6 & 1 & 2 & 1 & 1 \\
\hline
\end{tabular}




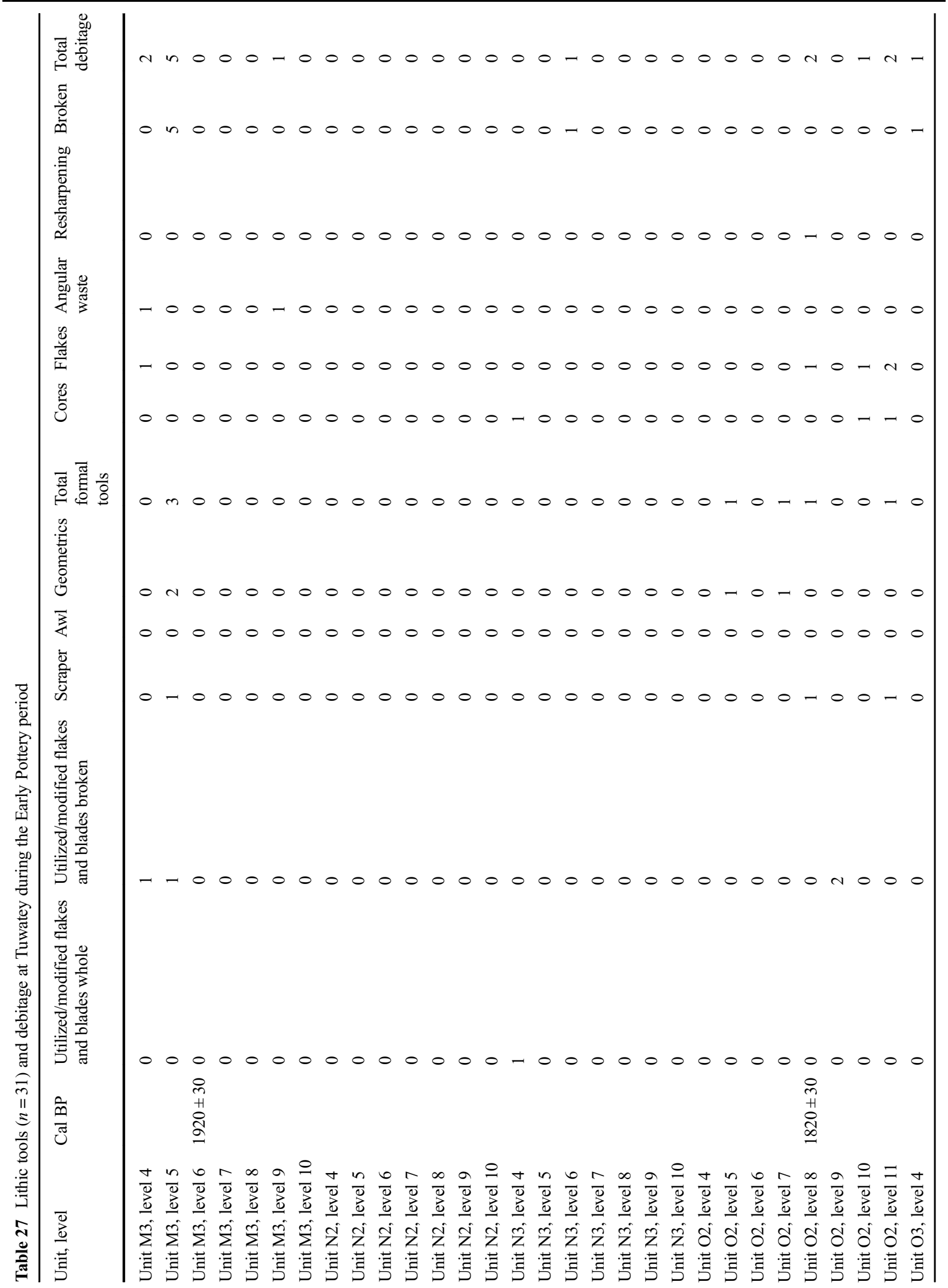


also deposited in the burial. In addition, there was a large accumulation of debitage near his head and debitage was also scattered within the rock cairn placed above him. This debitage, consisting of obsidian and green and red chert, may have had ritual significance.

\section{Early Pottery Period (2400-1600 BP)}

Pottery appears later at Tuwatey than at Mota, but at both sites, people continued to hunt wild bovids while incorporating some domesticated crops and animals into their diet. During the Early Pottery period at Mota, most activities focused near two circular rock features that are associated with wild and domesticated animal remains, shells, pottery, and lithics. At Tuwatey, most activities occurred in the back of the cave and were not associated with any particular feature. In the Gamo Highlands, the use of pottery preceded the consumption of domesticated plants and later domesticated animals. The low frequency of domesticated plants and animals at these cave sites and the persistence of hunting suggests that the Gamo highlanders were not fully dependent on domesticates. At this time, people were either involved in low-scale production of pottery and food cultivation, or they traded for these items.

The pottery from the caves is highly fragmented and consists mostly of small sherds with surface treatments characterized by polished, burnished, smudged, and red slip. Red slip does not occur in the present-day Gamo assemblages or from the historic open-air sites that we have excavated. The early pottery from Mota has burnishing on some of the exterior and interior surfaces, but there is no burnishing found on any of the Tuwatey sherds. During the Early Pottery period, the majority of the Mota sherds are found at the front of the cave. In Tuwatey, the highest density of the pottery is found on the side of the cave's central chamber, suggesting the storage of pottery or discarding of broken sherds along the cave wall. Comparing the Gamo pottery from other nearby regions such as the Nechisar Plains (Lesur et al. 2014b), Kafa (Hildebrand et al. 2010), and Yabello (Hundie 2001) indicates some similarities but also regional variations. The Nechisar Plain is located in the lowlands to the southeast of the Gamo Boreda region (Lesur et al. 2014b). The Nechisar pottery, consisting of only body sherds excavated from 
Table 28 Lithic raw materials from Tuwatey during the Early Pottery period

\begin{tabular}{|c|c|c|c|c|c|c|c|c|c|}
\hline & Cal BP & $\begin{array}{l}\text { Obsidian } \\
\text { debitage }\end{array}$ & $\begin{array}{l}\text { Basalt } \\
\text { debitage }\end{array}$ & $\begin{array}{l}\text { Chert/ } \\
\text { chalcedony } \\
\text { debitage }\end{array}$ & $\begin{array}{l}\text { Quartz } \\
\text { debitage }\end{array}$ & $\begin{array}{l}\text { Obsidian } \\
\text { formal tool }\end{array}$ & $\begin{array}{l}\text { Obsidian } \\
\text { modified/ } \\
\text { utilized }\end{array}$ & $\begin{array}{l}\text { Obsidian } \\
\text { core }\end{array}$ & $\begin{array}{l}\text { Chert } \\
\text { core }\end{array}$ \\
\hline Unit M3, level 4 & & 1 & 1 & 0 & 0 & 0 & 1 & 0 & 0 \\
\hline Unit M3, level 5 & & 2 & 0 & 1 & 1 & 3 & 1 & 0 & 0 \\
\hline Unit M3, level 6 & $1920 \pm 30$ & 0 & 0 & 0 & 0 & 0 & 0 & 0 & 0 \\
\hline Unit M3, level 7 & & 0 & 0 & 0 & 0 & 0 & 0 & 0 & 0 \\
\hline Unit M3, level 8 & & 0 & 0 & 0 & 0 & 0 & 0 & 0 & 0 \\
\hline Unit M3, level 9 & & 1 & 0 & 0 & 0 & 0 & 0 & 0 & 0 \\
\hline $\begin{array}{l}\text { Unit M3, level } \\
10\end{array}$ & & 0 & 0 & 0 & 0 & 0 & 0 & 0 & 0 \\
\hline Unit N2, level 4 & & 0 & 0 & 0 & 0 & 0 & 0 & 0 & 0 \\
\hline Unit N2, level 5 & & 0 & 0 & 0 & 0 & 0 & 0 & 0 & 0 \\
\hline Unit N2, level 6 & & 0 & 0 & 0 & 0 & 0 & 0 & 0 & 0 \\
\hline Unit N2, level 7 & & 0 & 0 & 0 & 0 & 0 & 0 & 0 & 0 \\
\hline Unit N2, level 8 & & 0 & 0 & 0 & 0 & 0 & 0 & 0 & 0 \\
\hline Unit N2, level 9 & & 0 & 0 & 0 & 0 & 0 & 0 & 0 & 0 \\
\hline $\begin{array}{l}\text { Unit N2, level } \\
10\end{array}$ & & 0 & 0 & 0 & 0 & 0 & 0 & 0 & 0 \\
\hline Unit N3, level 4 & & 0 & 0 & 0 & 0 & 0 & 1 & 0 & 1 \\
\hline Unit N3, level 5 & & 0 & 0 & 0 & 0 & 0 & 0 & 0 & 0 \\
\hline Unit N3, level 6 & & 1 & 0 & 0 & 0 & 0 & 0 & 0 & 0 \\
\hline Unit N3, level 7 & & 0 & 0 & 0 & 0 & 0 & 0 & 0 & 0 \\
\hline Unit N3, level 8 & & 0 & 0 & 0 & 0 & 0 & 0 & 0 & 0 \\
\hline Unit N3, level 9 & & 0 & 0 & 0 & 0 & 0 & 0 & 0 & 0 \\
\hline $\begin{array}{l}\text { Unit N3, level } \\
10\end{array}$ & & 0 & 0 & 0 & 0 & 0 & 0 & 0 & 0 \\
\hline Unit O2, level 4 & & 0 & 0 & 0 & 0 & 0 & 0 & 0 & 0 \\
\hline Unit O2, level 5 & & 0 & 0 & 0 & 0 & 1 & 0 & 0 & 0 \\
\hline Unit O2, level 6 & & 0 & 0 & 0 & 0 & 0 & 0 & 0 & 0 \\
\hline Unit O2, level 7 & & 0 & 0 & 0 & 0 & 1 & 0 & 0 & 0 \\
\hline Unit O2, level 8 & $1820 \pm 30$ & 1 & 1 & 0 & 0 & 1 & 0 & 0 & 0 \\
\hline Unit O2, level 9 & & 0 & 0 & 0 & 0 & 0 & 2 & 0 & 0 \\
\hline $\begin{array}{l}\text { Unit O2, level } \\
10\end{array}$ & & 1 & 0 & 0 & 0 & 0 & 0 & 0 & 1 \\
\hline $\begin{array}{l}\text { Unit O2, level } \\
\qquad 11\end{array}$ & & 2 & 0 & 0 & 0 & 1 & 0 & 1 & 0 \\
\hline Unit O3, level 4 & & 1 & 0 & 0 & 0 & 0 & 0 & 0 & 0 \\
\hline Unit O3, level 5 & & 0 & 0 & 0 & 0 & 0 & 0 & 0 & 0 \\
\hline Unit O3, level 6 & & 0 & 0 & 0 & 0 & 1 & 0 & 0 & 0 \\
\hline Unit O3, level 7 & & 0 & 0 & 0 & 0 & 0 & 0 & 0 & 0 \\
\hline Unit O3, level 8 & & 0 & 0 & 0 & 0 & 0 & 0 & 0 & 0 \\
\hline Unit O3, level 9 & & 0 & 0 & 0 & 0 & 0 & 0 & 0 & 0 \\
\hline $\begin{array}{l}\text { Unit O3, level } \\
\qquad 10\end{array}$ & & 0 & 0 & 0 & 0 & 0 & 0 & 0 & 0 \\
\hline Total & & 10 & 2 & 1 & 1 & 8 & 5 & 1 & 2 \\
\hline
\end{tabular}


Table 29 Faunal descriptions from Tuwatey during the Early Pottery period

\begin{tabular}{|c|c|c|c|c|c|c|c|c|c|c|c|c|c|c|c|c|c|}
\hline $\begin{array}{l}\text { Tuwatey Cave GB } 15 \text { unit } \\
\text { Level }\end{array}$ & $\begin{array}{l}\text { M3 } \\
5\end{array}$ & $\begin{array}{l}\text { M3 } \\
6\end{array}$ & $\begin{array}{l}\text { M3 } \\
7\end{array}$ & $\begin{array}{l}\mathrm{N} 2 \\
4\end{array}$ & $\begin{array}{l}\text { N3 } \\
4\end{array}$ & $\begin{array}{l}\mathrm{N} 3 \\
5\end{array}$ & $\begin{array}{l}\mathrm{O} 2 \\
4\end{array}$ & $\begin{array}{l}\mathrm{O} 2 \\
5\end{array}$ & $\begin{array}{l}\mathrm{O} 3 \\
6\end{array}$ & $\begin{array}{l}\mathrm{N} 2 \\
1\end{array}$ & $\begin{array}{l}\mathrm{N} 2 \\
2\end{array}$ & $\begin{array}{l}\mathrm{N} 3 \\
2\end{array}$ & $\begin{array}{l}\mathrm{O} 2 \\
1\end{array}$ & $\begin{array}{l}\mathrm{O} 2 \\
2\end{array}$ & $\begin{array}{l}\mathrm{O} 2 \\
3\end{array}$ & $\begin{array}{l}\mathrm{O} 3 \\
1\end{array}$ & $\begin{array}{l}\mathrm{O} 3 \\
3\end{array}$ \\
\hline Human (Homo sapiens) & & & & & & & & & & 1 & 1 & & & & & & \\
\hline Large bovid & & 1 & & 2 & 1 & 1 & & & & & & & & & & 1 & 1 \\
\hline Small-sized bovid & & & 1 & & & & & & & & 1 & 1 & 1 & & & & \\
\hline Rodent & & & 1 & & & & & & 1 & 1 & 1 & & & 1 & 1 & 1 & \\
\hline Bat & & & & & & & 9 & 1 & & & & & & & & 1 & \\
\hline Crab & 2 & & & & & & 1 & & & & & & & & & & 1 \\
\hline
\end{tabular}

Mome Cave, has stylistic traits including comb stamping with impressed lines or short nail impressions. However, the Nechisar vessels have thick walls and are heavily tempered with large mica suggesting that populations using the Mome Cave were producing locally made pottery. The decorative traits from the Yabello area also have comb stamping, but there is no indication of a red slip on the ceramics (Hundie 2001). The Kafa area to the northwest of the Gamo has pottery consisting of only body sherds with decorative motifs (i.e., herringbone and parallel incisions), and the slip has mica temper (Hildebrand et al. 2010). In the Gamo region, comb stamping and rippling near the rim do not occur on pottery until the Historic period.

As people were utilizing pottery for the first time, they also began to consume barley in this region as evident in Mota where a single barley seed dated to ca. $2400 \mathrm{BP}$ was found. Phytoliths analysis is ongoing but offers a potential method for identifying the presence of enset (Ensete ventricosum). The only other region nearby with similar dates for the adoption of domesticated plants is Kafa, where at Kumali rockshelter possible evidence of wild or domesticated enset or a domesticated Musa sp. was found in addition to two partial coffee seeds dating to $1740 \mathrm{BP}$ (Hildebrand et al. 2010). The Early Pottery people primarily depended on hunting as the source of their meat protein, with an increased reliance on more medium and small bovids, including bushbuck and klipspringer. In the later phase of the Early Pottery period, they added domesticated animals to their food resources. Domesticated cattle (Bos taurus) and sheep or goat were consumed at Mota ca. 1600 BP, representing $4 \%$ of the assemblage. A large portion (44\%) of the fauna assemblage at Mota were burned and were found in hearth and ash deposits indicating cooking of meat on the bone. This contrasts with activities at Tuwatey Cave, where no charring on wild or domesticated animal bone has been found. The domesticated fauna found at Mota is contemporaneous with similar fauna from the Kafa region and predates animal domesticates from Mochena Borago in the nearby Wolayta region by a millennium (Hildebrand et al. 2010; Lesur et al. 2014a). At Yabello shelter sites in the lowlands, cattle and sheep appear sometime between 4100 and 1990 BP, while wild animals such as Grevy's zebra, dik-dik, hartebeest, warthog, and eland continue to be hunted (Hundie 2001, p. 100, 113-114, 134-135, 195-197).

At both Mota and Tuwatey, people were engaged in cutting, sewing, and leather scraping activities with microlithic obsidian tools that have an increasingly standardized morphology during the Early Pottery period. A comparison of the breadth/length and thickness/ length ratio of the geometric tools through time at Mota suggests that there is increased standardization (Fig. 27). At both sites, there is a slight increase in the portion of scraper tools and a reduction in backed blades. Particularly at Tuwatey, a substantial decrease in the use of utilized and modified flakes and blades is evident (from $37 \%$ down to $8 \%$ ). People at Mota and Tuwatey sites primarily produced almost all their tools with obsidian, as this rock type accounts for $95 \%$ and $81 \%$ of the entire lithic assemblages, respectively. At Tuwatey, this was a substantial change because only $54 \%$ of the assemblage was obsidian during the previous period. In addition, $41 \%$ of the lithic assemblage at Tuwatey consists of tools compared to $8 \%$ at Mota. There is a larger amount of debitage at Mota ( $91 \%$ of assemblage) compared to Tuwatey (49\% of assemblage). This implies that people were making tools at Mota. The large amount of debitage in association with broken tools and cores further suggests novice toolmakers and users at Mota. Under one of the hearths at this site, people placed 


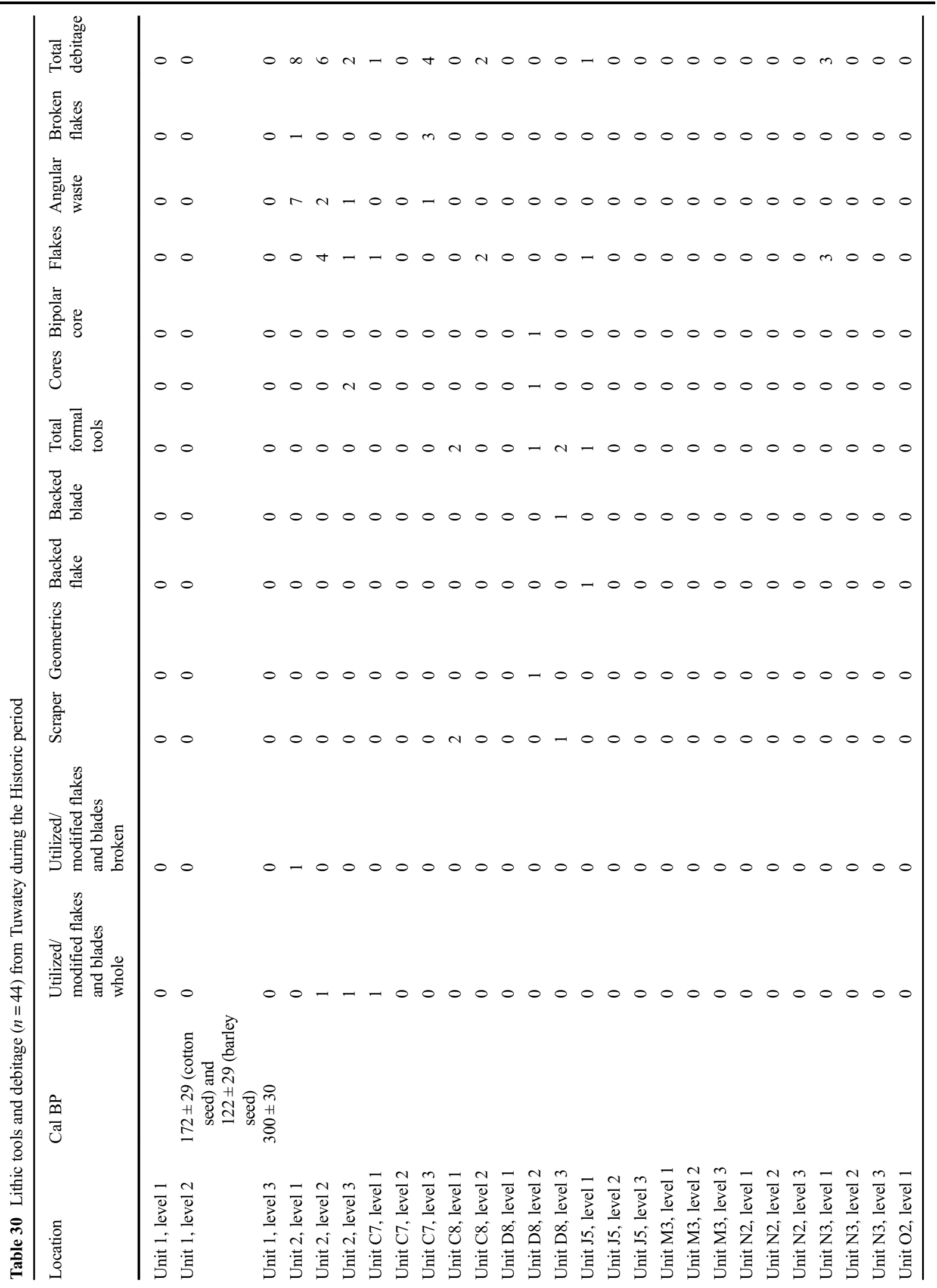


broken tools, cores, and debitage, which may have been used as an insulator or to secure sharp waste away from their feet.

Historic Period (500-120 BP)

Elders in the Gamo Highlands identified Mota and Tuwatey caves as locations for ritual offerings to ancestral and nature spirits and as places of refuge during conflicts with the Italian colonists and the Ethiopian state in the Historic period. At Mota, the front of the cave yielded evidence for serving vessels, vessels for beer or dairy products, and domestic fauna all associated with potential ritual activities. At Tuwatey, there are two compact surfaces with indications that people also were engaged in ritual activities. The compact surface at the front of the cave is associated with ceramic jars, barley, and a few obsidian tools. A second compact surface is located in the center of the cave in association with a few lithics, but no fauna or ceramics. Nearby, parts of a wood string instrument, wild fauna, barley, and cotton were recovered. The deposits at the back of Mota and Tuwatey support oral histories that indicate possible use for hiding in the times of conflict and insecurity. At Mota, there are the remains of small and medium bovids, tubers, and cooking pottery, as well as stone tools for hide scraping and cutting activities. While at Tuwatey, the few artifacts include rodent and crab remains, two small ground stones, iron slag, and a small amount of pottery.

At Mota and Tuwatey, people consumed both domesticated and wild fauna and engaged in scraping, sewing, and cutting activities. Stone tool production continued with obsidian as the preference for tool production at Mota $(83 \%$ of assemblage, two chert scrapers and four chert geometrics) compared to Tuwatey where people utilized more diversified raw materials including obsidian (58\%), chert (37\%), and quartz (4\%). Indeed, across the southern Ethiopian highlands, people persisted in making microliths as is evident at the eighteenth-century Kafa sites (Hildebrand et al. 2010) and the Mome Gongolo sites located in the lowlands between Lakes Abaya and Chamo to the east of the Gamo Highlands (Lesur et al. 2014b).

The stylistic attributes, form, and use-alteration studies of ceramics suggest different ceramic traditions at the two sites. Comb stamping and appliqué 
Table 31 Lithic raw material from Tuwatey during the Historic period

\begin{tabular}{|c|c|c|c|c|c|c|c|c|c|}
\hline & Cal BP & $\begin{array}{l}\text { Obsidian } \\
\text { debitage }\end{array}$ & $\begin{array}{l}\text { Chert/ } \\
\text { chalcedony } \\
\text { debitage }\end{array}$ & $\begin{array}{l}\text { Quartz } \\
\text { debitage }\end{array}$ & $\begin{array}{l}\text { Obsidian } \\
\text { formal } \\
\text { tool }\end{array}$ & $\begin{array}{l}\text { Obsidian } \\
\text { modified/ } \\
\text { utilized }\end{array}$ & $\begin{array}{l}\text { Chert } \\
\text { modified/ } \\
\text { utilized }\end{array}$ & $\begin{array}{l}\text { Obsidian } \\
\text { core }\end{array}$ & $\begin{array}{l}\text { Chert } \\
\text { core }\end{array}$ \\
\hline Unit 1 , level 1 & & 0 & 0 & 0 & 0 & 0 & 0 & 0 & 0 \\
\hline Unit 1, level 2 & $\begin{array}{l}172 \pm 29(\text { cotton seed) } \\
\text { and } 122 \pm 29 \text { (barley } \\
\text { seed) }\end{array}$ & 0 & 0 & 0 & 0 & 0 & 0 & 0 & 0 \\
\hline Unit 1, level 3 & $300 \pm 30$ & 0 & 0 & 0 & 0 & 0 & 0 & 0 & 0 \\
\hline Unit 2, level 1 & & 0 & 7 & 0 & 0 & 1 & 0 & 0 & 0 \\
\hline Unit 2, level 2 & & 2 & 3 & 0 & 0 & 0 & 1 & 0 & 0 \\
\hline Unit 2, level 3 & & 0 & 1 & 0 & 0 & 0 & 1 & 0 & 2 \\
\hline Unit C7, level 1 & & 0 & 0 & 0 & 0 & 0 & 0 & 0 & 0 \\
\hline Unit C7, level 2 & & 0 & 0 & 0 & 0 & 0 & 0 & 0 & 0 \\
\hline Unit C7, level 3 & & 3 & 0 & 1 & 0 & 0 & 0 & 0 & 0 \\
\hline Unit C8, level 1 & & 0 & 0 & 0 & 2 & 0 & 0 & 0 & 0 \\
\hline Unit C8, level 2 & & 2 & 0 & 0 & 0 & 0 & 0 & 0 & 0 \\
\hline Unit D8, level 1 & & 0 & 0 & 0 & 0 & 0 & 0 & 0 & 0 \\
\hline Unit D8, level 2 & & 0 & 0 & 0 & 1 & 0 & 0 & 2 & 0 \\
\hline Unit D8, level 3 & & 0 & 0 & 0 & 2 & 0 & 0 & 0 & 0 \\
\hline Unit J5, level 1 & & 1 & 0 & 0 & 1 & 0 & 0 & 0 & 0 \\
\hline Unit J5, level 2 & & 0 & 0 & 0 & 0 & 0 & 0 & 0 & 0 \\
\hline Unit J5, level 3 & & 0 & 0 & 0 & 0 & 0 & 0 & 0 & 0 \\
\hline Unit M3, level 1 & & 0 & 0 & 0 & 0 & 0 & 0 & 0 & 0 \\
\hline Unit M3, level 2 & & 0 & 0 & 0 & 0 & 0 & 0 & 0 & 0 \\
\hline Unit M3, level 3 & & 0 & 0 & 0 & 0 & 0 & 0 & 0 & 0 \\
\hline Unit N2, level 1 & & 0 & 0 & 0 & 0 & 0 & 0 & 0 & 0 \\
\hline Unit N2, level 2 & & 0 & 0 & 0 & 0 & 0 & 0 & 0 & 0 \\
\hline Unit N2, level 3 & & 0 & 0 & 0 & 0 & 0 & 0 & 0 & 0 \\
\hline Unit N3, level 1 & & 2 & 0 & 1 & 0 & 0 & 0 & 0 & 0 \\
\hline Unit N3, level 2 & & 0 & 0 & 0 & 0 & 0 & 0 & 0 & 0 \\
\hline Unit N3, level 3 & & 0 & 0 & 0 & 0 & 0 & 0 & 0 & 0 \\
\hline Unit O2, level 1 & & 0 & 0 & 0 & 0 & 0 & 0 & 0 & 0 \\
\hline Unit O2, level 2 & & 0 & 0 & 0 & 0 & 0 & 0 & 0 & 0 \\
\hline Unit O2, level 3 & & 0 & 0 & 0 & 0 & 0 & 0 & 0 & 0 \\
\hline Unit O3, level 1 & & 0 & 0 & 0 & 0 & 1 & 0 & 0 & 0 \\
\hline Unit O3, level 2 & & 0 & 0 & 0 & 0 & 2 & 0 & 0 & 0 \\
\hline Unit O3, level 3 & & 0 & 0 & 0 & 0 & 0 & 0 & 0 & 0 \\
\hline Total & & 10 & 11 & 2 & 6 & 4 & 2 & 2 & 2 \\
\hline
\end{tabular}

are rare and appear on two sherds from Tuwatey, but none from Mota. The ceramic forms at Tuwatey are limited to jars, while the Mota ceramic assemblage consists of jars, bowls, and plates (Table 19). Furthermore, the use-alteration analysis of the pottery and the faunal analysis suggest that Mota Cave inhabitants had culinary practices that differed from those inhabiting Tuwatey Cave (Table 18). Usealteration analysis is beginning to be more widely utilized in African archaeology (e.g., Arthur 2002, 2003, 2014; Dunne et al. 2012, 2018; Reid and Young 2000). Ethnoarchaeological studies of ceramic use have confirmed specific use-alteration patterns, such as carbon deposits and surface abrasions 
Table 32 Recovered plant remains from Tuwatey Cave (GB15)

\begin{tabular}{|c|c|c|c|c|c|c|c|c|c|c|c|c|}
\hline & \multirow{2}{*}{$\begin{array}{l}\text { Gamo GB20 } \\
\text { Taxa }\end{array}$} & \multirow{2}{*}{$\begin{array}{l}\text { Unit } \\
\text { Level } \\
\text { Sample (SS) } \\
\text { Plant part }\end{array}$} & \multirow{2}{*}{$\begin{array}{l}\text { C7 } \\
4 \\
136\end{array}$} & \multirow{2}{*}{$\begin{array}{l}\mathrm{C} 7 \\
5 \\
138\end{array}$} & \multirow{2}{*}{$\begin{array}{l}\text { C7 } \\
6 \\
139\end{array}$} & \multirow{2}{*}{$\begin{array}{l}\mathrm{C} 7 \\
7 \\
141\end{array}$} & \multirow{2}{*}{$\begin{array}{l}\text { D8 } \\
3 \\
99\end{array}$} & \multicolumn{2}{|c|}{ TP1 (2011) } & \multirow[b]{2}{*}{$\begin{array}{l}\# 1-2 \mathrm{~L} \\
\# 5\end{array}$} & \multirow[b]{2}{*}{ \#1-3 } & \multirow[b]{2}{*}{$\begin{array}{l}\# 5 / 6 \\
\text { Bag \#8 }\end{array}$} \\
\hline & & & & & & & & $\# 7 / 8$ & $\# 1 / 2$ & & & \\
\hline \multirow[t]{4}{*}{ Barley } & Hordeum sp. & Grains & 2 & 3 & 2 & 4 & & & & 2 & & \\
\hline & Hordeum sp. apical end & Apical ends & & 2 & & & & & & & & \\
\hline & Hordeum sp. & Embryo ends & & & & & & & 1 & & & \\
\hline & cf. Hordeum sp. & Grain fragment & & & & & 1 & & & 1 & & \\
\hline Wheat & cf. Triticum & Grain fragment & & & & & & & & 1 & & \\
\hline \multirow[t]{2}{*}{ Sorghum } & Sorghum sp. & Grain & & & & & & & & 1 & & \\
\hline & cf. Sorghum sp. & Grain & & & & & & & & 1 & & \\
\hline Finger millet & Eleusine coracana & Grain & & & & & & & & 1 & 1 & \\
\hline \multirow[t]{2}{*}{ Cotton } & Gossypium sp. & Whole seed & & & & & & & & 1 & & \\
\hline & Gossypium sp. & Seed fragment & & & & & & & & 7 & & \\
\hline \multirow[t]{4}{*}{ Other } & cf. Rhamnus sp. & Seed fragment & & & & & & & & 1 & & \\
\hline & Cereal indeterminate & Fragments & & $\mathrm{x}$ & & 3 & 2 & & & 5 & & \\
\hline & Parenchyma tissue/tuber & Fragments & & & & & & $\mathrm{x}$ & & & & $\mathrm{x}$ \\
\hline & Total identifiable remains & & 2 & 5 & 2 & 7 & 3 & 0 & 1 & 21 & 1 & \\
\hline
\end{tabular}

on ceramic vessels that represent specific types of food processing (e.g., Arthur 2014; Skibo 1992, 2013). The lack of sooting on the sherds at Mota and high frequency of burn marks on fauna remains suggest that roasting rather than boiling may have been a more common cooking practice. This contrasts with Tuwatey where sooting was common, possibly from a wet mode of cooking, such as soups.

The evidence from Tuwatey Cave indicates the adoption of barley into the local economy by $500 \mathrm{BP}$, providing the earliest directly dated archaeological evidence for domestication of barley (Hordeum vulgare) in southern Ethiopia. The cotton seeds, dating to ca. AD 1700, are at present the earliest dated in southwestern Ethiopia, suggesting that the Boreda Gamo communities have been engaged in the weaving craft for at least the last two or three centuries. Subsequently, an expanded agricultural repertoire is evident from ca. $300 \mathrm{BP}$ that included wheat, sorghum, finger millet, and cotton.

\section{Regional Comparison}

The Gamo caves were occupied during three contemporary time periods, which provide evidence for changes in the lithic and food way assemblages through time: a Pre-Pottery period 5500-3200 BP, an Early Pottery period 2400-1600 BP, and a Historic period 500120 BP. Broadly, the microlithic tool technology recovered at Mota, Tuwatey, and Gulo with a later introduction of pottery and domesticates is characteristic of the Later Stone Age (LSA) between the Later Pleistocene Marine Isotope Stage 3 (MIS 3) and the Late Holocene

Table 33 AMS radiocarbon dates on seeds from Tuwatey

\begin{tabular}{lllllll}
\hline Context & Dated material & Lab no. & C14 age & Error & $\delta^{13} \mathrm{C}(\% \circ)$ & Calibrated (68.2\%) \\
\hline GB15-C7-7 & Hordeum vulgare & SUERC-61527 & 492 & 29 & -23.6 & $1416-1440$ AD \\
GB15-1-2L & Gossypium sp. & SUERC-61528 & 172 & 29 & -22.3 & $1668-1683,1734-1782,1798-1806,1929-1949$ AD \\
GB15-1-2L & Hordeum vulgare & SUERC-61529 & 122 & 29 & -21.5 & $1685-1708,1718-1732,1808-1888,1911-1928$ AD \\
\hline
\end{tabular}


Table 34 Faunal descriptions from Tuwatey during the Historic period

\begin{tabular}{lllllll}
\hline Tuwatey Cave GB 15 & Unit & Unit & Unit & Unit & Unit & M3 \\
unit & 1 & 2 & 2 & 2 & 2 & \\
\hline Level & 2 & 2 & 3 & 5 & 8 & 3 \\
Large bovid & 1 & 1 & 1 & 1 & 1 & \\
Suid & & 1 & & & & \\
Rodent & & & & & & 2 \\
Crab & & 1 & & & & 9 \\
\hline
\end{tabular}

(ca. 60,000 to $<1,000$ years BP). This is typified, in large part, by high frequencies of geometric microliths and small blade production with pottery production as early as $8000 \mathrm{BP}$, and the introduction of food production ca. 4000 BP (for reviews, see Ambrose 1998, 2002; Barham and Mitchell 2008; Bon and Fauvelle-Aymar 2014; Brandt 1986; Clark 1954; Clark and Williams
1978; Finneran 2007; Leplongeon 2014; Lesur et al. 2014a; Marshall and Hildebrand 2002; Phillipson 1982; for ceramics, see Bower and Nelson 1978; Prendergast and Lane 2008; Robbins 1972). LSA rockshelter and cave sites dating to the Holocene in Ethiopia are restricted to fewer than two dozen site areas, some with pottery as early as $3500 \mathrm{BP}$, but most of them are located outside southern Ethiopia (Assefa et al. 2014; Brandt 1980, 1986; Clark 1954; Clark and Williams 1978; Clark and Williamson 1984; Dombrowski 1970; Fernandez et al. 2007; Finneran 2000a, b, 2007; Guérin and Faure 1996; Gutherz et al. 1996, 2015; Jones et al. 2017; Leplongeon 2014; Lesur et al. 2014a; Ménard et al. 2014; Negash 1997, 2001; Phillipson 1977; Pleurdeau et al. 2014; Tribolo et al. 2017). The earliest evidence for pastoralism from northern Ethiopia dates to ca. 17411540 BCE (Marshall and Negash 2002; Lesur et al. 2014a), and West Asian cereals and indigenous grains appeared in the third millennium BP (Curtis 2013;

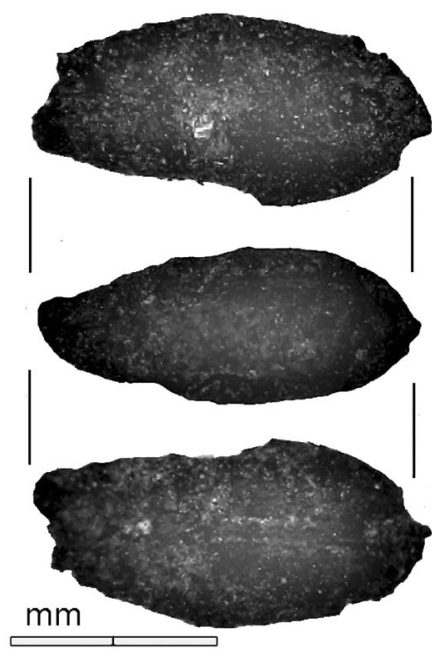

a

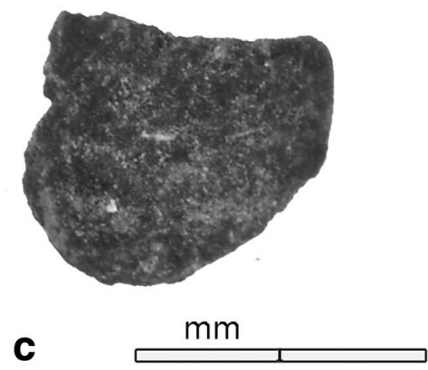

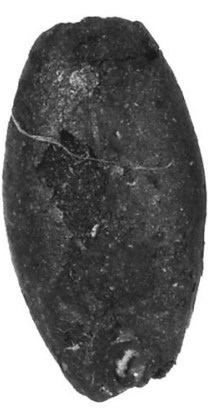

b
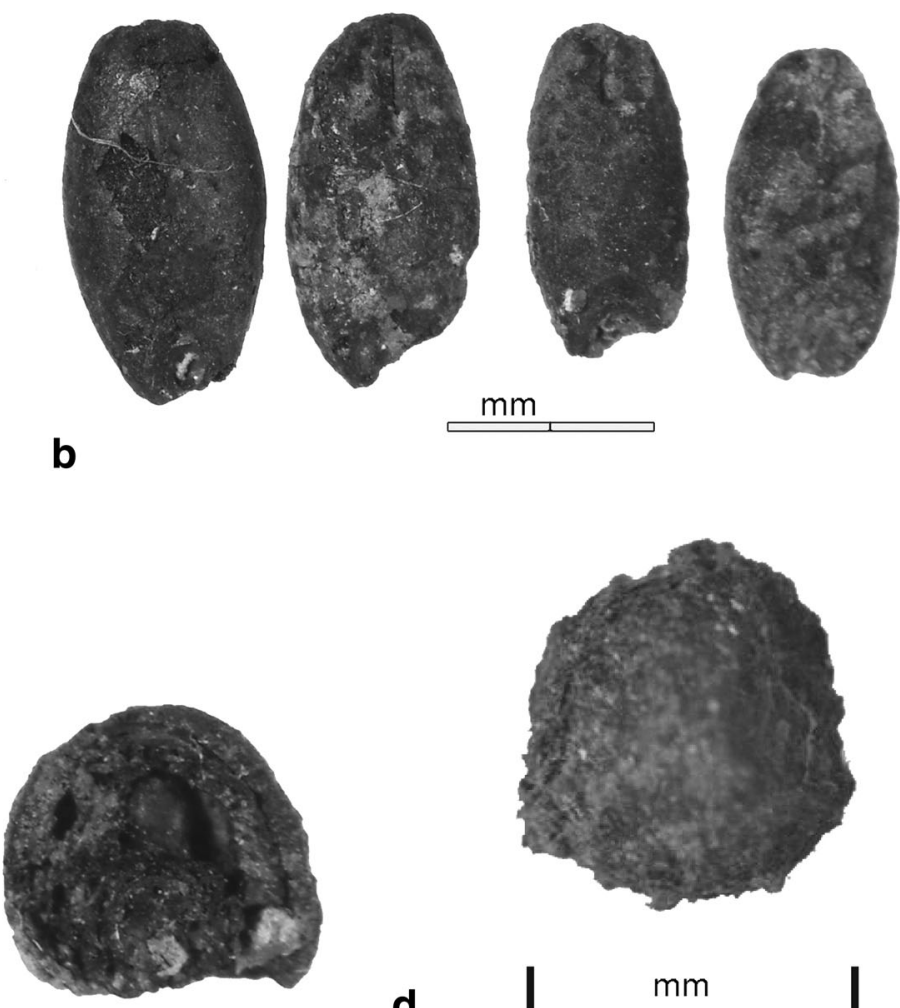

d

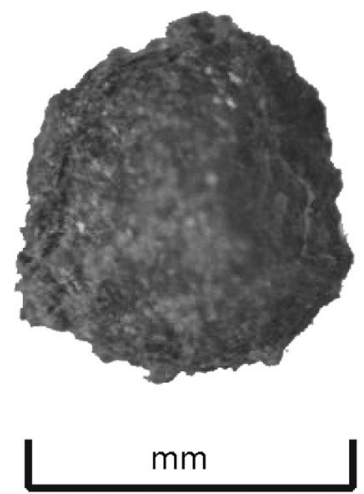

Fig. 24 a Barley grain from Mota Cave, dorsal, lateral, and ventral views. b Barley grains (dorsal view) from Tuwatey (C7-7). c Finger millet grain from Tuwatey (TP1-2L). d Cotton seeds from Tuwatey (TP1-2L) 
Table 35 Tuwatey Cave groundstone descriptions

\begin{tabular}{lllllll}
\hline Location & Type & Shape & Length $(\mathrm{mm})$ & Width $(\mathrm{mm})$ & Thickness $(\mathrm{mm})$ & Weight $(\mathrm{g})$ \\
\hline Unit O3 level 2 & Handstone & Oval & 88.6 & 50.9 & 45.4 & $>200$ \\
Unit M3 unit 2 & Handstone & Oval & 93.4 & 59.3 & 36.7 & $>200$ \\
\hline
\end{tabular}

D'Andrea et al. 2008b). The earliest evidence for herding and ceramic production in the Horn began by $2000 \mathrm{BP}$ and vegeculture sometime after $1740 \mathrm{BP}$ (Hildebrand et al. 2010; Lesur et al. 2014).

In southwestern Ethiopia, there are few Later Stone Age cave assemblages for comparison. Microlithic industries are variously defined as small blades and flakes under $30 \mathrm{~mm}$ in length and are generally associated with the LSA (Clark 1985, p. 95; Clark and Kleindienst 1974, p. 99), though microliths also are known in terminal Pleistocene assemblages (Brandt 1982; Brandt et al. 2012; Gutherz et al. 2014; Leplongeon 2014; Ménard et al. 2014). Clearly, resembling the other LSA cave and shelter site assemblages in southwestern Ethiopia, the people at the Gamo highland caves primarily produced small or microlithic retouched blades and flakes, backed flakes and blades, crescents, trapezoids, and triangleshaped geometrics, as well as awls, scrapers, and points. The lack of interest in studying Mid and Late Holocene sites in comparison to the Pleistocene-Holocene transitions means that studies are near nonexistent or assemblages are sparsely described. Fifty kilometers to the north of the Gamo Highlands are the sites of Harurona

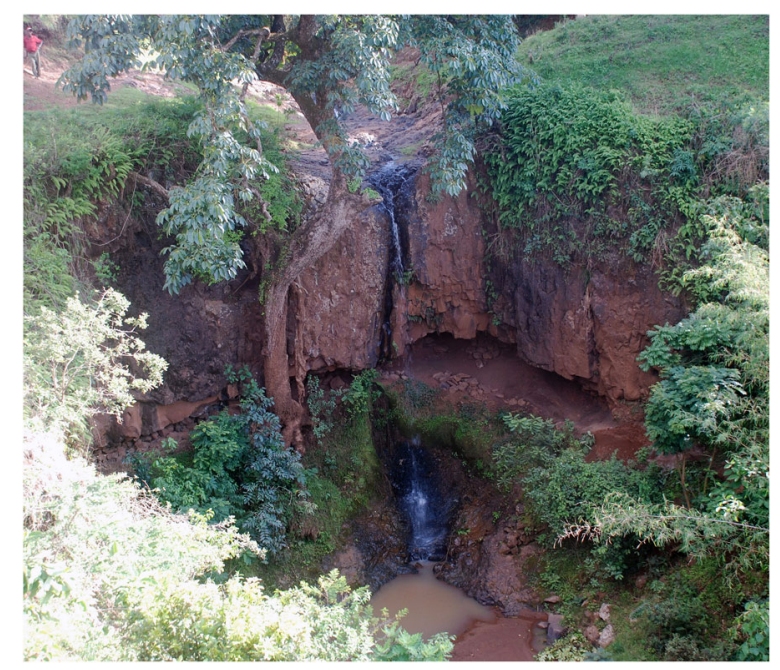

Fig. 25 Gulo Cave (ca. 12,000 BP to present) and Mochena Borago (ca. 4500-100 BP) in the Wolayta region (Bachechi 2005; Brandt et al. 2012; Gutherz et al. 2002) (Fig. 28). At Harurona, the assemblage from the terminal Pleistocene to Holocene is described as part of the Ethiopian Blade Tool Tradition associated with Lake Besaka to the north (Brandt 1980, 1982). Gutherz et al. (2002) mention that at Mochena Borago (ca. 45,000-100 BP), there are segments/crescents in the Mid-Holocene and blades in the Late Holocene but the proportions are unclear. Sixty kilometers to the southeast of the Gamo are the Rift Valley Mome Gongolo sites dating to ca. 1499-293 BP, demonstrating the continued production and use of quartz and obsidian tools particularly microliths, with the addition of chert, chalcedony, and rhyolite in the later occupation (Lesur et al. 2014b). More than $180 \mathrm{~km}$ to the south at Yabello, excavated assemblages at rockshelters have limited direct dating, ca. 29001300 BP (Clark 1945; Hundie 2001). About $200 \mathrm{~km}$ to the northwest of the Boreda Gamo Highlands, the Kafa region shelter sites of Kumali, Duba, Shelui, Koka, Shapa, and Chiri date between ca. 8400 and 130 BP. Here, there was a persistence of microliths primarily made of obsidian with scrapers produced from basalt and chert (Hildebrand and Brandt 2010; Hildebrand et al. 2010). Like the Gamo cave sites, a recent comparison of geometrics by Leplongeon and Ménard (2017) from Goda Buticha, Bulbula River sites, and Mochena Borago indicates that there is increased symmetry in tool forms in the Late Holocene (4.2 ka-present) compared to earlier periods.

Based on the current evidence from the Gamo Highlands, it appears that adoption of domesticated crops was a slow and intermittent process over a long period of time with local wild resources dominating food assemblages until circa the last 500 years. Pottery appeared ca. $2400 \mathrm{BP}$, slightly earlier than in the Kafa region. Wild animal remains dominate the assemblages of the Pre-Pottery and Early Pottery periods indicating that although domesticates appear ca. $1700 \mathrm{BP}$, they were either infrequently culled, herded 


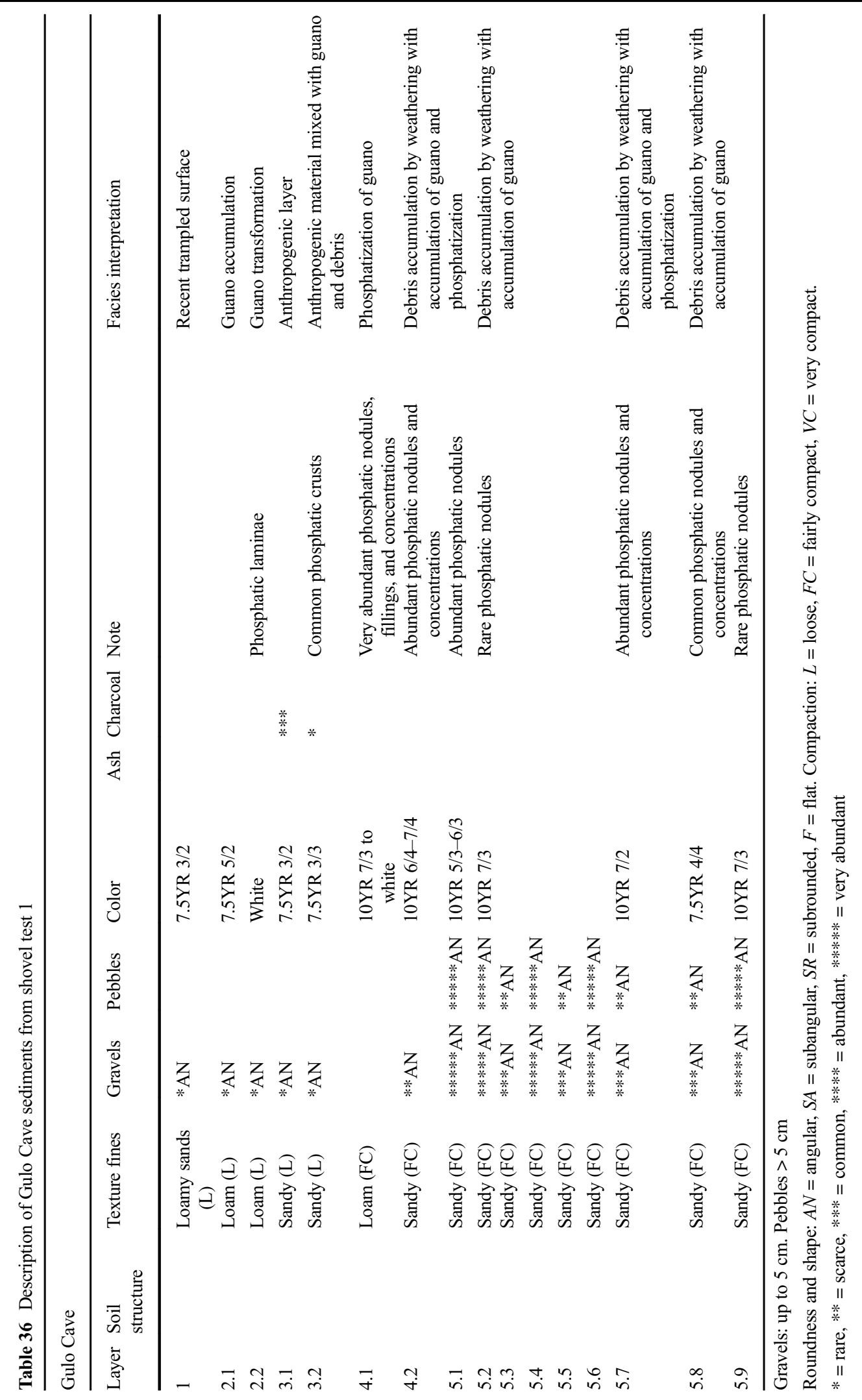


Fig. 26 Gulo Cave profile of shovel test 1

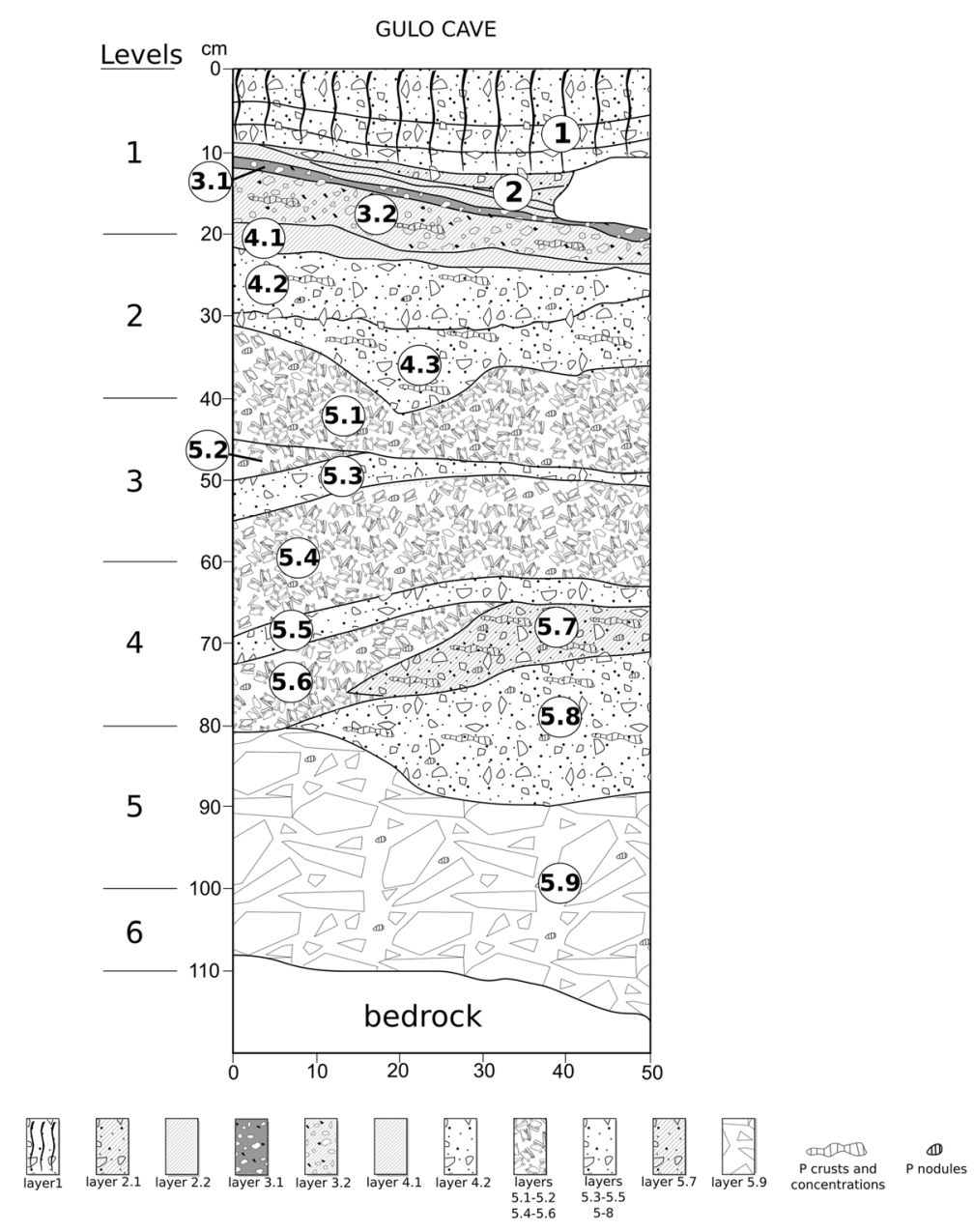

elsewhere, or acquired through trade, slightly later than documented in the Kafa region. The current archaeological research focusing on the development of food production is just beginning to concentrate on the Holocene record in southwestern Ethiopia (Hildebrand and Brandt 2010; Lesur et al. 2007, 2014b; K. Arthur et al. 2009,
2010). However, historic highland southwestern Ethiopia possessed food-producing traditions that include pastoralism, agropastoralism, horticulture, and more intensive forms of agriculture. Perhaps, most characteristic of southwestern Ethiopia are the horticultural traditions focusing on the propagated tuber crops of enset and yams.
Fig. 27 A comparison of the breadth/length and thickness/ length ratio of the geometric tools at Mota Cave indicating increased standardization through time

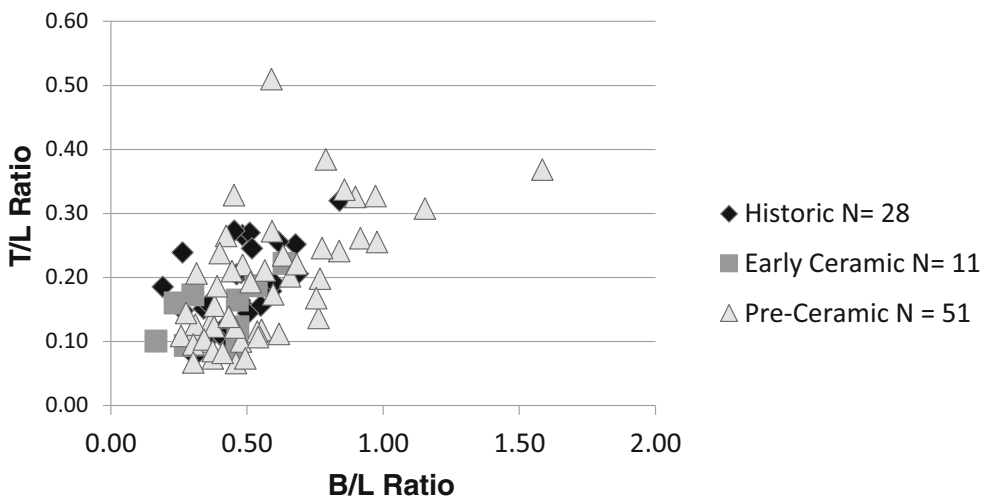


Fig. 28 Site and region locations discussed in the text in relation to early lithics, ceramics, and/or food production

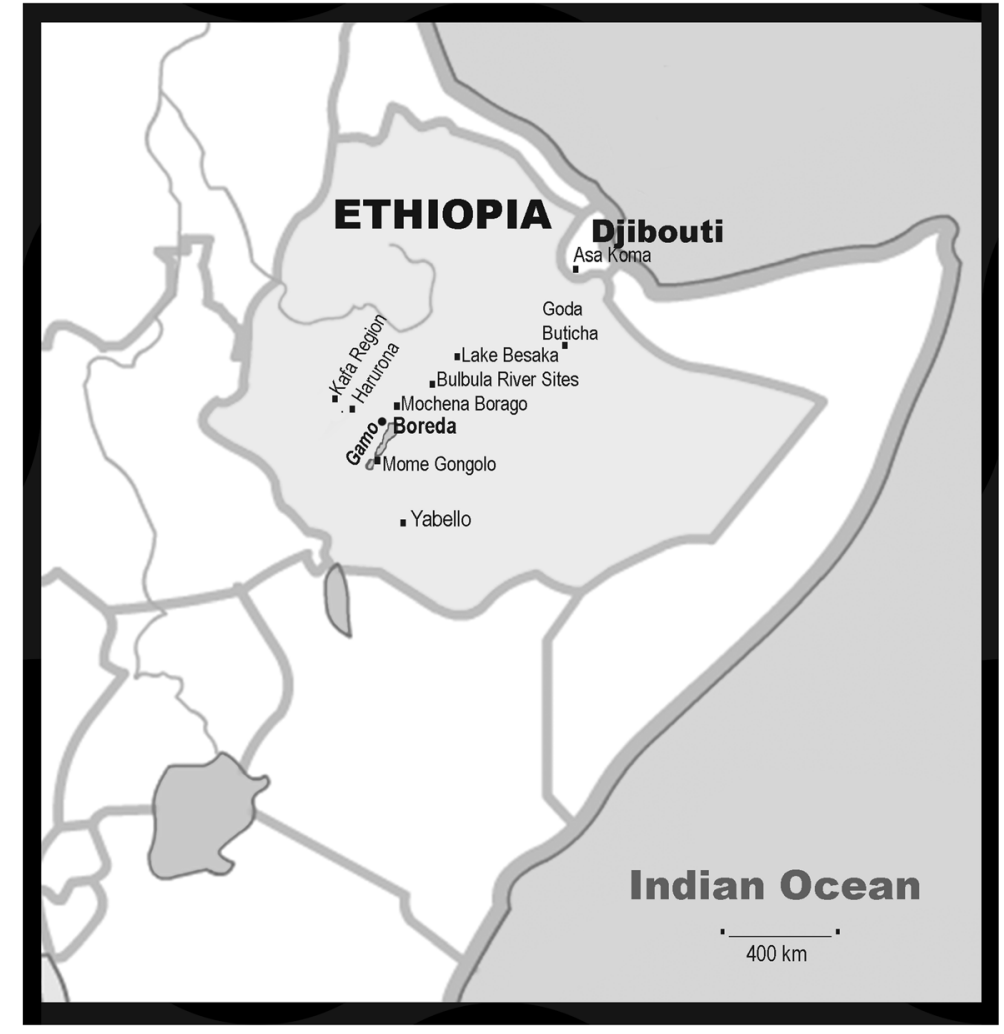

The understanding of when, how, or why this complex suite of adaptations developed still remains elusive. All of these point to the need for further work in the Gamo Highlands and other environmental zones of southwestern Ethiopia.

\section{Conclusion}

Why do domesticated flora and fauna appear so late in the archaeological record of southwestern Ethiopia compared to adjacent regions, such as in northern Kenya (third millennium BP) (Marshall 2000) and other sites in the Horn of Africa including Asa Koma (Lesur 2004), Laga Oda (Clark and Prince 1978; Clark and Williams 1978), and Lake Besaka (Brandt 1980, 1984)? Different reasons may explain this situation. On one hand, paleoenvironmental data show that the strong climatic variations characterizing the Holocene were less pronounced in southwestern Ethiopia where altitude and the well-developed hydrological networks limited the effects of aridity (Mohammed and Bonnefille 1998). A reduction in rainfall might have created drier ecosystems during some phases, but was never sufficiently drastic to completely modify natural formations. Therefore, most communities in the southern highlands continued to rely mainly on wild resources, as is the case at Mochena Borago (Lesur et al. 2007). Unlike the lowlands where the deterioration of climatic and environmental conditions forced populations to find alternative solutions, such as greater mobility or the adoption of domestic resources, the communities in the mountains benefitted from a stable natural environment that ensured continuity in food-sourcing strategies.

In other words, the region's rich landscapes and abundant wild resources may not have been propitious to early food producers. Climatic conditions with heavy rains and cold temperatures, as well as wet and dense forests, create a difficult environment for agriculture and livestock farming, for migratory producers, as well as for permanent local settlers who wished to keep small herds of cattle or cultivate cereals. Similarly, the steep and rugged topography of this mountainous zone could have acted as a physical barrier for pastoralists coming from the plains and could have slowed down the diffusion of cattle and caprines (Lesur et al. 2014a). Lastly, it is also important to address the difficulty of integrating the production of plants and domestic animals in the 
social and economic hunter-gatherer system (Brooks et al. 1984; Guille-Escuret 1989; Marshall et al. 2004), particularly in specialized societies well adapted to their specific environment, as has already been observed in comparable contexts linked to insularity (Vigne 1997). One clue to this resistance to adoption of food production may be observed in the unique vocabulary of Omotic speakers, such as the Gamo, have for domesticated animals (Blench 2006; Blench and MacDonald 2006). In her ethnographic research with the Gamo, K. Arthur (2018, p. 35) noted that Gamo words for cattle and goat are similar to those used for parallel wild species, especially African buffalo and dik-dik, that were important in historic ritual hunts and in the earlier hunting traditions of the region.

Our research has spurred additional questions focusing on intersite diversity and regional interactions. For example, are there other burials in the Gamo Highlands that could add to our knowledge of highland population adaptation, diet, and ritual practices? Distinctions in features and artifact and ecofact assemblages between Mota and Tuwatey caves suggest important variation in the quality and intensity of occupations. How might future research at the much less investigated Gulo Cave and other untested sites in the area compare and contrast with these better-explored sites? What might future obsidian sourcing studies provide for investigating ancient interaction spheres in southern Ethiopia that may have linked the Gamo Highlands to wider regional networks during the Middle and Late Holocene? Future research by our project and others suggests that southern Ethiopia may provide exciting insights into this critically important period of the Eastern African past.

\footnotetext{
Acknowledgments We are extremely grateful for the continued support that the communities of the Gamo Highlands have given to this research. We would like to thank the National Science Foundation (BCS-1027607), the National Endowment for the Humanities, the University of South Florida St. Petersburg (USFSP), and the University of South Florida Tampa for supporting this research. We especially would like to thank Yohannes Ethiopia Tocha and Gezahegn Alemayehu, who helped facilitate our research. This project has been successful because of the dedication to professionalism by the Ethiopian administration and we thank Jara Hailemariam and Yonas Desta, Director Generals of Authority for Research and Conservation of the Cultural Heritage (ARCCH). Ato Bizauyehu Lakew from the ARCCH Hawassa office facilitated our research with upmost respect, care, and diligence and we are forever grateful for his service to the project. We are grateful for the support of Wz. Mamito, Head of the National Museum of Ethiopia; Getachew Senishaw, Cultural Heritage Collection and Lab Service Directorate Director; Dr.
}

Yonas Bayene and Desalegn Abebaw Andualem, Cultural Heritage Research Directorate Directors; Daweat Tibebu Desta, Archaeology Research Case Team; Woinshet Tefera, Assistant Office Manager of the Cultural Heritage Collection and Lab Service; Kebede Gelota, Archaeology Senior Curator; Getu Alemayehu, Historical Archaeology Curator; Yared Assefa, Paleoanthropology Junior Curator; Menkir Bitew Tesemma, Intangible Cultural Heritage Research Case Team; and Tadesse Almaw, Heritage Documentation Officer. Archaeobotanical analyses and direct radiocarbon dating of seeds was supported by the "Comparative Pathways to Agriculture" project, a grant from the European Research Council (no. 323842) awarded to Dorian Fuller. We thank the former USFSP undergraduates, Abigail Tirabassi, Elizabeth Southard Razzouk, and Kendal Jackson, who helped excavate and process the lab material from the caves. We also appreciate Tilahun Chanche for his assistance during excavations. We appreciate and thank the two anonymous reviewers who provided suggestions to improve the article. Lastly, we thank our family members for being patient with us as we explore the highlands of southwestern Ethiopia.

\section{Compliance with Ethical Standards}

Conflict of Interest The authors declare that they have no conflict of interest.

Open Access This article is distributed under the terms of the Creative Commons Attribution 4.0 International License (http:// creativecommons.org/licenses/by/4.0/), which permits use, duplication, adaptation, distribution and reproduction in any medium or format, as long as you give appropriate credit to the original author(s) and the source, provide a link to the Creative Commons license and indicate if changes were made.

Publisher's Note Springer Nature remains neutral with regard to jurisdictional claims in published maps and institutional affiliations.

\section{References}

Ambrose, S. H. (1998). Chronology of the Later Stone Age and food production in East Africa. Journal of Archaeological Science, 25(4), 377-392.

Ambrose, S. H. (2002). Small things remembered: Origins of early microlithic industries in sub-Saharan Africa. In R. G. Elston \& St. L. Kuhn (Eds.), Thinking small: Global perspectives on microlithization (pp. 9-29). Archeological papers of the American Anthropological Association number 12.

Arthur, J. W. (2002). Pottery use-alteration as an indicator of socioeconomic status: An ethnoarchaeological study of the Gamo of Ethiopia. Journal of Archaeological Method and Theory, 9(4), 331-355.

Arthur, J. W. (2003). Brewing beer: Status, wealth, and ceramic use-alteration among the Gamo of southwestern Ethiopia. World Archaeology, 34(3), 516-528. 
Arthur, J. W. (2006). Living with pottery: Ethnoarchaeology among the Gamo of southwestern Ethiopia. Foundations of archaeological inquiry. Salt Lake City: University of Utah Press.

Arthur, J. W. (2014). Culinary crafts and foods in southwestern Ethiopia: An ethnoarchaeological study of Gamo groundstones and pottery. African Archaeological Review, 31(2), 131-168.

Arthur, K. W. (2010). Feminine knowledge and skill reconsidered: Women and flaked stone tools. American Anthropologist, 112(2), 228-243.

Arthur, K. W. (2018). The lives of stone tools: Crafting the status, skill, and identity of flintkappers. Tucson: The University of Arizona Press.

Arthur, K. W., Arthur, J. W., Curtis, M. C., Lakew, B., LesurGebremarium, J., \& Ethiopia, Y. (2009). Historical archaeology in the highlands of southern Ethiopia: Preliminary findings. Nyame Akuma, 72, 3-11.

Arthur, K. W., Arthur, J. W., Curtis, M. C., Lakew, B., LesurGebremarium, J., \& Ethiopia, Y. (2010). Fire on the mountain: Dignity and prestige in the history and archaeology of the Borada Highlands in southern Ethiopia. The SAA Archaeological Record, 10(1), 17-21.

Arthur, K. W., Tocha, Y. E., Curtis, M. C., Lakew, B., \& Arthur, J. W. (2017). Seniority through ancestral landscapes: Community archaeology in the highlands of southern Ethiopia. Journal of Community Archaeology and Heritage, 4(2), 101-114.

Ashley, G. M., Ndiema, E. K., Spencer, J. Q. G., Harris, J. W. K., \& Kiura, P. W. (2011). Paleoenvironmental context of archaeological sites, implications for subsistence strategies under Holocene climate change, northern Kenya. Geoarchaeology, 26(6), 809-837.

Asmare, M. T. (2015). Reconstructing food systems from the Late Holocene context of Mochena Borago rock shelter, Wolayta, southern Ethiopia. Unpublished Master's thesis, Addis Ababa: Addis Ababa University.

Assefa, Z., Pleurdeau, D., Duquesnoy, F., Hovers, E., Pearson, O., Asrat, A., T/Tsion, C., \& Lam, Y. M. (2014). Survey and explorations of caves in southeastern Ethiopia: Middle Stone Age and Later Stone Age archaeology and Holocene rock art. Quaternary International, 343, 136-147.

Bachechi, L. (2005). Preliminary report on the 2002 excavation of the Haruona Cave deposit. In C. Cavanna (Ed.), Wolayta: Una regione D'Etiopia sudi e ricerche 1995-2004 (pp. 6778). Atti Del Museo Di Soria Naturale Della Maremma Supplemento al N. 21.

Bard, K. A., Fattovich, R., Manzo, A., \& Perlingieri, C. (1997). Archaeological investigations at Bieta Giyorgis (Aksum), Ethiopia: 1993-1995 field seasons. Journal of Field Archaeology, 24(4), 387-403.

Barham, L. (2013). From hand to handle: The first industrial revolution. Oxford: Oxford University Press.

Barham, L., \& Mitchell, P. (2008). The first Africans: African archaeology from the earliest toolmakers to most recent foragers (the Cambridge world prehistory). New York: Cambridge University Press.

Barnett, T. (1999). Quiha rock shelter, Ethiopia: Implications for domestication. Azania: Journal of the British Institute in Eastern Africa, 34(1), 11-24.

Barthelme, J. W. (1984). Early evidence for animal domestication in eastern Africa. In J. D. Clark \& S. A. Brandt (Eds.), From hunters to farmers: The causes and consequences of food production in Africa (pp. 200-203). Berkeley: University of California Press.

Beldados, A., D’Andrea, A. C., \& Manzo, A. (2015). Filling the gap: New archaeobotanical evidence for $3^{\text {rd }}-1^{\text {st }}$ millennium $\mathrm{BC}$ agricultural economy in Sudan and Ethiopia. In A. Florenzano \& R. Fornaciari (Eds.), $8^{\text {th }}$ International workshop for African archaeobotany (pp. 151-154). Modena, Italy: Societàdei Naturalistie Matematici di Modena and Società Botanica Italiana.

Bender, M. L. (1988). Proto-Omotic phonology and lexicon. In M. Bechhaus-Gerst, F. Serzisko (Eds.), Cushitic-Omotic. Papers from the international symposium on Cushitic and Omotic languages, Cologne Jan. 6-9 (pp. 121-162). Helmut Buske.

Blench, R. (2006). Archaeology, language, and the African past. Lanham: AltaMira Press.

Blench, R. M., \& Dendo, M. (2008). Omotic livestock terminology and its implications for the history of Afroasiatic. In G. Takacs (Ed.), Semito-Hamitic festschrift for AB Dolgopolsky and H. Jungraithmayr (pp. 63-78). Berlin: Dietrich Reimer Verlag.

Blench, R., \& MacDonald, K. (Eds.). (2006). The origins and development of African livestock: Archaeology, genetics, linguistics and ethnography. New York: Routledge.

Boardman, S. (1999). The agricultural foundation of the Aksumite Empire, Ethiopia. In M. van der Veen (Ed.), The exploitation of plant resources in ancient Africa (pp. 137-147). New York: Springer.

Bon, F., \& Fauvelle-Aymar, F. X. (2014). Prehistory of East Africa (the Cambridge world prehistory). New York: Cambridge University Press.

Bower, J., \& Nelson, C. M. (1978). Early pottery and pastoral cultures of the central Rift Valley, Kenya. Man, 13(4), 554-566.

Brandt, S. A. (1980). Archaeological investigations at Lake Besaka, Ethiopia. In R. E. F. Leakey \& B. A. Ogot (Eds.), Proceedings of the eighth Panafrican congress of prehistory and quaternary studies (pp. 239-243). Nairobi: The International Louis Leakey Memorial Institute of African Prehistory.

Brandt, S. A. (1982). A Late Quaternary cultural environmental sequence for Lake Besaka, Southern Afar, Ethiopia $(\mathrm{PhD}$ thesis, UMI). Berkeley: University of California.

Brandt, S. A. (1984). New perspectives on the origins of food production in Ethiopia. In J. D. Clark \& S. A. Brandt (Eds.), From hunters to farmers: The causes and consequences of food production in Africa (pp. 173-190). Berkeley: University of California Press.

Brandt, S. A. (1986). The Upper Pleistocene and early Holocene prehistory of the Horn of Africa. African Archaeological Review, 4(1), 41-82.

Brandt, S. A., \& Carder, N. (1987). Pastoral rock art in the Horn of Africa: Making sense of udder chaos. World Archaeology, 19(2), 194-213.

Brandt, S. A., Spring, A., Hiebsch, C., McCabe, J. T., Tabogie, E., Diro, M., Wolde-Michael, G., Yntiso, G., Shigeta, M., \& Tesfaye, S. (1997). The tree against hunger. Enset-based agricultural systems in Ethiopia. New York: American Association for the Advancement of Science.

Brandt, S. A., Fischer, E. C., Hildebrand, E. A., Vogelsang, R., Ambrose, S. H., Lesur, J., \& Wang, H. (2012). Early MIS 3 occupation of Mochena Borago rockshelter, southwestern Ethiopian Highlands: Implications for Late Pleistocene 
archaeology, paleoenvironments and modern human dispersals. Quaternary International, 274, 38-54.

Brooks, A., Gelburd, D. E., \& Yellen, J. (1984). Food production and culture change among the !Kung San: Implications for prehistoric research. In J. D. Clark \& S. A. Brandt (Eds.), From hunters to farmers: The cause and consequences of food production in Africa (pp. 293-310). Berkeley: University of California Press.

Buikstra, J. E., \& Ubelaker, D. (1994). Standards for data collection from human skeletal remains. Arkansas archeological survey research series no 44. Fayetteville, Arkansas.

Clark, J. D. (1945). Short notes on Stone Age sites at Yavello, southern Abyssinia. Transactions of the Royal Society of South Africa, 31(1), 29-37.

Clark, J. D. (1954). The prehistoric cultures of the Horn of Africa. New York: Cambridge.

Clark, J. D. (1980). Human populations and cultural adaptations in the Sahara and Nile during prehistoric times. In M. A. J. Williams \& H. Faure (Eds.), The Nile and the Sahara (pp. 527-582). Rotterdam: A. A. Balkema.

Clark, J. D. (1985). The microlithic industries of Africa: Their antiquity and possible economic implications. In V.N. Misra and P.S. Bellwood (Eds.), Recent advances in Indo-Pacific prehistory: Proceedings of the international symposium held at Poona, December 19-21, 1978 (pp. 95-103). Leiden: E. J. Brill.

Clark, J. D. (1988). A review of the archaeological evidence for the origins of food production in Ethiopia. In T. Beyene (Ed.) Proceedings of the eighth international conference of Ethiopian studies, vol. 1, (pp. 55-69). Addis Ababa: Institute of Ethiopian Studies.

Clark, J. D., \& Kleindienst, M. R. (1974). The Stone Age cultural sequence: Terminology, typology, and raw material. In J. D. Clark (Ed.), Kalambo Falls prehistoric site: The later prehistoric cultures (Vol. II, pp. 71-106). Cambridge: Cambridge University Press.

Clark, J. D., \& Prince, G. R. (1978). Use-wear on Later Stone Age microliths from Laga Oda, Haraghi, Ethiopia and possible functional interpretations. Azania: Journal of the British Institute in Eastern Africa, 13(1), 101-110.

Clark, J. D., \& Williams, M. A. J. (1978). Recent archaeological research in southeastern Ethiopia. 1974-1975. Annales d'Ethiopie, 11(1), 19-44.

Clark, J. D., \& Williamson, K. D. (1984). A Middle Stone Age occupation site at Porc-Epic cave, Dire Dawa (east-central Ethiopia), part I. African Archaeological Review, 2(1), 3764.

Conyers, L. B. (2013). Ground-penetrating radar for archaeology (3rd ed.). Lanham: Alta Mira Press.

Conyers, L. B. (2016). Ground-penetrating radar for geoarchaeology. London: Wiley-Blackwell.

Curtis, M. C. (2004). Ancient interaction across the southern Red Sea: New suggestions for cultural exchange and complex societies during the first millennium BC. In P. Lunde \& A. Porter (Eds.), Trade and travel in the Red Sea region (pp. 5770). Oxford: Archaeopress.

Curtis, M. C. (2008). New perspectives for examining change and complexity in the Northern Horn of Africa during the first millennium BCE. In P. R. Schmidt, M. C. Curtis, \& Z. Teka (Eds.), The archaeology of ancient Eritrea (pp. 329-348). Trenton: Red Sea Press.
Curtis, M. C. (2009). Relating the ancient Ona culture to the wider northern Horn: Discerning patterns and problems in the archaeology of the first millennium BC. African Archaeological Review, 26(4), 327-350.

Curtis, M. C. (2013). Archaeological evidence for the emergence of food production in the Horn of Africa. In P. Mitchell \& P. Lane (Eds.), The Oxford handbook of African archaeology (pp. 571-584). Oxford: Oxford University Press.

D'Andrea, A. C. (2008). T'ef (Eragrostis tef) in ancient agricultural systems of highland Ethiopia. Economic Botany, 62(4), 547-566.

D’Andrea, A. C., Lyons, D., Haile, M., \& Butler, A. (1999). Ethnoarchaeological approaches to the study of prehistoric agriculture in the highlands of Ethiopia. In M. van der Veen (Ed.), The exploitation of plant resources in ancient Africa (pp. 101-122). New York: Springer Press.

D'Andrea, A. C., Schmidt, P. R., \& Curtis, M. C. (2008a). Paleoethnobotanical analysis and agricultural economy in early first millennium BCE sites around Asmara. In P. Schmidt, M. Curtis, \& Z. Teka (Eds.), The archaeology of ancient Eritrea (pp. 207-216). Trenton: The Red Sea Press.

D’Andrea, A. C., Manzo, A., Harrower, M. J., \& Hawkins, A. J. (2008b). The Pre-Aksumite and Aksumite settlement of NE Tigrai, Ethiopia. Journal of Field Archaeology, 33(2), 151-176.

D’Andrea, A. C., Richards, M. P., Pavlish, L. A., Wood, S., Manzo, A., \& Wolde-Kiros, H. S. (2011). Stable isotopic analysis of human and animal diets from two pre-Aksumite/ proto-Aksumite archaeological sites in northern Ethiopia. Journal of Archaeological Science, 38(2), 367-374.

Dombrowski, J. C. (1970). Preliminary report on excavations in Lalibela and Natcheibet Caves. Annales d'Ethiopie, 8, 21-29.

Dunne, J., Evershed, R. P., Salue, M., Cramp, L., Bruni, S., Ryan, K., Biagetti, S., \& di Lernia, S. (2012). First dairying in green Saharan Africa in the fifth millennium BC. Nature, 486(7403), 390-394.

Dunne, J., Grillo, K. M., Caanova, E., Whelton, H. L., \& Evershed, R. P. (2018). Pastoralist foodways recorded in organic residues from pottery vessels of modern communities in Samburu, Kenya. Journal of Archaeological Method and Theory, 1-24. https://doi.org/10.1007/s10816-018-9384-0.

Ehret, C. (2000). Language and history. In B. Heine \& D. Nurse (Eds.), African languages: An introduction (pp. 272-297). Cambridge: Cambridge University Press.

Fattovich, R. (2010). The development of ancient states in the Northern Horn of Africa, c. 3000 BC-AD 1000: An archaeological outline. Journal of World Prehistory, 23(3), 145-175.

Fattovich, R. (2012). The northern Horn of Africa in the first millennium BCE: Local traditions and external connections. Rassegna di Studi Etiopici, 4, 1-60.

Feldesman, M., \& Fountain, R. L. (1996). Race specificity and the femur/stature ratio. American Journal of Physical Anthropology, 100(2), 207-224.

Fernandez, F. M., de la Torre, I., Luque, L., González-Ruibal, A., \& López-Sáez, J. A. (2007). A Late Stone Age sequence from West Ethiopia: The sites of K'aaba and Bel K'urk'umu (Assosa, Benishangul-Gumuz Regional State). Journal of African Archaeology, 5(1), 91-126.

Finneran, N. (2000a). A new perspective on the Late Stone Age of the northern Ethiopian highlands: Excavations at Anqqer Baahti, Aksum, Ethiopia 1996. Azania, 35, 21-51. 
Finneran, N. (2000b). Excavations at the Late Stone Age site of Baahti Nebait, Aksum, northern Ethiopia, 1997. Azania, 35, 53-73.

Finneran, N. (2007). The archaeology of Ethiopia. New York: Routledge Press.

Fuller, D., \& Hildebrand, L. (2013). Domesticating plants in Africa. In P. Mitchell \& P. Lane (Eds.), Oxford handbook of African archaeology (pp. 507-525). Oxford: Oxford University Press.

Fuller, D. Q., Nixon, S., Stevens, C. J., \& Murray, M. (2014). African archaeobotany expanding. In C. Stevens, S. Nixon, M. Murray, \& D. Q. Fuller (Eds.), Archaeology of African plant use (pp. 17-24). Walnut Creek: Left Coast Press.

Gallego Llorente, M., Jones, E. R., Eriksson, A., Siska, V., Arthur, K. W., Arthur, J., Curtis, M. C., Stock, J. T., Coltorti, M., Pieruccini, P., Stretton, S., Brock, F., Higham, T., Park, Y., Hofreiter, M., Bradley, D. G., Bhak, J., Pinhasi, R., \& Manica, A. (2015). Ancient Ethiopian genome reveals extensive Eurasian admixture in eastern Africa. Science, $350(6262), 820-822$.

Guérin, C., \& Faure, M. (1996). Chasse au chacal et domestication dub Oeuf dans le Site néolithique d'Asa Koma (Républiqaue de Djibouti). Journal des Africanistes, 66, 299-311.

Guille-Escuret, G. (1989). Les sociétiés et leurs natures. Paris: Armand Colin.

Gutherz, X., Joussaume, R., Amblard, S., \& Mohammed, G. (1996). Le site d'Asa Koma (République de Djibouti) et les premiers producteurs dans la Corne de l'Afrique. Journal des Africanistes, 66, 255-297.

Gutherz, X., Jallot, L., Lesur, J., Pouzolles, G., \& Sordoillet, D. (2002). Les fouilles de l'abri sous-roche de Moche Borago (Soddo-Wolayta). Premier bilan. Annales d'Ethiopie, 18, 181-190.

Gutherz, X., Diaz, A., Ménard, C., Bon, F., Douze, K., Léa, V., Lesur, J., \& Sordoillet, D. (2014). The Hargesisan revisited: Lithic industries from shelter 7 of Laas Geel, Somaliland and the transition between the Middle and Late Stone Age in the Horn of Africa. Quaternary International, 343, 69-84.

Gutherz, X., Lesur, J., Cauliez, J., Charpentier, V., Diaz, A., Ismaël, M. O., Pène, J.-M., Sordoillet, D., \& Zazzo, A. (2015). New insights on the first Neolithic societies in the Horn of Africa: The site of Wakrita, Djibouti. Journal of Field Archaeology, 40(1), 55-68.

Harlan, J. R. (1969). Ethiopia: A center of diversity. Economic Botany, 23(4), 309-314.

Harlan, J. R. (1971). Agricultural origins: Centers and noncenters. Science, 174(4008), 468-474.

Harlan, J. R. (1992). Indigenous African agriculture. In C. Cowen \& P. J. Watson (Eds.), The origins of agriculture: An international perspective (pp. 59-70). Smithsonian: Washington, D.C..

Harrower, M. J., \& D'Andrea, A. C. (2014). Landscapes of state formation: Geospatial analysis of Aksumite settlement patterns (Ethiopia). African Archaeological Review, 31(3), 513-541.

Harrower, M. J., McCorriston, J., \& D'Andrea, C. A. (2010). General/specific, local/global: Comparing the beginnings of agriculture in the Horn of Africa (Ethiopia/Eritrea) and Southwest Arabia (Yemen). American Antiquity, 75(3), 452-472.

Hildebrand, E. A. (2007). A tale of two tuber crops: How attributes of enset and yams may have shaped prehistoric human-plant interactions in southwest Ethiopia. In T. Denham, L.
Vrydaghs, \& J. Iriarte (Eds.), Rethinking agriculture: Archaeological and ethnoarchaeological perspectives (pp. 273-298). Berkeley: Left Coast Press.

Hildebrand, E. A., \& Brandt, S. A. (2010). An archaeological survey of the tropical highlands of Kafa, southwestern Ethiopia. Journal of African Archaeology, 8(1), 43-63.

Hildebrand, E. A., \& Grillo, K. M. (2012). Early herders and monumental sites in eastern Africa: Dating and interpretation. Antiquity, 86(332), 338-352.

Hildebrand, E. A., Brandt, S. A., \& Lesur-Gebremariam, J. (2010). The Holocene of southwest Ethiopia: New insights from the Kafa archaeological project. African Archaeological Review, 27(4), 255-289.

Hundie, G. (2001). The emergence of prehistoric pastoralism in southern Ethiopia. Ph.D. dissertation, University of Florida, Gainesville, Florida.

Jones, M., Brandt, S. A., \& Marshall, F. (2017). Hunter-gatherer reliance on inselbergs, big game, and dwarf antelope at the Rifle Range Site, Buur Hakaba, southern Somalia 20,000 5,000 BP. Quaternary International, 471, 55-65.

Leplongeon, A. (2014). Microliths in the Middle and Later Stone Age of eastern Africa: New data from Porc-Epic and Goda Buticha cave sites, Ethiopia. Quaternary International, 343, 100-116.

Leplongeon, A. \& Ménard, C. (2017). Back pieces and their significance in the Later Stone Age of the Horn of Africa. Poster presentation number 16. European Society for the Study of Human Evolution ESHE, $7^{\text {th }}$ Annual Meeting Leiden, The Netherlands $21^{\text {st }}-23^{\text {rd }}$ Sept. 2017.

Lesur, J. (2004). Exploitation de la diversité faunique et début du pastoralisme dans la corne del'Afrique à l'Holocène. Première approche archéozoologique régionale. Unpublished Ph.D. thesis, Universite' de Paris I.

Lesur, J., Vigne, J.-D., \& Gutherz, X. (2007). Exploitation of wild mammals in South-west Ethiopia during the Holocene (4000 BC-500 AD): The finds from Moche Borago shelter (Wolayta). Environmental Archaeology, 12(2), 139-159.

Lesur, J., Hildebrand, E. A., Abawa, G., \& Gutherz, X. (2014a). The advent of herding in the Horn of Africa: New data from Ethiopia, Djibouti and Somaliland. Quaternary International, $343,148-158$.

Lesur, J., Gutherz, X., Jallot, L., Diaz, A., \& Arthur, J. (2014b). Late Holocene societies from southern Ethiopia: Results from archaeological project in Nechisar National Park. Annales d'Ethiopie, 29(2014), 265-268.

Manzo, A. (2009). Capra nubiana in Berbere sauce? Pre-Aksumite art and identity building. African Archaeological Review, 26(4), 291-303.

Marshall, F. (2000). The origins and spread of domestic animals in East Africa. In R. M. Blench \& K. C. MacDonald (Eds.), The origins and development of African livestock: Archaeology, genetics, linguistics, and ethnography (pp. 191-221). New York: Routledge.

Marshall, F., \& Hildebrand, E. (2002). Cattle before crops: The beginnings of food production in Africa. Journal of World Prehistory, 16(2), 99-143.

Marshall, F., \& Negash, A. (2002). Early hunters and herders of northern Ethiopia: The fauna from Danei Kawlos and Baati Ataro rockshelters. Paper presented at the Society of Africanist Archaeologists $16^{\text {th }}$ biennial conference, University of Arizona, May 18-21, Tucson. 
Marshall, F., \& Weissbrod, L. (2011). Domestication processes and morphological change. Current Anthropology, 52(S4), S397-S413.

Marshall, F., Stewart, K. S., \& Barthelme, J. (1984). Early domestic stock at Dongodien in northern Kenya. Azania, 19(1), $120-127$.

Marshall, F., Dale, D., \& Pilgrim, T. (2004). Delayed-return hunter-gatherers in Africa? Historic perspectives from the Okiek and archaeological perspectives from the Kansyore. In G. Crothers (Ed.), Hunters and gatherers in theory and archaeology, Center for Archaeological Investigations Occasional Paper 21 (pp. 340-375). Carbondale: Southern Illinois University.

Ménard, C., Bon, F., Dessie, A., Bruxelles, L., Douze, K., Fauvelle, F., Khalidi, L., Lesur, J., \& Mensan, R. (2014). Late Stone Age variability in the main Ethiopian Rift: New data from the Bulbula River, ZiwayeShala basin. Quaternary International, 343, 53-68.

Mohammed, M. U., \& Bonnefille, R. (1998). A late Glacial/late Holocene pollen record from a highland peat at Tamsaa, Bale Mountains, south Ethiopia. Global and Planetary Change, 16-17, 121-129.

Negash, A. (1997). Preliminary results of an archaeological reconnaissance of Tigrai, northern Ethiopia. Nyame Akuma, 47, $27-32$.

Negash, A. (2001). The Holocene prehistoric archaeology of the Temben region, northern Ethiopia. Ph.D. dissertation, University of Florida, Gainesville.

Phillipson, D. W. (1977). The excavation of Gobedra Rock Shelter, Axum: An early occurrence of cultivated finger millet in northern Ethiopia. Azania, 12(1), 53-82.

Phillipson, D. W. (1982). The Later Stone Age in sub-Saharan Africa. In Cambridge history Africa volume I: from the earliest times to c. 500 B. C (pp. 410-477). Cambridge: Cambridge University Press.

Phillipson, D. W. (1993). The antiquity of cultivation and herding in Ethiopia. In T. Shaw, P. Sinclair, B. Andah, \& A. Okpoko (Eds.), The archaeology of Africa. Food, metals and towns (pp. 344-357). New York: Routledge.

Phillipson, D. W., Phillips, J. S., \& Tarekegn, A. (2000). Archaeology at Aksum, Ethiopia, 1993-7, vol. 2. British Institute in Eastern Africa.

Pleurdeau, D., Hovers, E., Assefa, Z., Asrat, A., Pearson, O., \& Lam, Y. M. (2014). Cultural change or continuity in the Late MSA/Early LSA of southeastern Ethiopia? The site of Goda Buticha, Dire Dawa area. Quaternary International, 343, 117-135.

Portères, R. (1976). African cereals: Eleusine, Fonio, black fonio, tefi', brachiaria, paspalum, pennisetum, and African rice. In J. H. Harlan, J. M. J. DeWet, \& A. B. L. Stemler (Eds.), Origins of African plant domestication (pp. 409-452). Berlin: De Gruyter Mouton Publishers.

Prendergast, M., \& Lane, P. (2008). Middle Holocene fishing strategies in East Africa: Zooarchaeological analysis of Pundo, a Kansyore shell midden in northern Nyanza (Kenya). International Journal of Osteoarchaeology, 20(1), 88-112.

Purugganan, M. D., \& Fuller, D. Q. (2009). The nature of selection during plant domestication. Nature, 457(7231), 843-848.

Raxter, M. H., Ruff, C. B., Azab, A., Erfan, M., Soliman, M., \& El-Sawaf, A. (2008). Stature estimation in ancient Egyptians:
A new technique based on anatomical reconstruction of stature. American Journal of Physical Anthropology, 136(2), 147-155.

Reid, A., \& Young, R. (2000). Pottery abrasion and the preparation of African grains. Antiquity, 74(283), 101-111.

Robbins, L. H. (1972). Archaeology in the Turkana District, Kenya. Science, 176(4033), 359-366.

Robbins, L. H. (1984). Late prehistoric aquatic and pastoral adaptations west of Lake Turkana, Kenya. In J. D. Clark \& S. A. Brandt (Eds.), From hunters to farmers: The causes and consequences of food production in Africa (pp. 206-211). Berkeley: University of California Press.

Robbins, L. H. (2006). Lake Turkana archaeology: The Holocene. Ethnohistory, 53(1), 71-93.

Ruff, C. B., Trinkaus, E., \& Holliday, T. W. (1997). Body mass and encephalization in Pleistocene Homo. Nature 387, 173-176.

Samberg, L. H., Shennan, C., \& Zavaleta, E. S. (2010). Human and environmental factors affect patterns of crop diversity in an Ethiopian Highland agroecosystem. The Professional Geographer, 62(3), 395-408.

Schmidt, P. R., \& Curtis, M. C. (2001). Urban precursors in the Horn: Early 1st-millennium BC communities in Eritrea. Antiquity, 75(290), 849-859.

Skibo, J. M. (1992). Pottery function: A use-alteration perspective. New York: Plenum.

Skibo, J. M. (2013). Understanding pottery function. New York: Springer.

Tribolo, C., Asrat, A., Bahain, J., Chapon, C., Douville, E., Fragnol, C., Hernandez, M., Hovers, E., Leplongeon, A., Martin, L., Pleurdeau, D., Pearson, O., Puaud, S., \& Assefa, Z. (2017). Across the gap: Geochronological and sedimentological analyses from the Late Pleistocene-Holocene sequence of Goda Buticha, southeastern Ethiopia. PLoS One, 12(1). https://doi.org/10.1371/journal.pone.0169418.

Udpa, N., Ronen, R., Zhou, D., Liang, J., Stobdan, T., Appenzeller, O., Yin, Y., Du, Y., Guo, L., Cao, R., Wang, Y., Jin, X., Huang, C., Jia, W., Cao, D., Guo, G., Claydon, V. E., Hainsworth, R., Gamboa, J. L., Zibenigus, M., Zenebe, G., Xue, J., Liu, S., Frazer, K. A., Li, Y., Bafna, V., \& Haddad, G. G. (2014). Whole genome sequencing of Ethiopian highlanders reveals conserved hypoxia tolerance genes. Genome Biology, 15(2). https://doi.org/10.1186/gb-2014-15-2-r36.

Vavilov, N. I. (1950). Selected writings of N. I. Vavilov: The origins, variation, immunity and breeding of cultivated plants. Translated from Russian by K. Starr Chester. Chronica Botanica 13(1/6). Waltham, MA: Chronica Botanica.

Vigne, J. D. (1997). Iles: vivre entre ciel et mer. Paris: NathanMNHN.

Wana, D., \& Woldu, Z. (2006). Vegetation of Chencha highlands in southern Ethiopia. SINET: Ethiopian Journal of Science, 28(2), 109-118.

Weedman, K. (2002). An ethnoarchaeological study of stone-tool variability among the Gamo hideworkers of southern Ethiopia. In F. Audoin-Rouzeau \& S. Beyries (Eds.), Le Travail du cuir de la préhistoire á nos jours (pp. 131-142). Antibes, France: Éditions APDCA.

Westphal, E. (1975). Agricultural systems in Ethiopia. Center for Agricultural Publishing and Documentation, Wageningen, the Netherlands. 